University of Nebraska - Lincoln

DigitalCommons@University of Nebraska - Lincoln

Papers in the Earth and Atmospheric Sciences

Earth and Atmospheric Sciences, Department

6-2011

\title{
Taxonomic Composition, Paleoecology and Biostratigraphy of Late Cretaceous Diatoms from Devon Island, Nunavut, Canadian High Arctic
}

\author{
Jakub Witkowski \\ University of Warsaw, Poland, jwitkowski@student.uw.edu.pl \\ David M. Harwood \\ University of Nebraska-Lincoln, dharwood1@unl.edu \\ Karen Chin \\ University of Colorado, Boulder, karen.chin@colorado.edu
}

Follow this and additional works at: https://digitalcommons.unl.edu/geosciencefacpub

Part of the Geology Commons, Paleontology Commons, and the Stratigraphy Commons

Witkowski, Jakub; Harwood, David M.; and Chin, Karen, "Taxonomic Composition, Paleoecology and Biostratigraphy of Late Cretaceous Diatoms from Devon Island, Nunavut, Canadian High Arctic" (2011). Papers in the Earth and Atmospheric Sciences. 280.

https://digitalcommons.unl.edu/geosciencefacpub/280

This Article is brought to you for free and open access by the Earth and Atmospheric Sciences, Department of at DigitalCommons@University of Nebraska - Lincoln. It has been accepted for inclusion in Papers in the Earth and Atmospheric Sciences by an authorized administrator of DigitalCommons@University of Nebraska - Lincoln. 


\title{
Taxonomic composition, paleoecology, and biostratigraphy of Late Cretaceous diatoms from Devon Island, Nunavut, Canadian High Arctic
}

\author{
Jakub Witkowski, ${ }^{1}$ David M. Harwood, ${ }^{2}$ and Karen Chin ${ }^{3}$ \\ 1. Department of Historical and Regional Geology, Faculty of Geology, University of Warsaw, \\ ul. Zwirki i Wigury 93, 02-089 Warsaw, Poland; email jwitkowski@student.uw.edu.pl \\ 2. Department of Geosciences, University of Nebraska-Lincoln, P.O. Box 880340, \\ Lincoln, NE 68588-0340, USA; email dharwood1@unl.edu \\ 3. Department of Geological Sciences/Museum of Natural History, UCB 265, University of Colorado, \\ Boulder, CO 80309, USA; email karen.chin@colorado.edu \\ Corresponding author - J. Witkowski, tel 4822 554-0417.
}

\begin{abstract}
Upper Cretaceous sediments of the Kanguk Formation exposed in Eidsbotn and Viks Fiord grabens on Devon Island, Nunavut, Canadian High Arctic, yielded 91 fossil marine diatom species and varieties (including indeterminate taxa), representing 41 genera. Excellent preservation of the assemblages was aided by shallow burial, protection in downfaulted linear grabens, and the presence of abundant volcanic material. Planktonic species and resting spores comprise nearly $70 \%$ of the diatom assemblage, and provided abundant food resources for the Late Cretaceous Arctic ecosystem. Deposition of the approximately $225 \mathrm{~m}$-thick stratigraphic sequence was predominantly in a shallow marine neritic setting, with an upward progression to interbedded terrestrial deposits of the Expedition Fiord Formation, reflecting a regression and eventual persistence of terrestrial facies into the Early Cenozoic. The Kanguk Formation is widespread across the Canadian Arctic, and diatom biostratigraphy indicates a Santonian-Campanian age for the sequences reported herein, based on the presence of Gladius antiquus in the lowermost strata and occurrence of Costopyxis antiqua throughout the succession. However, Amblypyrgus sp. A and Archepyrgus sp. aff. A. melosiroides, encountered in the lower part of the succession, are known exclusively from the Lower Cretaceous. This may suggest a slightly older age. New information on shallow shelf diatom assemblages from this study is compared to reports on two other Late Cretacous Arctic diatom assemblages. These three sites represent an environmental transect from shallow to distal shelf settings and into the oceanic realm.
\end{abstract}

Keywords: fossil marine diatoms, Late Cretaceous, biostratigraphy, paleoecology, arctic, Devon Island

\section{Introduction}

\subsection{Significance of fossil diatoms}

Diatoms are the most diverse group of algae, playing a major role in global carbon and silicon cycles (Kidder and Erwin, 2001; Armbrust, 2009) and inhabiting virtually any environment that provides moisture and sunlight (Mann, 1999). Thus, they offer important information to help reconstruct paleoenvironments and clarify stratigraphic relationships. Their stratigraphic range extends down at least to the Lower Cretaceous (Harwood et al., 2007). Available records list over 20 important Late Cretaceous occurrences of fossil diatoms, including: the Moreno Formation, California (Hanna, 1927, 1934; Nikolaev et al., 2001; Davies, 2006); Gdynia, Poland (Schulz, 1935); Urals and West Siberian Plain (Jousé, 1949, 1951, 1955; Krotov and Schibkova, 1959; Strelnikova, 1966, 1971, 1974, 1975); Alpha Ridge, Arctic Ocean (Barron, 1985; Dell'Agnese and Clark, 1994; Davies, 2006; Davies et al., 2009); Seymour Island, Antarctica (Harwood, 1988); and the islands of the Canadian Arctic (Tapia and Harwood, 2002). These occurrences document a variety of habitats to which diatom taxa were adapted, with specific environmental preferences, morphological features and assemblage characters that can be used to infer variations in paleoenvironmental setting.

The distribution of these assemblages indicates that diatoms were already abundant, widespread and diverse by the end of the Cretaceous (Harwood et al., 2007). Calculations of various authors estimate the number of Cretaceous diatom genera to be around 80 (Harwood and Nikolaev, 1995), and the number of species to exceed 300 (Strelnikova, 1975, 1990; Sims et al., 2006). From one siliciclastic rich, deltaic shelf sequence in the Antarctic Peninsula Harwood (1988) reported nearly 200 diatom taxa. Nevertheless, Cretaceous diatom fossils are generally sparse, and our limited knowledge is mainly due to the temporal instability of the opal-A (Littke et al., 1991) that forms diatom frustrules (Tapia and Harwood, 2002). Fortunately, numerous Cretaceous diatom-bearing deposits are known from polar regions, particularly the Arctic. The often excellent preservation of diatoms in these areas allows to establish a more complete understanding of diatom paleocommunities and biostratigraphic sequences than sites located at lower latitudes, and offers an excellent resource for morphological and taxonomic studies. 


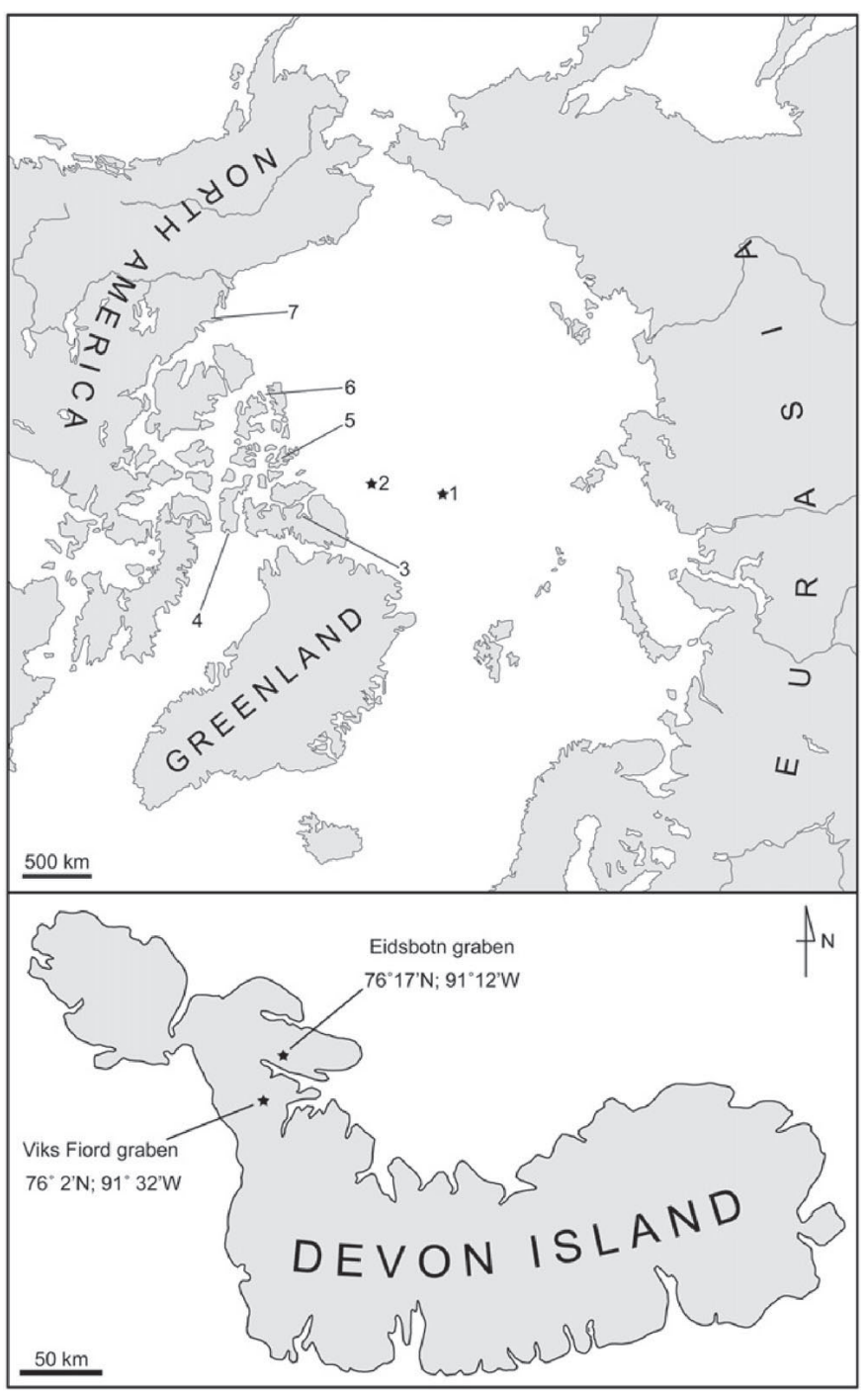

Figure 1. Top: Map of the Arctic showing localities discussed or referred to in this paper. 1 - North Pole; 2 - CESAR 6 site (Alpha Ridge); 3 - Slidre Fiord (Ellesmere Island); 4 - Devon Island; 5 - Hoodoo Dome (Ellef Ringnes Island); 6 - Cape Nares (Eglington Island); 7 Horton River (Northwest Territories). Modified from http://www.dmaps.com. Bottom: Map showing fossil localities at Eidsbotn and Viks Fiord grabens on Devon Island, Nunavut, Canadian High Arctic. Modified from Dyke (1999).

\subsection{Cretaceous Arctic}

Paleoenvironmental conditions in the Arctic during both the Late Cretaceous and the Paleogene differed significantly from those in today's circumpolar areas. Reconstructing Late Cretaceous Arctic paleoenvironments is particularly challenging, however, because there are fewer paleoclimatic proxies than there are for the Cenozoic. Recent successful resolution of seasonal signals from pelagic diatom deposits at the Alpha Ridge in the central Arctic Ocean (Davies, 2006; Davies et al., 2009) demonstrated the potential for diatoms to interpret paleoenvironmental changes. At this site, diatoms occur in interbedded laminae, including vegetative cells and resting spores that reflect seasonal variation. Davies et al. (2009) suggested that a highly stratified water column involving the "fall dump" mechanism (Kemp et al., 2000) caused the continuous high diatom abundance in this region, rather than previously inferred upwelling (Kitchell et al., 1986).
Other successfully applied approaches to interpret Late Cretaceous Arctic paleoenvironments use vertebrate faunas (e.g., Friedman et al., 2003), fossil leaves, and palynology (e.g., Ioannides, 1986; Herman and Spicer, 1996, 1997; Tarduno et al., 1998; Falcon-Lang et al., 2004; Spicer and Herman, 2010). Estimations of terrestrial mean annual temperatures range from below $10{ }^{\circ} \mathrm{C}$ to as high as $18-20{ }^{\circ} \mathrm{C}$ for different parts of the Late Cretaceous Arctic (Herman and Spicer, 1997; Friedman et al., 2003; Spicer and Herman, 2010; Tomsich et al., in press). While recent reconstructions indicate that winter marine water temperatures in the Late Cretaceous enabled at least temporary ice formation (Davies et al., 2009), mean temperatures as high as $15^{\circ} \mathrm{C}$ have also been suggested for the surface waters of the Arctic Ocean (Jenkyns et al., 2004). There is still considerable discussion regarding Cretaceous Arctic temperatures through time, the nature of the meridional temperature gradient, and whether the Cretaceous Arctic ever hosted seasonal or year-round ice (e.g. Hay, 2008; Stein, 2008).

In terms of paleogeography, the Late Cretaceous Arctic Ocean was largely isolated by surrounding land masses, but paleobiogeographic evidence (including distributions of diatoms) indicates the existence of shallow marine connections between lower latitude waters and the otherwise land-locked Arctic Ocean, through the Western Interior Seaway and Turgai Strait (Magavern et al., 1996; Baraboshkin et al., 2003).

\subsection{Aim of the present paper}

Exploration of Devon Island in 1998 and 2003 revealed a variety of macrofossils in the Kanguk and overlying Expedition Fiord formations, including body fossils from invertebrates and vertebrates, plus abundant coprolites (Chin et al., 2008). Subsequent analyses of sediments from these sequences have identified considerable concentrations of exceptionally well-preserved biosiliceous remains, including the diatoms reported here, as well as silicoflagellates (McCartney et al., in press). Chin et al. (2008) used a multidisciplinary approach including palynology and geochemistry to study the recovered taphocenosis, and considered trophic relationships and community structure (from primary producers through top predators) through the examination of coprolites. The present paper complements the findings of Chin et al. (2008), and (1) describes the fossil diatoms from these deposits, (2) discusses their taxonomic composition, and (3) provides information on their paleoecology and biostratigraphic sequence. This information improves our understanding of the paleoenvironmental and geological history of the Upper Cretaceous Kanguk Formation in this area. We consider new information from this assemblage within the context of diatoms from other deposits of comparable age. These assemblages represent habitats ranging from shallow shelf settings to deeper shelf and oceanic settings in the Cretacous Arctic Ocean basin (Tapia and Harwood, 2002; Davies, 2006; Davies et al., 2009).

\section{Study area and geological setting}

Devon Island is a large, uninhabited island in the eastern portion of the Canadian Arctic, located west of central Greenland and south of Ellesmere Island, between $74^{\circ}$ and $77^{\circ} \mathrm{N}$ latitude and $79^{\circ}$ and $97^{\circ} \mathrm{E}$ longitude (Figure 1). Studies of Cretaceous outcrops throughout the Canadian Arctic Archipelago by the Geological Survey of Canada (Fortier et al., 1963; Miall, 1979, 1991; Embry, 1991) have shown that sediments on Devon Island represent deposition at the southern margin of the Sverdrup Basin; these deposits are part of the Arctic Platform, a thick succession of Lower Paleozoic strata that are capped unconformably by $\sim 700 \mathrm{~m}$ of Mesozoic and Paleogene non-marine and 
marine clastic rocks (Tozer, 1961). The Cretaceous represents a remnant of the trangressive Mesozoic sedimentary cover that was removed by uplift, faulting and erosion during the Paleogene stages of development of the Sverdrup Basin (Thorsteinsson and Mayr, 1987; Ricketts and Stephenson, 1994). This region was further eroded by subsequent glacial excavation during the Late Cenozoic (Dyke, 1999). Mesozoic sediments of the marine Kanguk Formation (Cenomanian-Campanian), which is widespread across the Canadian margin (Embry, 1991; Ricketts and Stephenson, 1994; Núñez-Betelu et al., 1995a, 1995b; Tapia and Harwood, 2002), and the overlying terrestrial Expedition Fiord Formation (Maastrichtian-Lower Paleocene) are preserved locally on Devon Island in fault-bounded troughs within Eidsbotn and Viks Fiord grabens (Mayr et al., 1998) (Figure 2). Paleogeographic reconstructions show that toward the end of the Cretaceous, present-day islands of the Canadian Arctic lay less than $10^{\circ}$ south of their present locations (Tarduno et al., 1998), within the Arctic Circle.

Samples for this study were collected from eight measured sections (Figure 2; Figure 3). The approximately 225 m-thick Eidsbotn composite section is a conformable regressive sequence comprising $\sim 140 \mathrm{~m}$ of dark, marine biosiliceous mudstones overlain by $\sim 75 \mathrm{~m}$-thick beds of greensand and terrestrial mudstones with coal intercalations. The greensand beds host numerous layers of bentonite, which allow local correlation between the sections (Bloch et al., 2004; Figure 2). Initial age control for the Cretaceous sequences on Devon Island was provided by the occurrence of the palynomorphs Translucentipolis plicatilis Chlonova and Wodehouseia edmontoniacola Wiggins (Chin et al., 2008), which suggest a Campanian age (Lerbekmo and Braman, 2002).

The large-scale formation of glaucony (up to $75 \mathrm{~m}$ ) at both Devon Island sites (Bloch et al., 2007; Chin et al., 2008) suggests shelfal, low energy conditions coupled with high biological activity (see the study of a Cretaceous glauconitic sequence in ODP Site 748, Bitschene et al., 1992). The process of glaucony formation is observed in modern oceans (Rao et al., 1995) as an outcome of a halmyrolysis process in conditions of low terrigenous input, below $50 \mathrm{~m}$ depth (Chafetz, 2007). Glauconite can also form as a result of diagenetic changes, including replacement of biosiliceous remains (Borkowska and Smulikowski, 1973).

Considering the time and low terrigenous input necessary for formation of the thick glaucony complexes on Devon Island, continuous subsidence over an extended period is inferred (J. D. Bloch, personal communication). A fluctuating paleoenvironmental setting is deduced for the Viks Fiord graben locality, where marine mudstones are interbedded with terrestrial sediments containing coal intercalations in facies transitional between the Kanguk and Expedition Fiord formations (Viks Fiord north composite section, Figure 3). Although there are similarities between the Eidsbotn and Viks Fiord successions, Viks Fiord appears to have been located in a shallower setting. In addition, fewer macrofossils were recovered from Viks Fiord graben.

Terrestrial sediments are also present in the uppermost portion of the Eidsbotn graben composite section, as indicated by the presence of coal intercalations, fossil root systems, coalified conifer wood, and terrestrial palynomorphs. Conifer forests have been reported from other Late Cretaceous Arctic localities as well (e.g., Falcon-Lang et al., 2004).

A rich, composite suite of macro- and microfossils from the Devon Island sections was used to reconstruct a Late Cretaceous paleocommunity (Chin et al., 2008), including plesiosaur and bird bones, fish teeth and bones, inoceramid and lingulid shells, crustacean carapaces, sponges, pollen, dinoflagellate cysts, radiolarians, silicoflagellates and the marine diatom flora reported herein. The diatoms were originally identified in thin sections of coprolite samples, presumed to have come from large vertebrates.

\section{Materials and methods}

Fifty-three sediment samples were collected during the 2003 field season. These samples are from the measured stratigraphic sections and are irregularly spaced (Chin et al., 2008). Samples were collected from below the slumped surface layer associated with freeze-thaw cycles. Stratigraphic positions of samples are indicated in Figures $2 \& 3$.

Chemical breakdown of the sediment was conducted in new $175 \mathrm{ml}$ beakers (in order to prevent contamination with other material). Samples were broken into small fragments of 2-3 mm diameter, and treated in successive baths of $\mathrm{HCl}$ $(\sim 10 \%)$ and $\mathrm{H}_{2} \mathrm{O}_{2}(\sim 37 \%)$, followed by washes in distilled water of not less than $6 \mathrm{~h}$ in duration. Diatoms were concentrated by decantation and removal of coarse clastic material. Residues were stored in plastic vials and protected from fungal growth by the addition of a few drops of formaldehyde. Slides were prepared by drying the residues onto $18 \times 18 \mathrm{~mm}$ coverslips that were then mounted onto glass slides with Naphrax optical adhesive.

Light microscope examination of the slides was performed by means of a Leica DMLB microscope. A sample was considered barren if less than 5 identifiable diatom valves were found in 2 transects (ca. 144 fields of view at magnification $\times 1000)$ through the center of a coverglass. Two slides were counted for every diatom-bearing sample. Approximately 400-500 diatom valves were counted on each slide. Valve counting protocol followed the method of Schrader and Gersonde (1978), and numerical results are presented in Table 1.

Light photomicrographs were taken with a Nikon DS-2 digital camera and subsequently processed in Adobe Photoshop. Scanning electron microscope (SEM) examination was conducted with a Hitachi S-4500 microscope at Johann-Wolfgang Göthe University in Frankfurt am Main, Germany.

The following publications provided the principal reference for identifying the Late Cretaceous diatoms recovered from the Devon Island samples: Schmidt et al. (1874-1959), Pantocsek (1886, 1889), Strelnikova (1974), Hajós and Stradner (1975), Barron (1985), Harwood (1988), Dell'Agnese and Clark (1994), Tapia and Harwood (2002), and Davies (2006). Authorship of diatom taxa reported herein is given in Table 1, along with valve counting data. Consult the taxonomic list in Appendix 1 (Supplementary Material) for synonymy of taxa and comments.

\section{Results}

\subsection{General taxonomic composition}

Identifiable and sufficiently abundant diatoms are present in 15 of 53 samples examined. Moderate to well-preserved diatom valves (for an overview of preservation states see Figure 4) were identified in 11 samples from Eidsbotn graben (1 sandstone, 4 mudstone and 6 bentonite samples). Specimens are considered well-preserved if they retain delicate structures such as vela (Figure 4A), linking spines, outer and inner openings of processes, and girdle bands. In moderately preserved specimens the valve outline enables identification, but some breakage and/or dissolution of fragile valve structures is observed (Figure 4B). Samples collected at Viks Fiord graben show poorer preservation states; out of four diatom-bearing samples from mudstone beds, only sample VF0102 contains well-preserved diatoms. The remaining samples yielded etched and highly fragmented material (Figure 4C), showing signs of diagenetic change or redeposition, and are regarded as poorly preserved. As a result, many diatoms in these samples can be identified only to the generic level.

A total of 91 diatom taxa belonging to 41 genera were identified. Of these, four taxa were recognized as representing pre- 
composite section

(sections 1, 4 and 5)
S
N

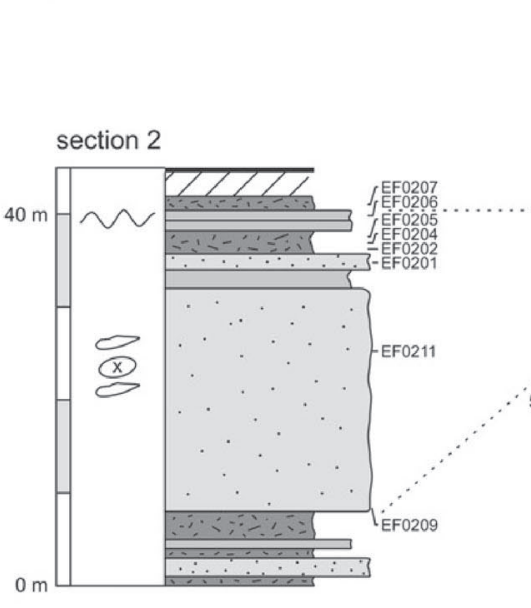

section 3

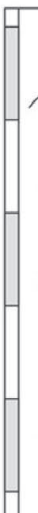

?

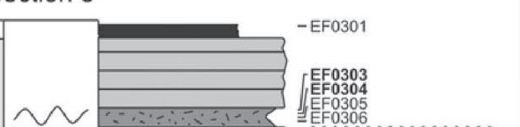

$0 \mathrm{~m}$

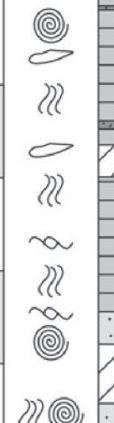

《(e)

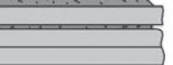

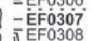

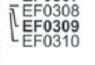

$200 \mathrm{~m}$
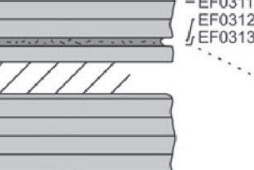

品

(5)
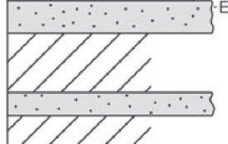

$\because \ddots$
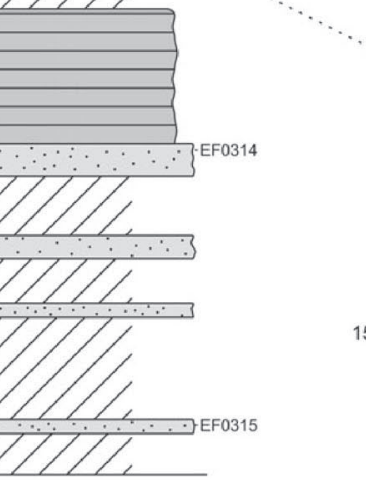

Explanations

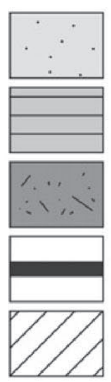

glauconitic sandstones

mudstones

bentonites

coal

slumped surface layer; lithology unknown
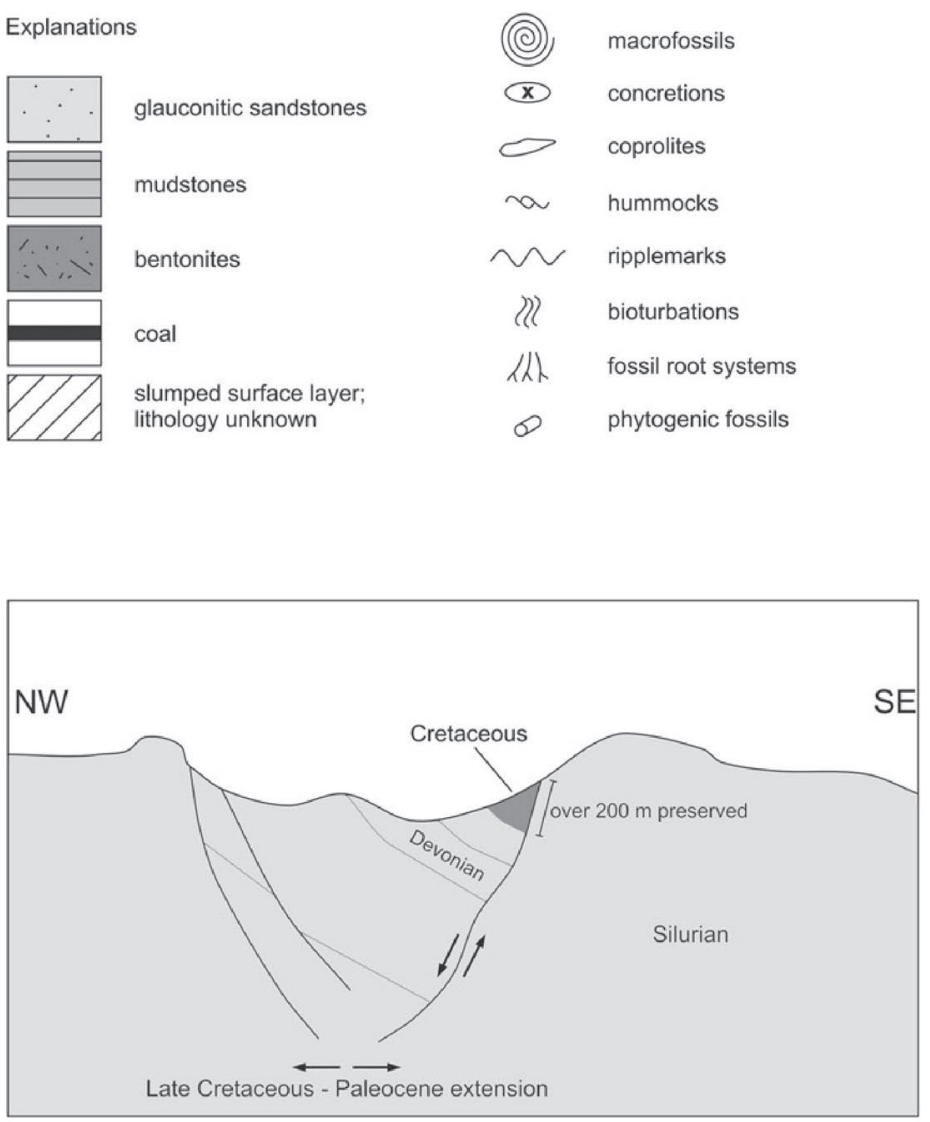
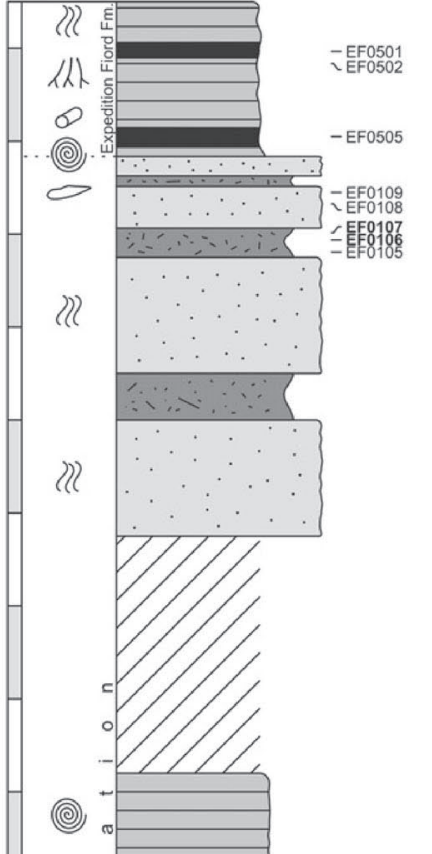

?)

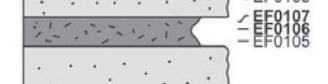

??

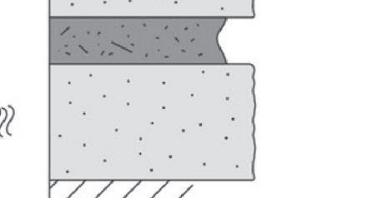

-EF0103

-EF0104

??

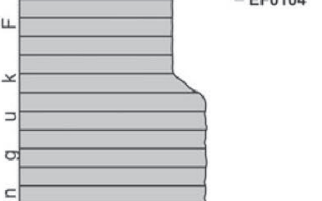

-EF0102

EF0402

- EF0401

Figure 2. Stratigraphic columns representing sections measured in Eidsbotn graben. Datum for correlation is the base of the uppermost bentonite layer. Stratigraphic position of samples examined in this study, as well as the distribution of macrofossils, are indicated. Diatom-bearing samples are indicated in bold font. The frame in the lower left corner shows a simplified diagrammatic section of the geological setting of the studied deposit; a rotated, downfaulted block preserves a remnant of Cretaceous sediments within Paleozoic deposits (modified from Mayr et al., 1998, p. 248 , following J.D. Bloch, personal communication). 
$\mathrm{N}$ north composite section

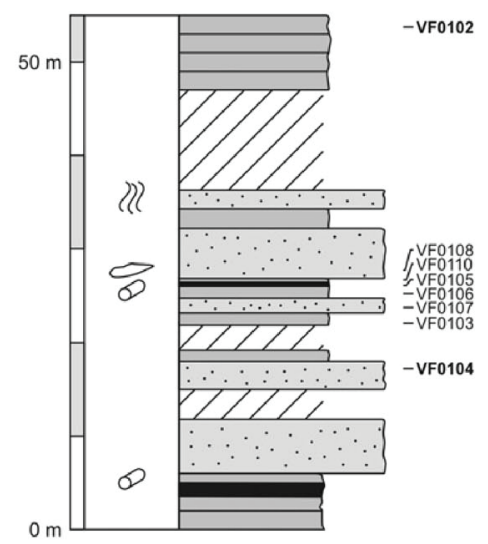

S

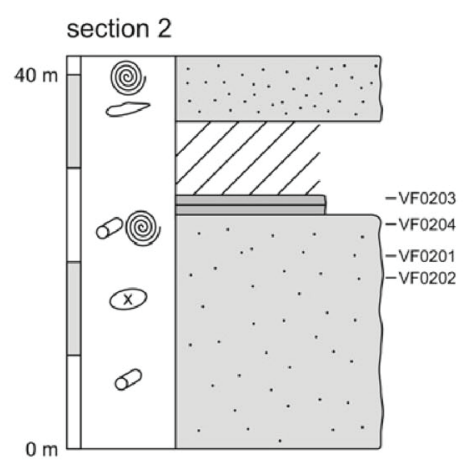

Figure 3. Stratigraphic columns representing sections measured in Viks Fiord graben and the position of samples examined in this study as well as the distribution of macrofossils. Diatom-bearing samples are indicated in bold font. For explanations see Figure 2.

viously unknown genera and species (Figure 13), and will receive appropriate attention in separate publications. Centric diatoms constitute $97 \%$ of the identified taxa. Pennate diatoms are represented by only three species belonging to two araphid genera: Incisoria and Sceptroneis.

The terms "environmental assignment" or "environmental preferences" used below refer to whether a discussed species shows planktonic, tychoplanktonic or benthic characteristics, or whether it is considered a resting spore; these environmental preferences are used to identify ecological groups. Planktonic and probable planktonic diatoms dominate the studied assemblage $(38.5 \%$ by number of species, $51.5 \%$ by abundance). Resting spores also indicate the presence of planktonic taxa and account for nearly $30 \%$ of the species (abundance: $33.1 \%$ ). Probable tychoplanktonic diatoms are the least diverse ecological group in the studied community, comprising $7.7 \%$ of the identified taxa ( $9.8 \%$ abundance). Species identified as benthic forms account for $15.4 \%$ of the total number of species (1.6\% abundance). No environmental assignment is made for the remaining $8.8 \%$ percent of taxa $(4 \%$ by abundance). The majority of taxa encountered in the Upper Cretaceous strata of Devon Island represent extinct genera. Approximately one-third of the genera present in the studied material are extant: Actinoptychus, Aulacodiscus, Coscinodiscus, Hemiaulus, Hyalodiscus, Paralia, Proboscia, Pseudopodosira, Rhizosolenia, Sceptroneis, Sheshukovia, Stellarima and Stephanopyxis.

The assignment of environmental preferences to extinct species is difficult. In several cases, judgements are based on morphological features (adaptations for suspension in the water column or the presence of processes for attachment), chain formation, geographical distribution, and associated taxa in other assemblages. If possible, individuals were compared to extant species of the same genus. The groups of diatoms assigned to different environmental preferences are discussed below in order of abundance. Relative abundances of the taxa plotted against their stratigraphic occurrences are summarized in Figure 5.

All samples are dominated by planktonic diatoms and resting spores, although their percentages vary in each sample. Treated together, these two groups constitute as much as $68.1 \%$ of the total number of taxa, representing $84.7 \%$ of the community in terms of abundance. The lowest abundances of planktonic forms are exhibited by samples EF0402 (20.7\%), EF0401 (22.4\%), and VF0305 (20.4\%). In contrast, planktonic diatoms are the most abundant in samples collected from bentonite beds, particularly EF0303 and EF0304 (74.7\% and 67.4\%, respectively).

The highest abundance of tychoplanktonic diatoms is observed in sample EF0402 (32.7\%), whereas sample EF0304 shows the lowest relative abundance of tychoplanktonic forms, equal to $0.41 \%$. Benthic diatoms reach the highest abundances in samples collected from the upper part of the studied section (samples EF0106 and EF0107, 3.95\% and 3.85\% respectively). This is consistent with the general interpretation of the studied section as a regressive sequence. Valves belonging to taxa of unknown environmental preferences are abundant in samples collected from the lowermost strata in the section (sample EF0401, 3.6\%), and in samples collected from bentonite beds (specimens of an indeterminate genus reach an abundance of $21.4 \%$ in sample EF0304).

Stratigraphic ranges of selected taxa and relative abundances of environmental groups in individual samples are presented in Figure 5. The Eidsbotn graben composite section and Eidsbotn section 3 are plotted separately, because biostratigraphic and lithostratigraphic correlations between the sections are tentative. Viks Fiord north composite section and Viks Fiord section 3 are plotted in stratigraphic order. A few species are present in all studied samples: Cortinocornus rossicus (Figure 8A-E, H, R, S; Figure 12A-D), Costopyxis antiqua (Figure 7G; Figure 11L), Costopyxis schulzii f. ornata (Figure 11J), C. schulzii (Figure 7E, F, M, N; Figure 11K), Hemiaulus asymmetricus (Figure 8K, L) and Hemiaulus polymorphus (including $H$. polymorphus var. frigida; Figure 9L, M).

\subsection{Environmental preferences of the identified taxa}

\subsubsection{Planktonic and probable planktonic taxa}

This most common group of diatoms in the studied material includes 35 taxa (38.5\% of total number of taxa, $51.5 \%$ by abundance), belonging to 13 genera: Briggera, Cortinocornus, Coscinodiscus, Gladiopsis, Gladius, Hemiaulus, Proboscia, Sphynctolethus, Stephanopyxis, Thalassiosiropsidella, Thalassiosiropsis, Trinacria and Trochosiropsis. The most abundant taxa are discussed below.

Hemiaulus is a common Cretaceous and Paleogene taxon and is represented by the largest number of species (14 species and 1 variety) in the studied material. Its most common representatives are: Hemiaulus antiquus (31.6\% of valves counted in sample EF0304; Figure 8O, P; Figure 12H, I) and H. asymmetricus (29\% of valves counted in sample EF0307). Hemiaulus species are present in all diatom-bearing samples from Devon Island, although their relative abundance varies. The fewest representatives of this genus occur in samples VF0303, VF0305 and VF0104 (three to four species), most likely due to the poor state of preservation. In well-preserved samples the number of Hemiaulus species ranges from 4 (sample EF0102) to 12 (sample EF0107).

Cortinocornus is also a common genus in the studied material. C. rossicus is the second most abundant taxon, and is represented by two basic morphotypes: the first morphotype 


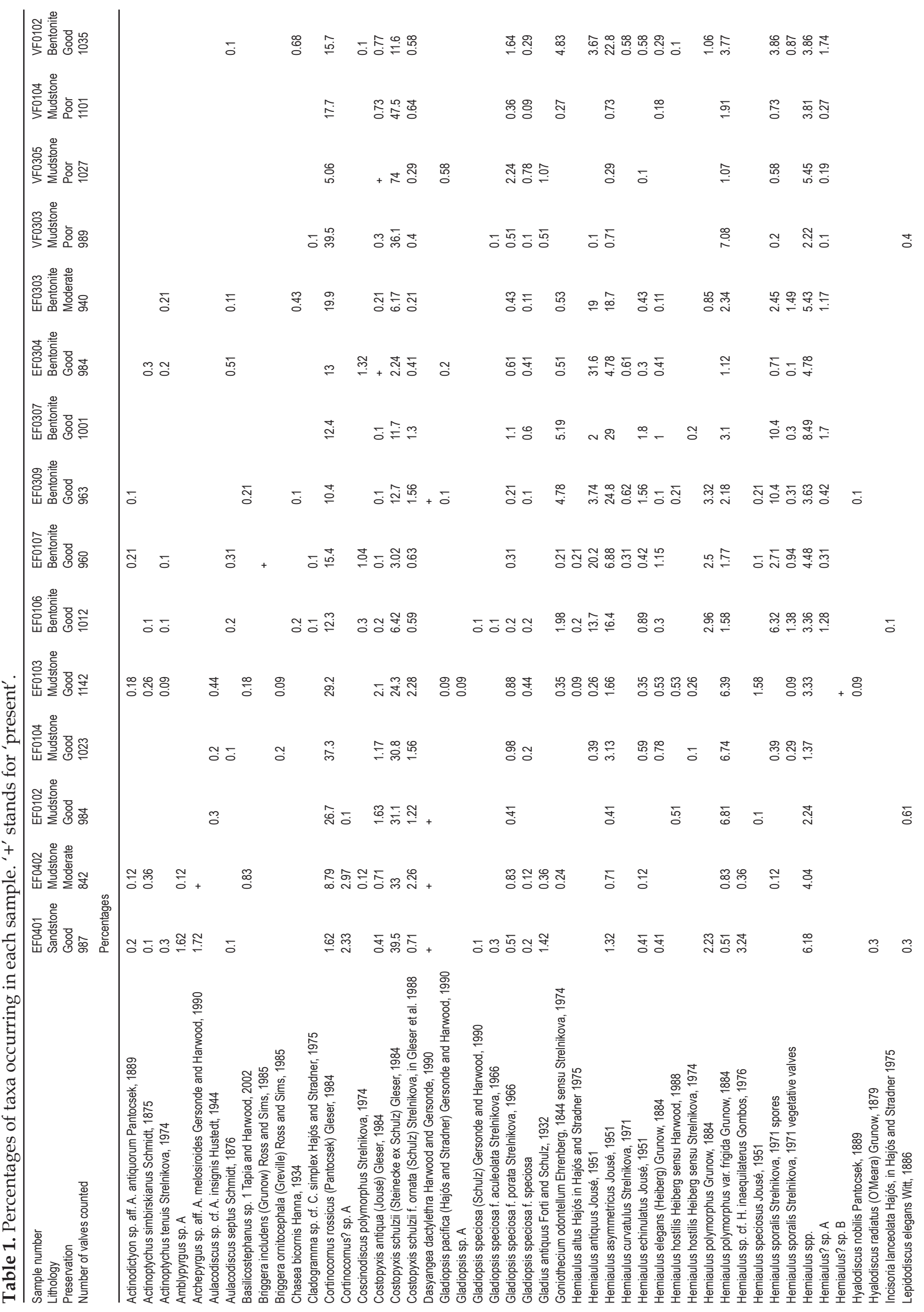




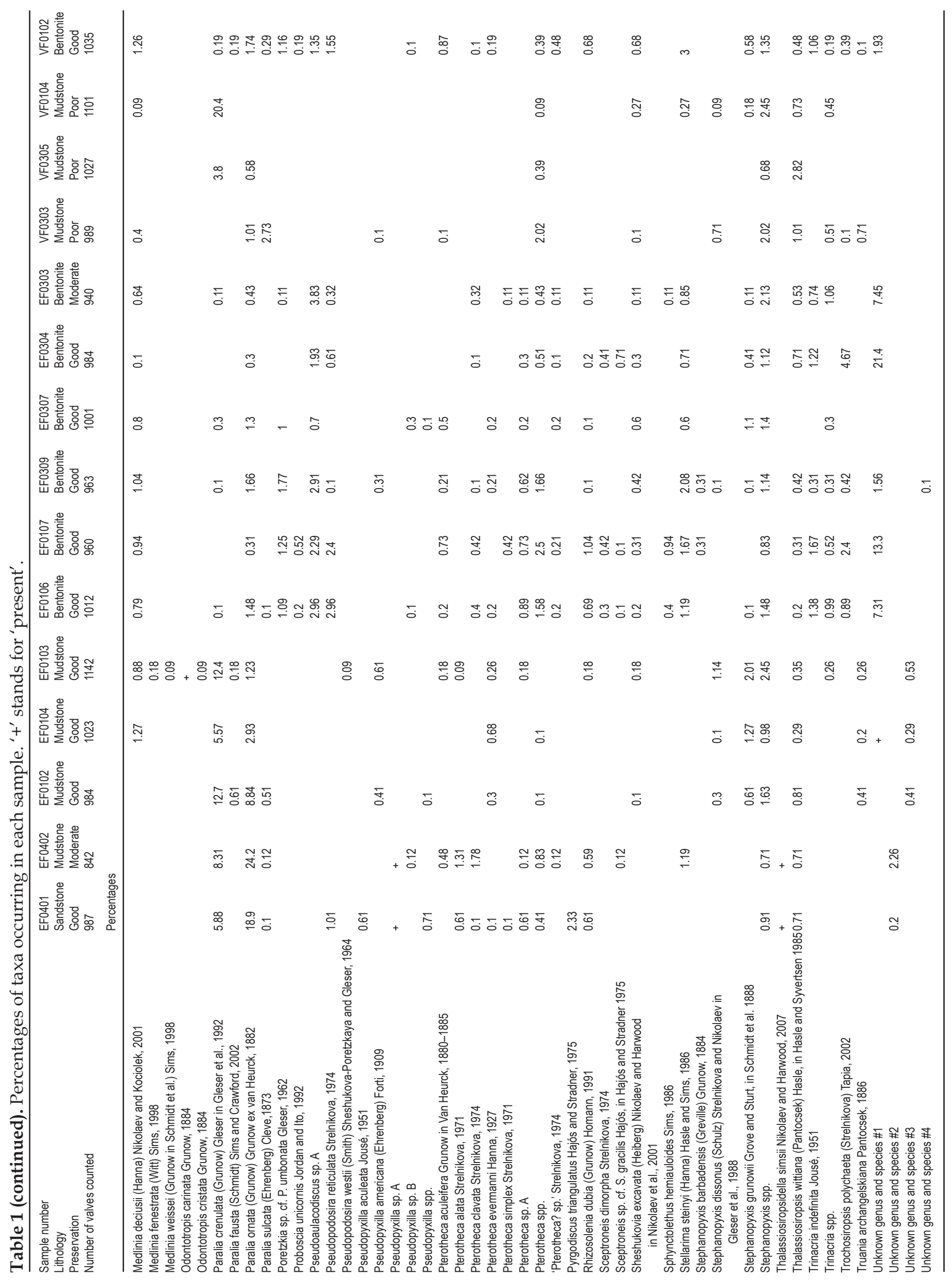



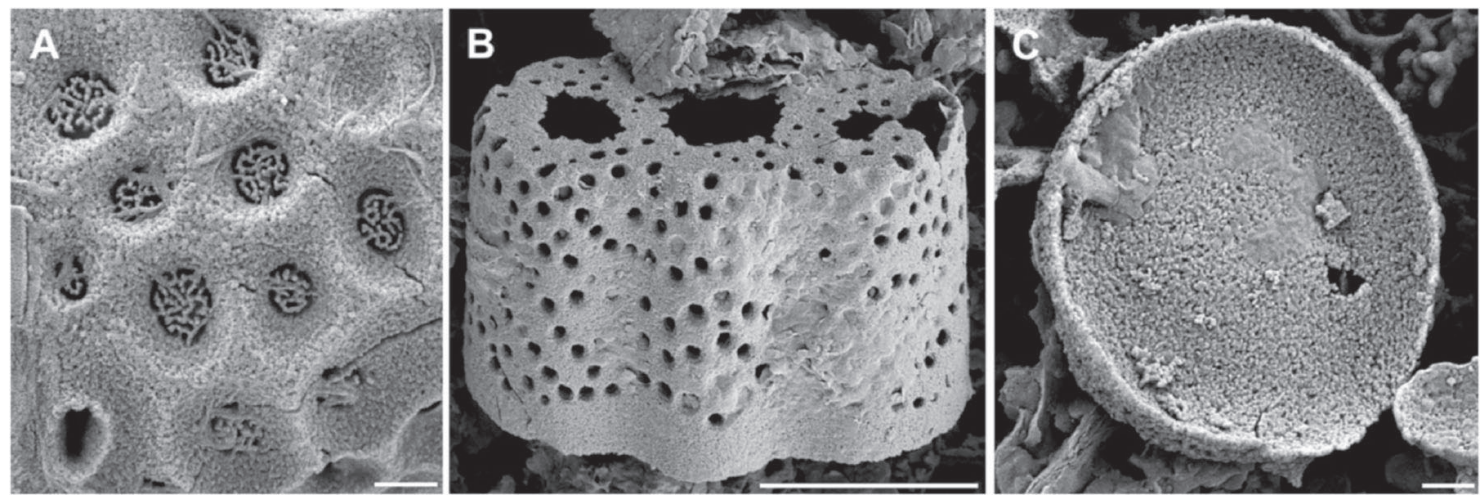

Figure 4. Comparison of preservation states observed in the studied material. A. Good preservation: detail of a Cortinocornus rossicus (second morphotype) valve, showing almost intact cribra, and the external opening of a rimoportule (lower left). Scale bar $=1 \mu \mathrm{m}$, sample EF0304. B. Moderate preservation: broken valve of Cortinocornus? sp. A. Scale bar $=10 \mu \mathrm{m}$, sample EF0402. C. Poor preservation: unknown genus and species. Scale bar $=1 \mu \mathrm{m}$, sample EF0402.

(Figure 8A, B, H, R, S; Figure 12A, B) resembles specimens described by Strelnikova (1974), and the second morphotype (Figure 8C-E; Figure 12C, D) is similar to specimens illustrated by Jousé (1951) and Harwood (1988). An additional taxon is tentatively identified as Cortinocornus? sp. A (Figure 8F, M, N; Figure 12E). The prevalence of Cortinocornus in neritic sediments, as well as its global geographic distribution (Strelnikova, 1974; Ross et al., 1977; Harwood, 1988) suggests a planktonic habit. Species of Cortinocornus exhibit stratigraphic potential: (1) valves of Cortinocornus? sp. A occur only in the lowermost portion of the studied section, (2) the first morphotype of $C$. rossicus is most common in the middle interval of this section, and (3) the second morphotype is associated mostly with samples collected toward the top of the suc- cession. Ross et al. (1977) estimated the stratigraphic range of C. rossicus as Upper Cretaceous to Upper Paleocene (possibly Lower Eocene).

Stephanopyxis is present in all diatom-bearing samples, although less abundant than Hemiaulus or Cortinocornus (not more than 2\% for each species). Stephanopyxis dissonus (Figure 11G) and Stephanopyxis grunowii (Figure 11H) are the most common species of the genus identified in the Devon Island samples, and are regarded as vegetative cells.

Occurrences of Gladiopsis are restricted to Cretaceous strata (Harwood and Nikolaev, 1995), and the following species are present in the Devon Island material: Gladiopsis pacifica, Gladiopsis speciosa (Figure 7S; Figure 11C), and Gladiopsis sp. A (Figure $10 \mathrm{H})$. In addition, three formae distinguished within $G$.

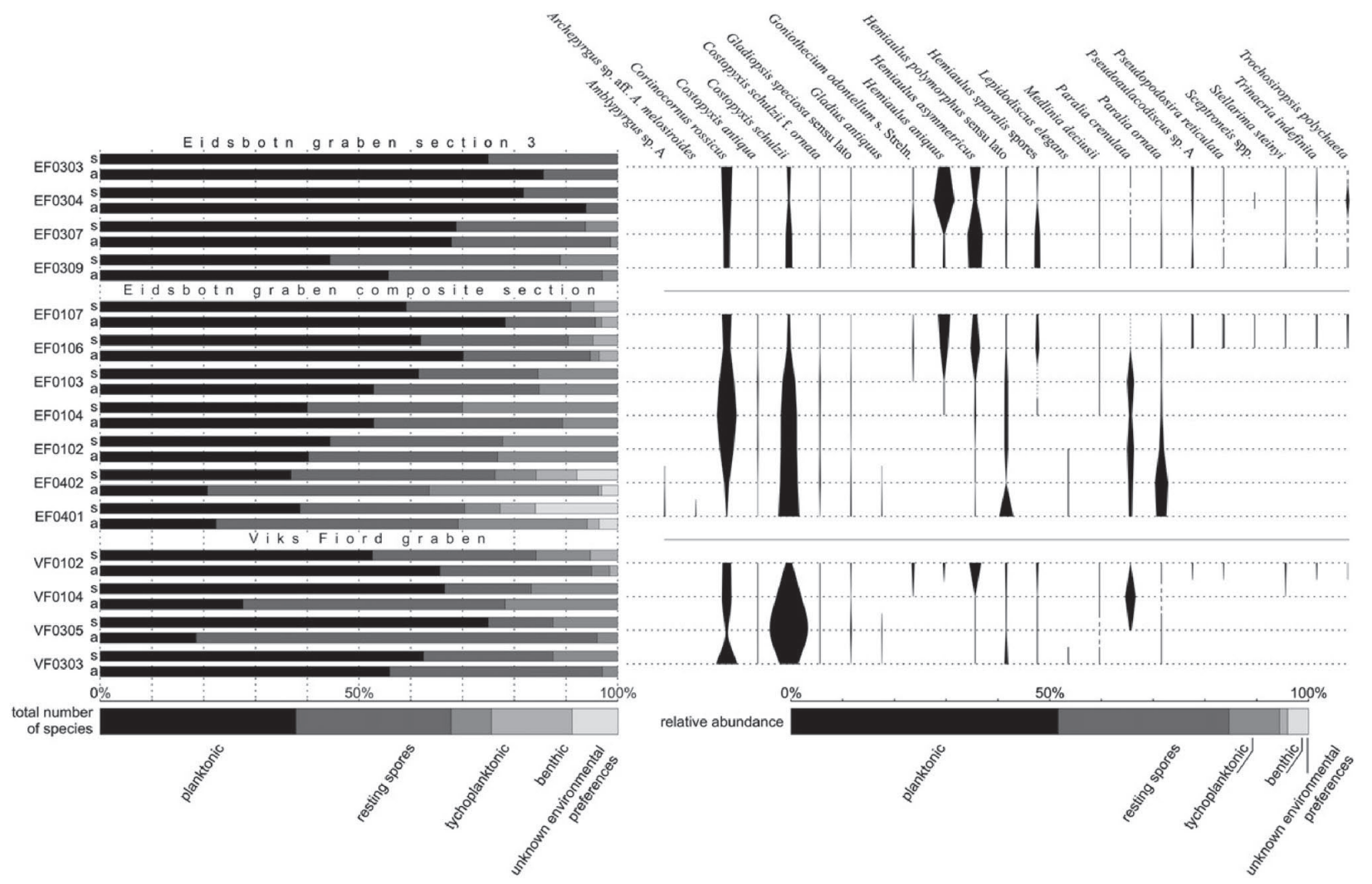

Figure 5. Diagram showing total taxonomic composition of the studied communities expressed as percentage of individual ecological groups by number of species (lower left) and by relative abundance (lower right), and taxonomic composition of each sample, expressed by number of species percentage (s) and relative abundance (a). The right column shows stratigraphic occurrences of selected taxa plotted against their relative abundance in every sample. Note that Viks Fiord graben, Eidsbotn graben composite section, and Eidsbotn graben section 3 are plotted individually. 

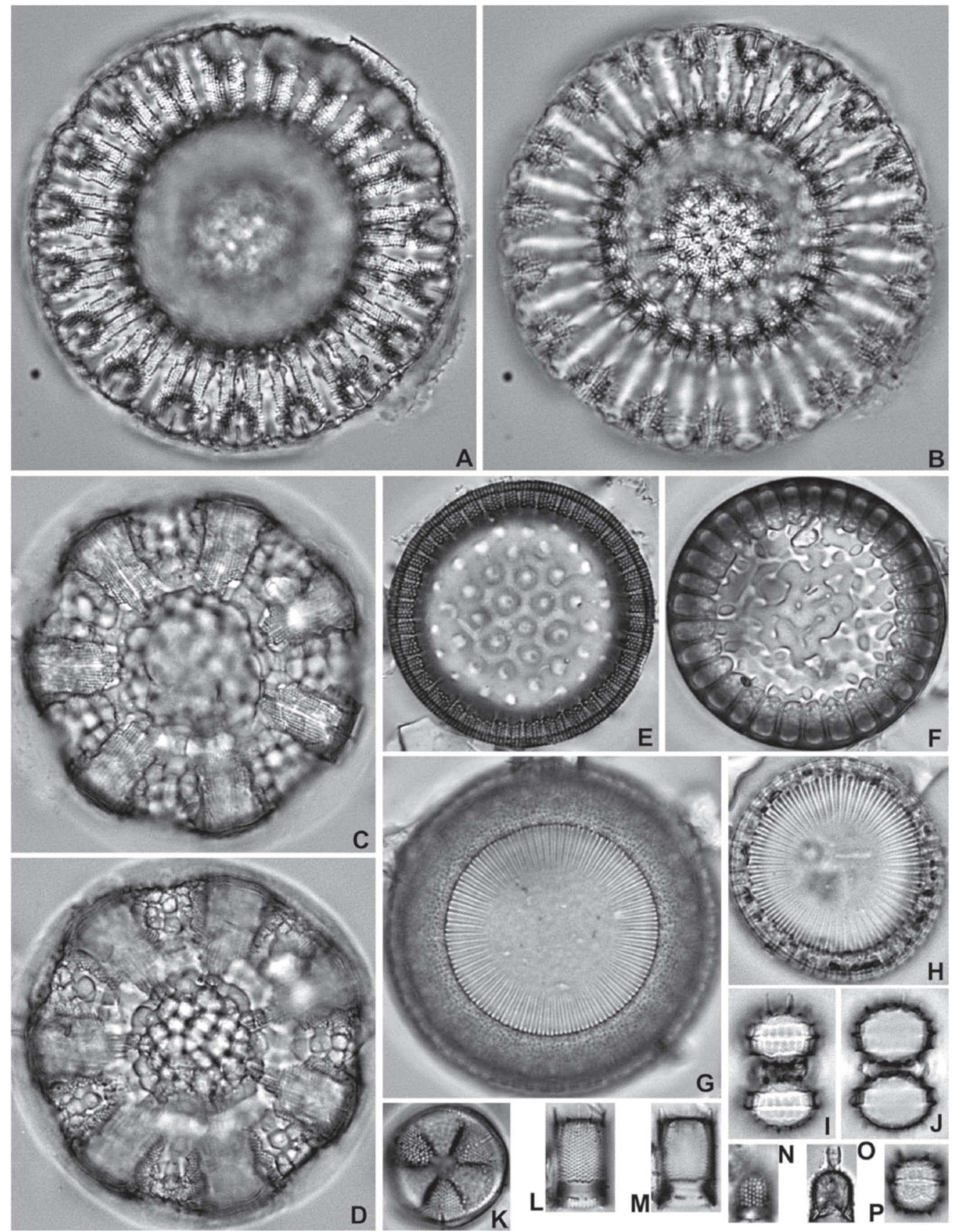

C
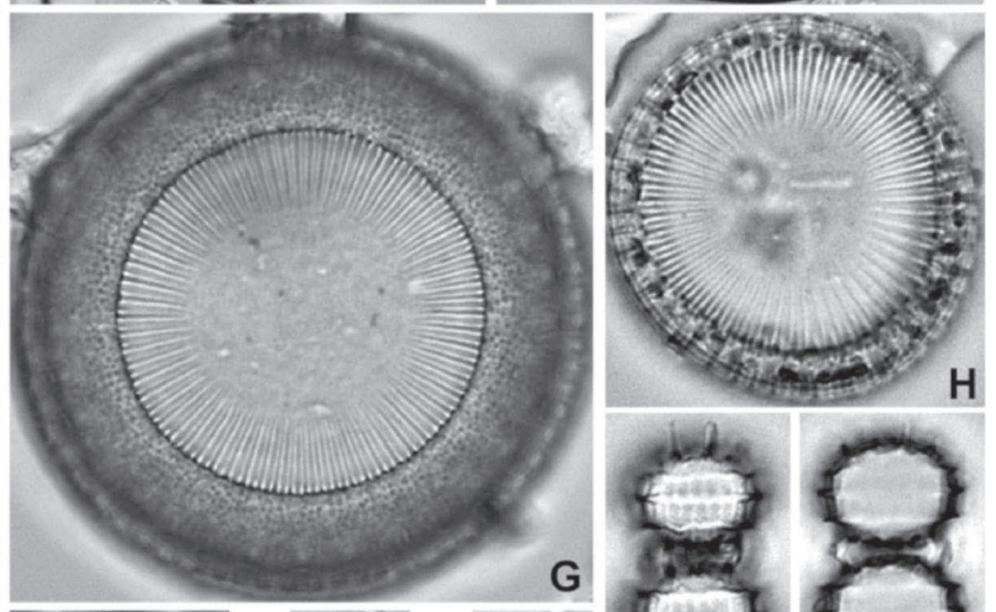

D
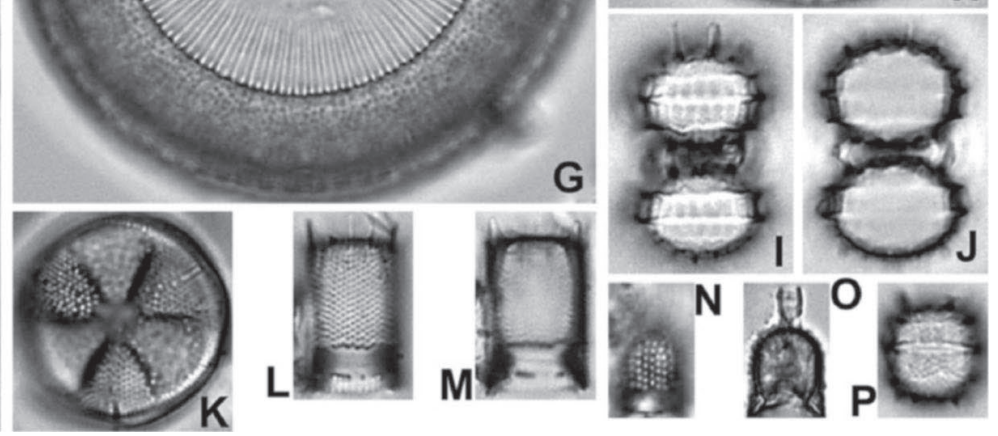

Figure 6. Light Microscope (LM) photomicrographs of diatoms from Devon Island. Magnification $\times 1500$. A and B. Lepidodiscus elegans Witt, sample EF0103. Valve view. High and low focus of the same specimen. C and D. Actinodictyon sp. aff. A. antiquorum Pantocsek, sample EF0103. Valve view. High and low focus of the same specimen. E. Paralia ornata (Grunow) Grunow ex van Heurck, sample EF0103. Valve view. F. Truania archangelskiana Pantocsek, sample EF0102. Valve view. G. Paralia fausta (Schmidt) Sims and Crawford, sample EF0102. Valve view. H. Paralia sulcata (Ehrenberg) Cleve, sample VF0102. Valve view. I and J, P. Pseudopodosira reticulata Strelnikova. I and J - sample EF0106, chain of two cells in girdle view. High and low focus of the same specimen. P - sample EF0107, frustule in girdle view. K. Actinoptychus tenuis Strelnikova, sample EF0304. Valve view. L and M. Archepyrgus sp. aff. A. melosiroides Gersonde and Harwood, sample EF0401. Girdle view. High and low focus of the same specimen. N and O. Amblypyrgus sp. A, sample EF0402. Girdle view. High and low focus of the same specimen. 

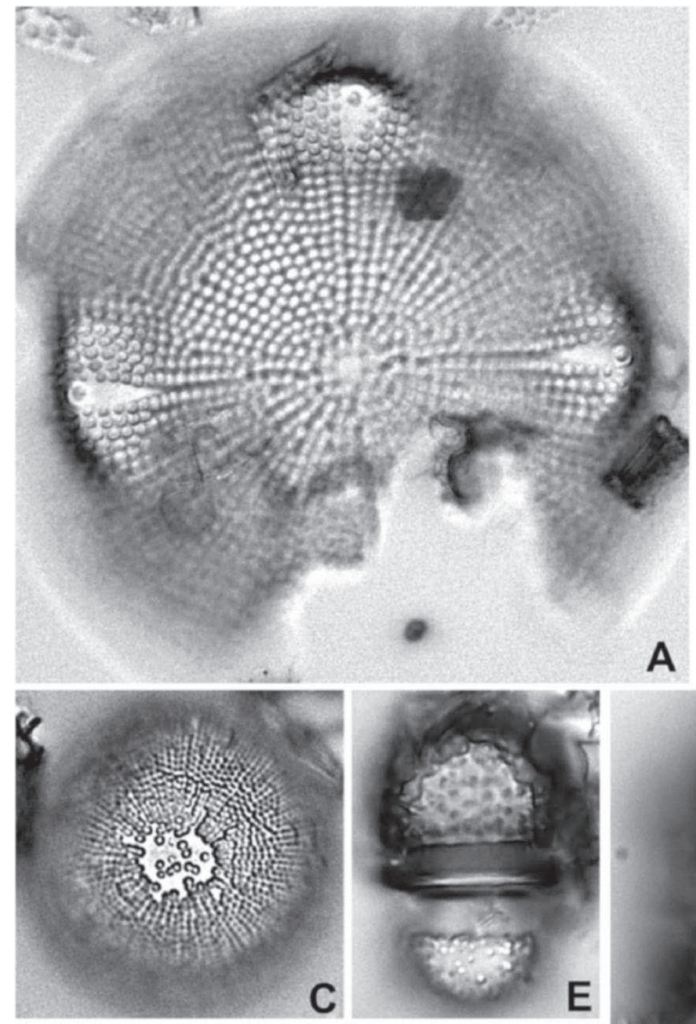

A
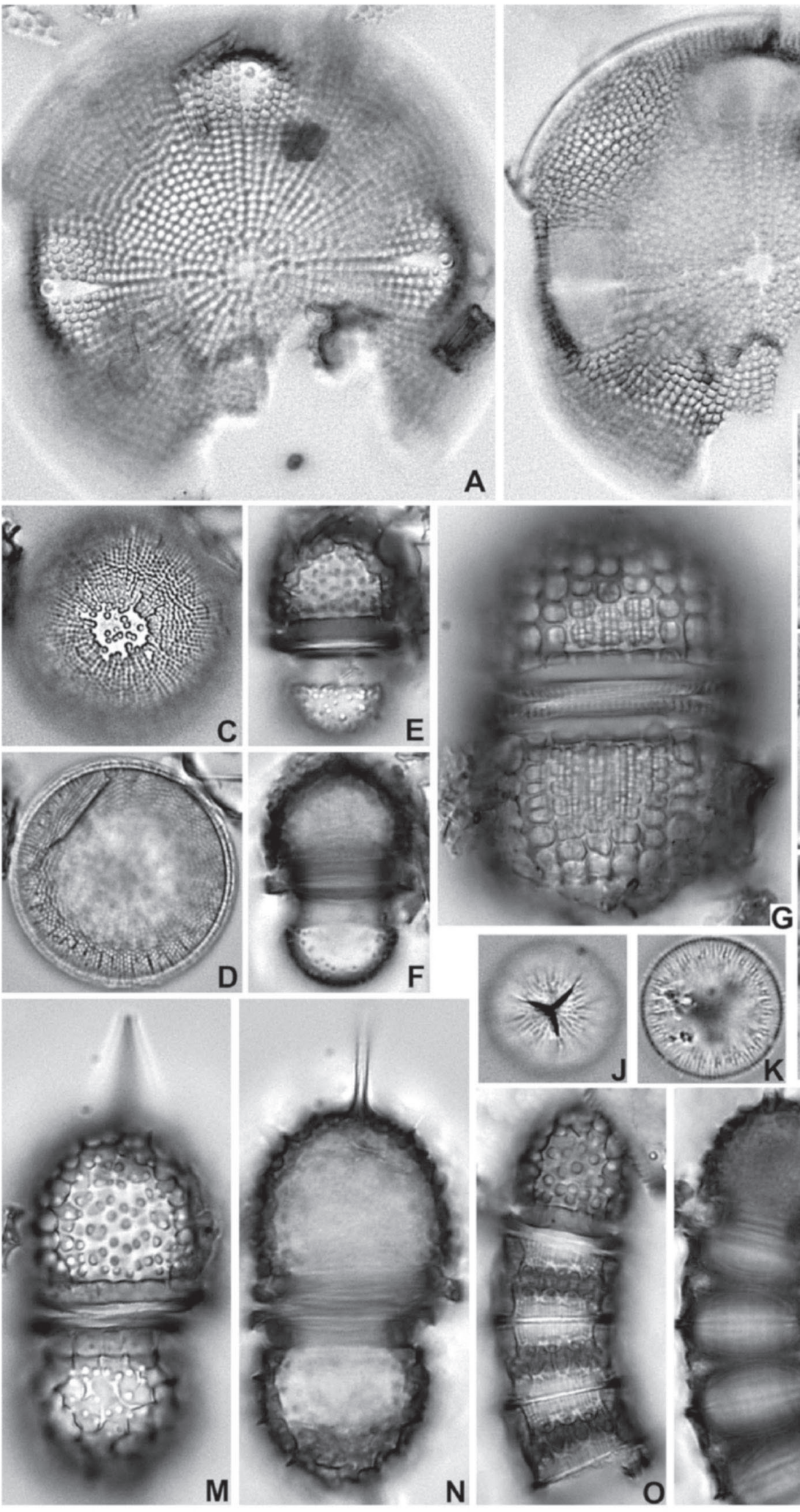

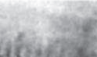
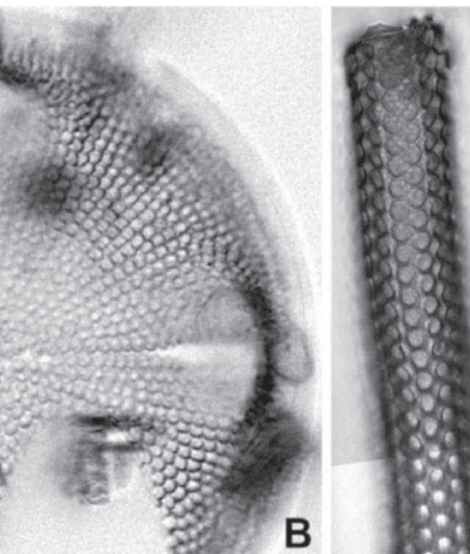

S

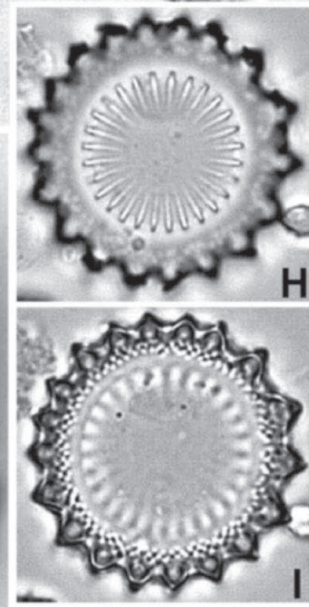

B
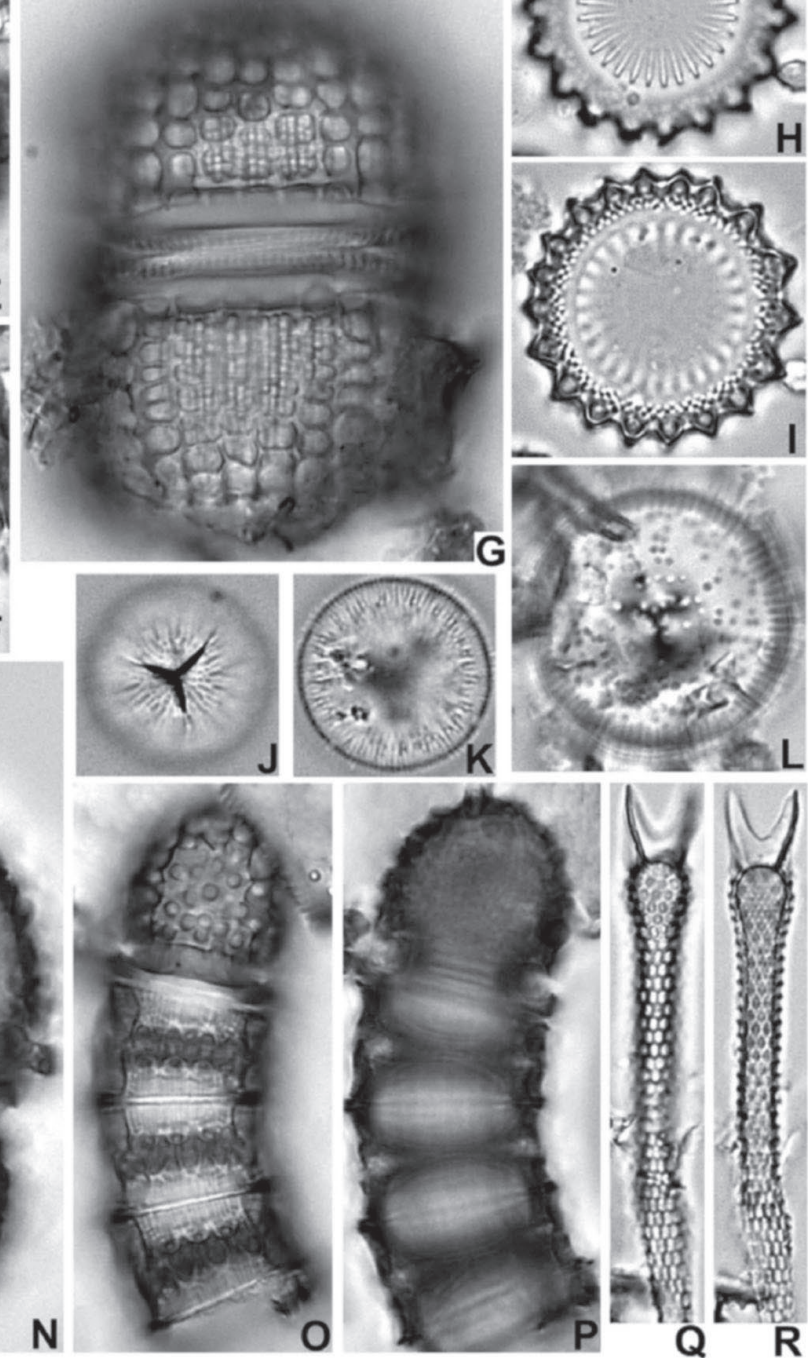

\section{I}

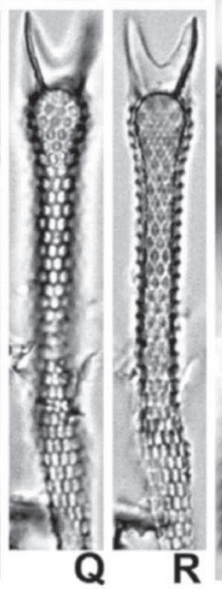

Figure 7. LM photomicrographs of diatoms from Devon Island. Magnification $\times 1500$, unless stated otherwise. A and B. Aulacodiscus sp. cf. A. insignis Hustedt, sample EF0103. Valve view. High and low focus of the same specimen. Magnification $\times 750$. C and D. Hyalodiscus nobilis Pantocsek, sample EF0309. Valve view. High and low focus of the same specimen. E and F, M and N. Costopyxis schulzii (Steinecke ex Schulz) Gleser. $\mathrm{E}$ and F - sample EF0401, frustule in girdle view. High and low focus of the same specimen. M and N - sample EF0103, frustule in girdle view. High and low focus of the same specimen. G. Costopyxis antiqua (Jousé) Gleser, sample EF0402. Frustule in girdle view. H and I. Paralia crenulata (Grunow) Gleser, sample EF0102. Valve view. High and low focus of the same specimen. J and K. Trochosiropsis polychaeta (Strelnikova) Tapia, sample EF0304. Valve view. High and low focus of the same specimen. L. Pyrgodiscus triangulatus Hajós and Stradner, sample EF0402. Valve view. $\mathrm{O}$ and P. Filament of Paralia crenulata terminated with a valve of Costopyxis schulzii in girdle view, sample EF0103. High and low focus of the same specimen. Q and R. Gladius antiquus Forti and Schulz, sample EF0402. Girdle view. High and low focus of the same specimen. S. Gladiopsis speciosa (Schulz) Gersonde and Harwood f. porata Strelnikova, sample VF0102. Girdle view. Magnification ×870. 


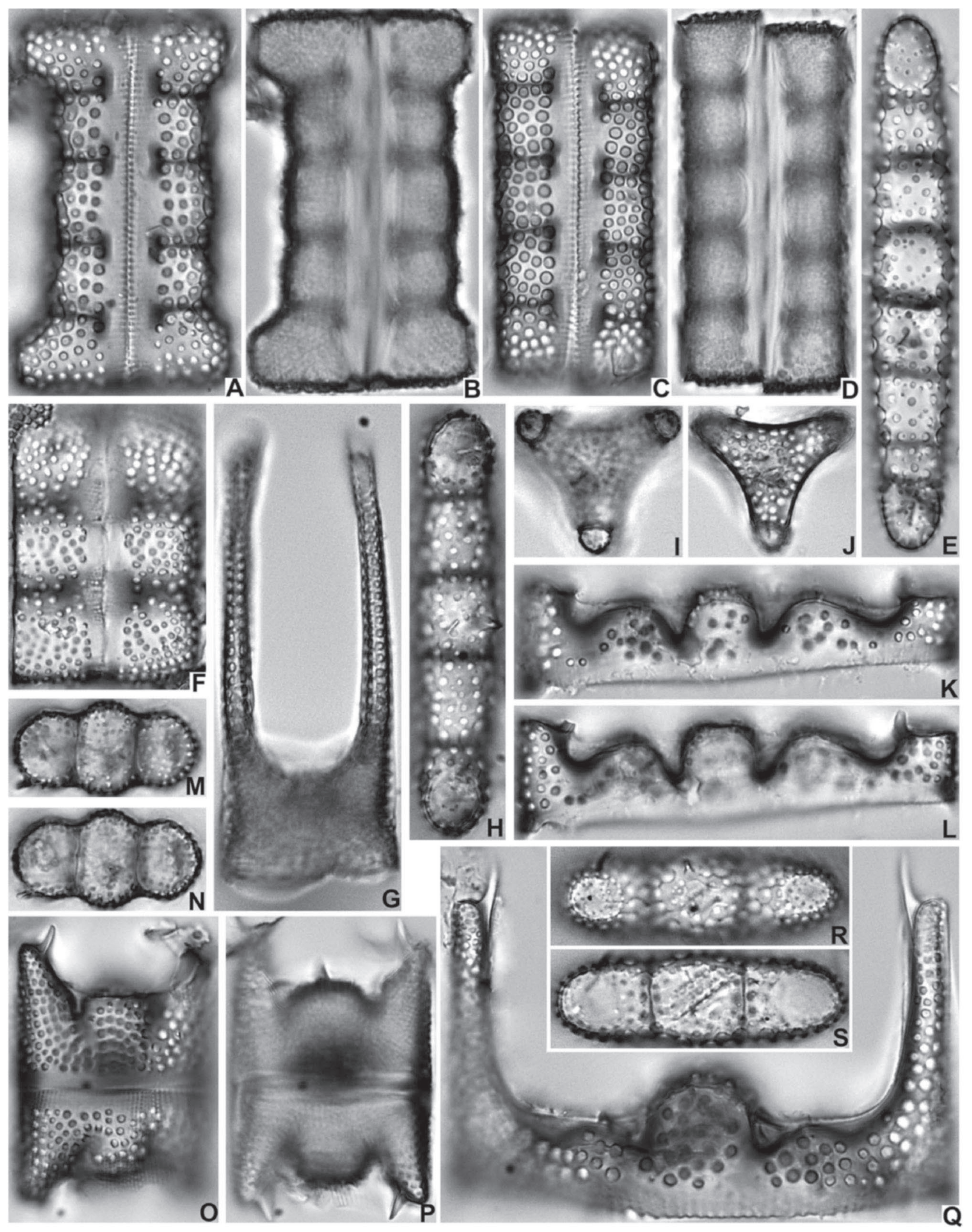

Figure 8. LM photomicrographs of diatoms from Devon Island. Magnification $\times 1500$. A-E, H, R and S. Cortinocornus rossicus (Pantocsek) Gleser. A and B, H, R and S - first morphotype. A and B - sample EF0103. Frustule in girdle view. High and low focus of the same specimen. H - sample EF0103. Valve view. R and S - sample EF0103. Valve view. High and low focus of the same specimen. C-E - second morphotype. C and D - sample EF0304. Frustule in girdle view. High and low focus of the same specimen. E - sample VF0102. Valve view. F, M and N. Cortinocornus? sp. A, sample EF0402. F - frustule in girdle view. M and N - valve view. High and low focus of the same specimen. G. Hemiaulus speciosus Jousé, sample EF0103. Girdle view. I and J. Trinacria indefinita Jousé, sample EF0309. Valve view. High and low focus of the same specimen. K and L. Hemiaulus asymmetricus Jousé, sample EF0103. Girdle view. High and low focus of the same specimen. O and P. Hemiaulus antiquus Jousé, sample EF0304. Frustule in girdle view. High and low focus of the same specimen. Q. Hemiaulus echinulatus Jousé, sample EF0103. Girdle view. 


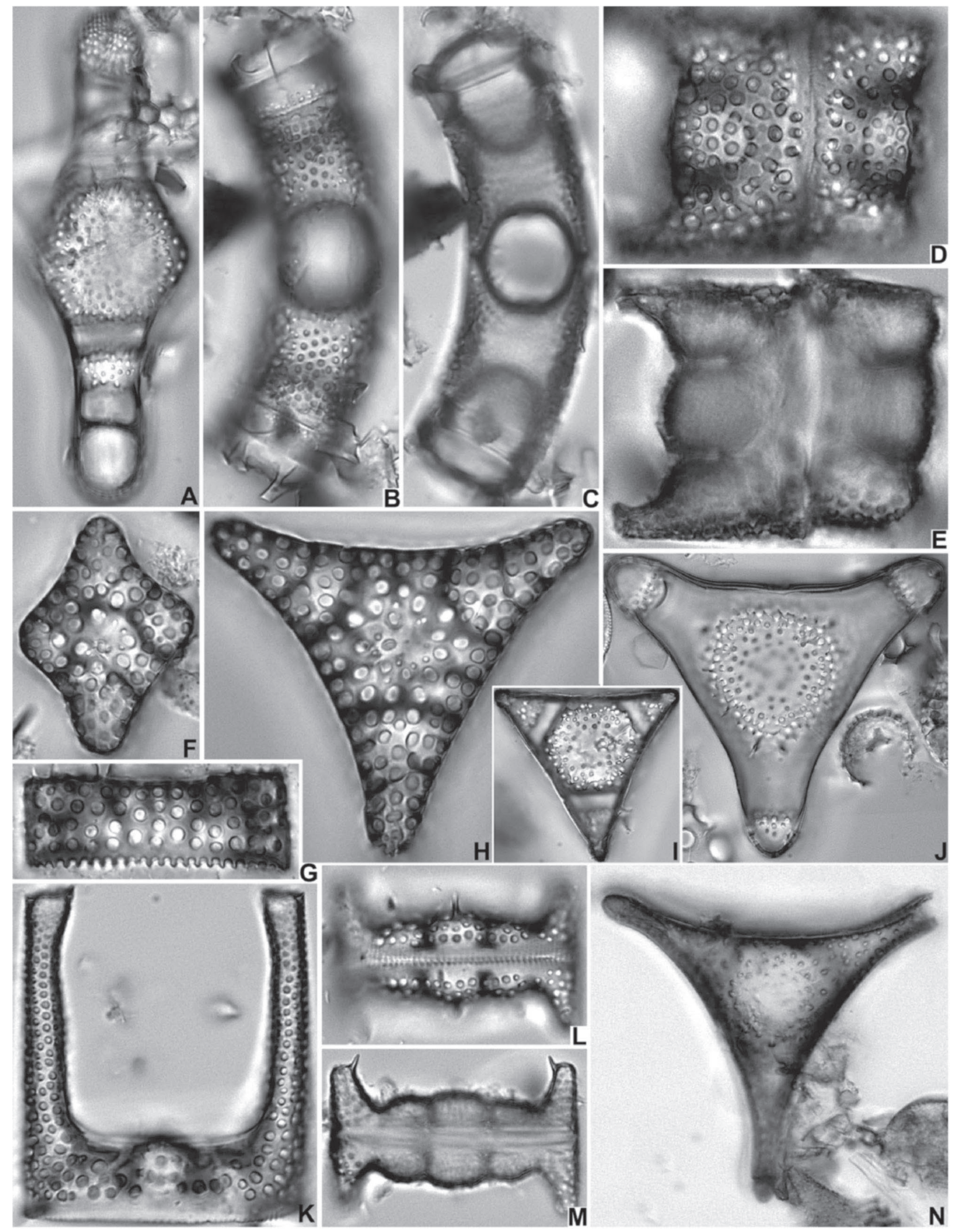

Figure 9. LM photomicrographs of diatoms from Devon Island. Magnification $\times 1500$, unless stated otherwise. A. Briggera includens (Grunow) Ross and Sims, sample EF0107. Valve view. Magnification $\times 1250$. B and C. Hemiaulus sporalis Strelnikova, sample EF0309. Short chain of two vegetative valves, each bearing a semi-endogenous resting spore. Girdle view. High and low focus of the same specimen. D and E. Hemiaulus? sp. A, sample VF0102. Frustule in girdle view. High and low focus of the same specimen. F-H. Medlinia deciusii (Hanna) Nikolaev and Kociolek. F - sample EF0103. Teratoid quadripolar form in valve view. G - sample EF0103. Girdle view. H - sample EF0103. Valve view. I. Medlinia fenestrata (Witt) Sims, sample EF0103. Valve view. Magnification ×900. J. Medlinia weissei (Strelnikova) Sims, sample EF0103. Valve view. Magnification $\times 750$. K. Hemiaulus? sp. B, sample EF0103. Girdle view. L and M. Hemiaulus polymorphus Grunow, sample EF0103. Frustule in girdle view. High and low focus of the same specimen. N. Sheshukovia excavata (Heiberg) Nikolaev and Harwood, sample EF0107. Valve view. Magnification ×750. 

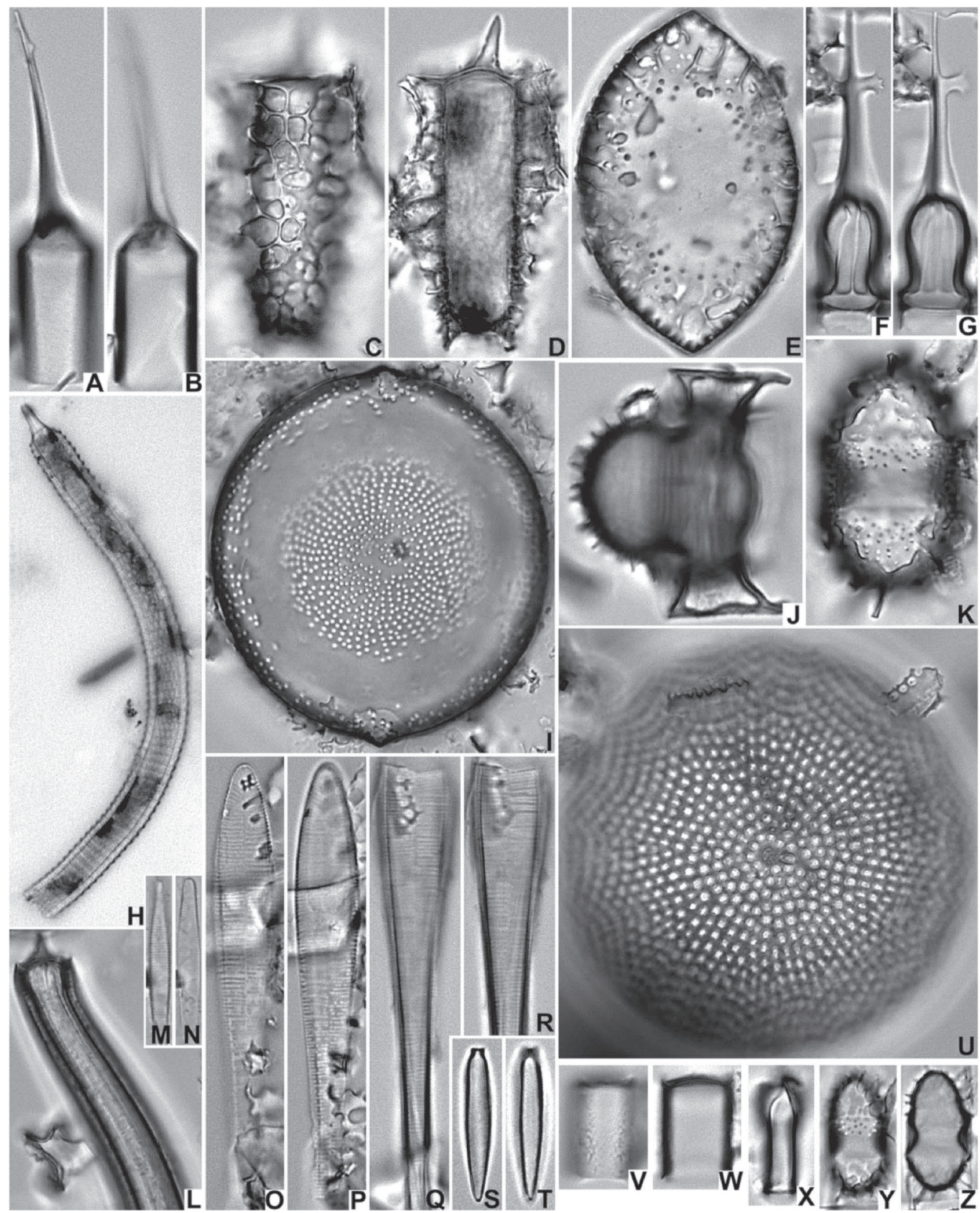

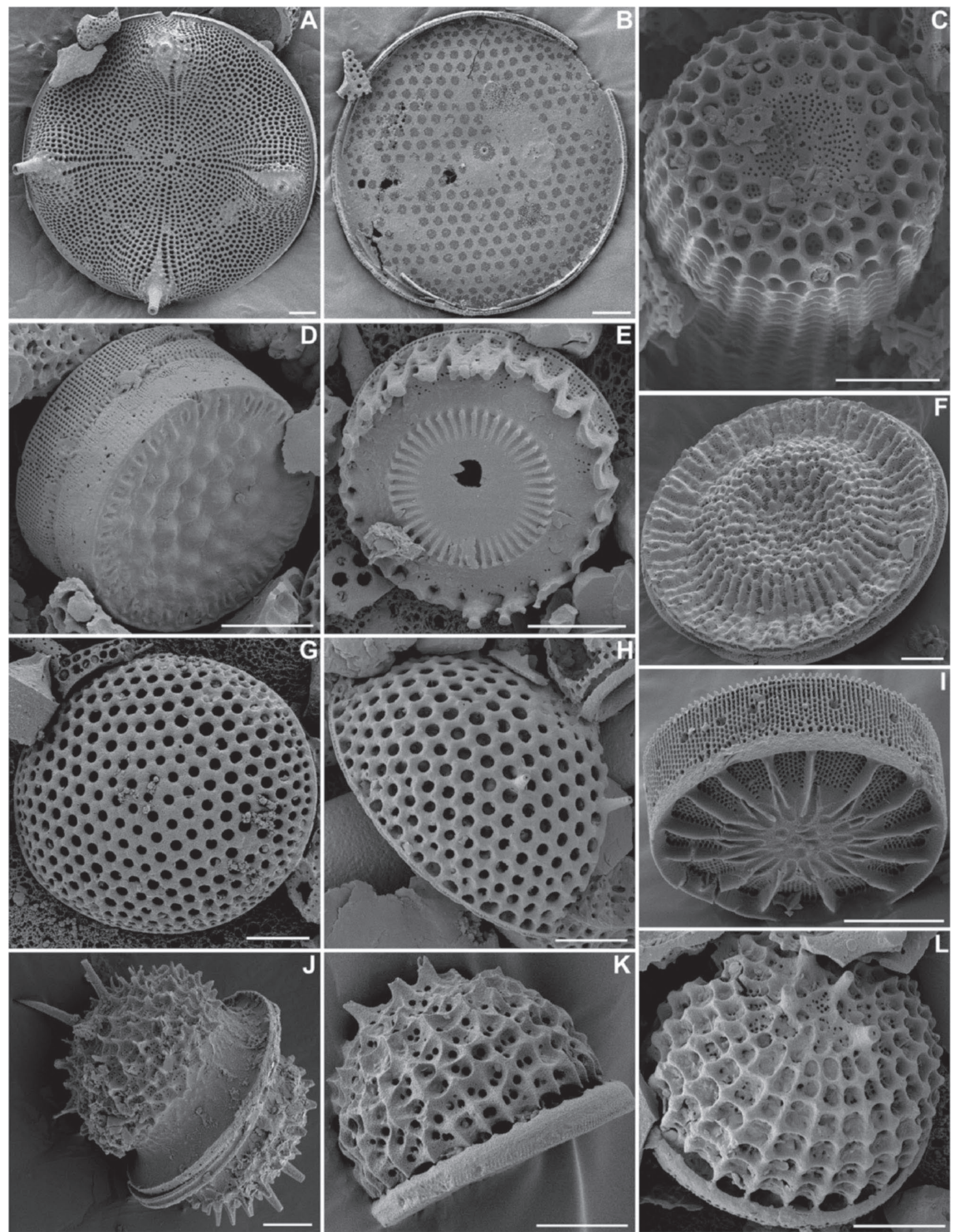

Figure 11. Scanning Electron Microscope (SEM) photomicrographs of diatoms from Devon Island. Scale bars $=10 \mu \mathrm{m}$. A. Aulacodiscus sp. cf. A. insignis Hustedt, sample EF0103. Valve view. B. Thalassiosiropsis wittiana (Pantocsek) Hasle, sample EF0106. Internal valve view. C. Gladiopsis speciosa (Schulz) Gersonde and Harwood f. porata Strelnikova, sample VF0102. Valve view. D. Paralia ornata (Grunow) Grunow ex van Heurck, sample EF0102. Oblique view. E. Paralia crenulata (Grunow) Gleser, sample EF0102. Oblique view. F. Lepidodiscus elegans Witt, sample EF0103. Oblique view. G. Stephanopyxis dissonus (Schulz) Strelnikova and Nikolaev, sample EF0103. Valve view. H. Stephanopyxis grunowii Grove and Sturt, sample EF0102. Oblique view. I. Truania archangelskiana Pantocsek, sample EF0103. Oblique view. J. Costopyxis schulzii (Steinecke ex Schulz) Gleser f. ornata Strelnikova, sample EF0401. Frustule in oblique view. K. Costopyxis schulzii (Steinecke ex Schulz) Gleser, sample EF0106. Girdle view. L. Costopyxis antiqua (Jousé) Gleser, sample EF0102. Oblique view. 
speciosa are present, with low and variable abundance: $\mathrm{f}$. aculeolata, f. porata and f. speciosa (Strelnikova, 1966, 1974). The planktonic nature of this genus is inferred mainly from the cosmopolitan distribution of its representatives (Davies, 2006).

\subsubsection{Resting spore taxa}

An important paleobiological challenge faced by all studies of fossil diatom floras is discriminating between vegetative cells and resting spores. The criteria of Gersonde and Harwood (1990) are followed in the present study, with vegetative cells considered to have relatively lightly silicified frustules with perforate walls and larger cell volume (see also French and Hargraves, 1980; Kitchell et al., 1986). Resting spores are generally considered to lack girdle elements (Hargraves, 1986).

Taxa regarded as probable diatom resting spores represent the second most numerous and diverse group in this study, comprising 27 taxa $(29.7 \%$ of total number of taxa, $33.1 \%$ of the assemblage by abundance) belonging to 14 genera: Chasea, Cladogramma, Costopyxis, Dasyangea, Goniothecium, Hemiaulus, Odontotropis, Poretzkia, Pseudoaulacodiscus, Pseudopyxilla, Pterotheca, Pyrgodiscus, Rhizosolenia and Stellarima. Resting spores are present in all diatom-bearing samples examined in this study, although their relative abundance varies.

Costopyxis is the most abundant taxon in the studied assemblage, occurring in every diatom-bearing sample. The highest abundance is observed in sample VF0305, where C. schulzii constitutes $74 \%$ of the assemblage. Other Costopyxis species encountered in the studied material occur less frequently. Significant morphological variation is observed within this genus (Figure 7E-G, M-P; Figure 11J-L). Costopyxis has previously been regarded as a resting spore (Suto et al., 2009), but it has never been reported in association with chains of Paralia. A chain of Paralia crenulata valves terminated with a valve of C. schulzii (Figure 7O, P) was found in sample EF0103. No similar specimens were found in this study and it cannot be excluded that empty valves of these two genera happened to fit together accidentally. To our knowledge, neither fossil nor extant species of Paralia have previously been reported to form resting spores, and Costopyxis only occurs together with Paralia in the Arctic fossil localities (Strelnikova, 1974; Tapia and Harwood, 2002). We suggest that Costopyxis may have been a resting spore of the genus Paralia, but further study is required.

Pterotheca and Pseudopyxilla are the most diverse resting spore genera in the studied material, represented by seven and four species respectively, although species belonging to these genera rarely exceed a relative abundance of $1 \%$. The most frequently encountered taxa are: Pterotheca evermanni (Figure 10A, B), Pterotheca clavata (Figure 10X) and Pterotheca aculeifera (Figure 10F, G), followed by species of Pseudopyxilla.

Hemiaulus sporalis (Figure 9B, C; Figure 10E; Figure 12K) commonly occurs as semi-endogenous resting spores, often associated with a remnant vegetative valve. In the studied material, the resting spores of this taxon are more abundant than vegetative valves (the maximum abundance of resting spores is $10.4 \%$ in sample EF0307).

Goniothecium odontellum sensu Strelnikova (name applied following Sims and Mahood, 1998) (Figure 12P) is common in the upper part of the section, with a maximum abundance of 5.2\% in sample EF0307, and 4.8\% in samples EF0309 and VF0102. Resting spores of Stellarima steinyi (Figure 10U) are also encountered frequently toward the top of the section (3\% in sample VF0102). Pyrgodiscus triangulatus (Figure 7L) is considered a resting spore, following Harwood (1988).

This study documents the presence of Dasyangea dactylethra (Figure 10K, Y, Z) in deposits younger than the Lower Cretaceous. Spores conforming to the type species description and illustrations (Harwood and Gersonde, 1990) occur in the middle and higher parts of the studied section.

\subsubsection{Tychoplanktonic taxa}

It is difficult to attribute a tychoplanktonic (from Greek "tycho" - "accidental," meaning "accidentally suspended") nature to diatom taxa lacking modern representatives. For this reason, only seven species (within two genera) are included in this group $(7.7 \%$ of the indentified taxa, $9.8 \%$ abundance). Tychoplanktonic preferences are presumed for species of Medlinia (following the suggestion of Davies, 2006) and Paralia (following McQuoid and Nordberg, 2003). Although only seven species are considered to be tychoplanktonic, in certain samples they are the most abundant group (e.g., EF0402, which has $32.7 \%$ tychoplanktonic, and $20.7 \%$ planktonic diatoms). In such samples, species of Paralia can account for more than $20 \%$ of the assemblage. The most common members of this genus are $P$. crenulata (Figure $7 \mathrm{H}, \mathrm{I}$; Figure 11E) in sample VF0104 and Paralia ornata (Figure 6E; Figure 11D) in sample EF0402. Paralia fausta (Figure 6G) and Paralia sulcata (Figure $6 \mathrm{H}$ ) are less frequent and occur only in a few samples.

Medlinia is represented by three species (Figure 9F-J; Figure 12G): Medlinia deciusii (maximum abundance of $1.3 \%$ in sample EF0104), Medlinia fenestrata and Medlinia weissei (occurring with minor abundances). General environmental preferences for Medlinia are unclear. Davies (2006) suggested a neritic environment as the most probable for this genus, based on the considerable silicification of its valves, as well as its limited geographical distribution. In the Kanguk Formation on Devon Island, the relative abundance of valves of $M$. deciusii is constant both in more distal sediments, and in more proximal deposits. For this reason, a tychoplanktonic preference is inferred.

\subsubsection{Benthic and probable benthic taxa}

Benthic diatoms constitute $15.4 \%$ of the studied assemblage in terms of number of taxa, comprising 14 species within the following 9 genera: Actinodictyon, Actinoptychus, Aulacodiscus, Hyalodiscus, Lepidodiscus, Pseudopodosira, Sceptroneis, Sheshukovia and Truania. The abundance of benthic diatoms is the lowest among all ecological groups in the Devon Island deposit $(1.6 \%)$, suggesting that most depositional settings were below the euphotic zone. Environmental assignment of taxa is based mostly on literature conjecture (e.g., Olshtynskaya, 1990; Round et al., 1990; Sims and Crawford, 2007; Tiffany, 2008) and comparisons to extant representatives of the genera. Thus, some of the paleoenvironmental diagnoses remain tentative. Nevertheless, the majority of genera placed in this category are extant; as diatoms of known environmental preference, extant genera do not require a detailed discussion.

Actinodictyon and Lepidodiscus (Figure 6A-D) are large diatoms with numerous processes located close to the margins of the valve, and for this reason are regarded as benthic, probably living attached to various substrates. A benthic affinity is also suggested for Truania (Figure 6F; Figure 11I), an extinct taxon with a restricted geographic distribution (Sims and Crawford, 2007) combined with remarkably heavy silicification of its cells (to date not reported as chains; see Crawford and Sims, 2008).

Sceptroneis is considered an epiphytic taxon (Round et al., 1990). Based on valve outline, two forms are tentatively distinguished in the studied material (Figure 10M-R). This araphid pennate diatom and the related genus Incisoria (Figure 10S, T) of unknown environmental preferences, are observed in only three samples (EF0106, EF0107, EF0304) with good preservation, collected from the upper part of the studied succession. Their individual abundances do not exceed $1 \%$ in any sample.

\subsection{Stratigraphic succession of diatom assemblages}

Three diatom assemblages are identified in the Devon Island samples based on stratigraphic occurrences of the taxa (Figure 14). These assemblages reflect environmental changes and 

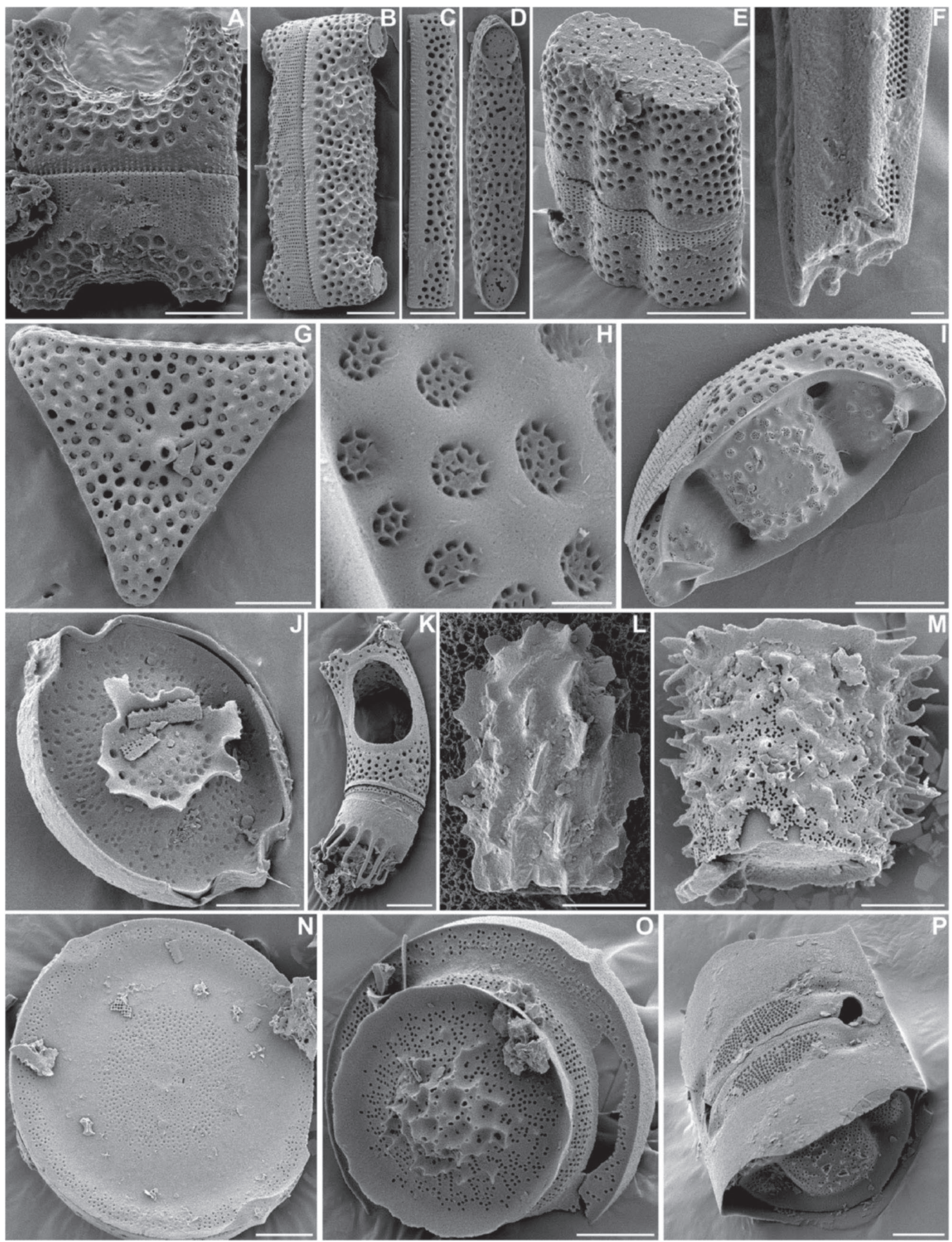

Figure 12. SEM photomicrographs of diatoms from Devon Island. Scale bars $=10 \mu \mathrm{m}$, except for figs. F and H $(1 \mu \mathrm{m})$. A and B. Cortinocornus rossicus (Pantocsek) Gleser, first morphotype, sample EF0103. A. - girdle view. B. - oblique view. Preserved girdle elements visible in both images. C and D. Cortinocornus rossicus (Pantocsek) Gleser, second morphotype, sample EF0106. C. - girdle view. D. - valve view. E. Cortinocornus? sp. A, sample EF0402. Oblique view. F. Proboscia unicornis Jordan and Ito, detail of the proboscis, sample EF0309. G. Medlinia deciusii (Hanna) Nikolaev and Kociolek, sample EF0103. Valve view. H and I. Hemiaulus antiquus Jousé, sample EF0304. H. - detail, showing the exceptional preservation state of cribra occluding the areolae. I. - valve view. J. Poretzkia sp. cf. P. umbonata Gleser, sample EF0106. Oblique view. K. Hemiaulus sporalis Strelnikova, sample EF0309. Paired vegetative cells with a resting spore in girdle view. L. Pterotheca alata Strelnikova, sample EF0103. Girdle view. M. "Pterotheca? sp." Strelnikova, sample EF0102. Girdle view. N and O. Pseudoaulacodiscus sp. A, sample EF0309. N. - epivalve in valve view. O. - hypovalve in valve view. P. Goniothecium odontellum Ehrenberg sensu Strelnikova, sample EF0106. Oblique view. 


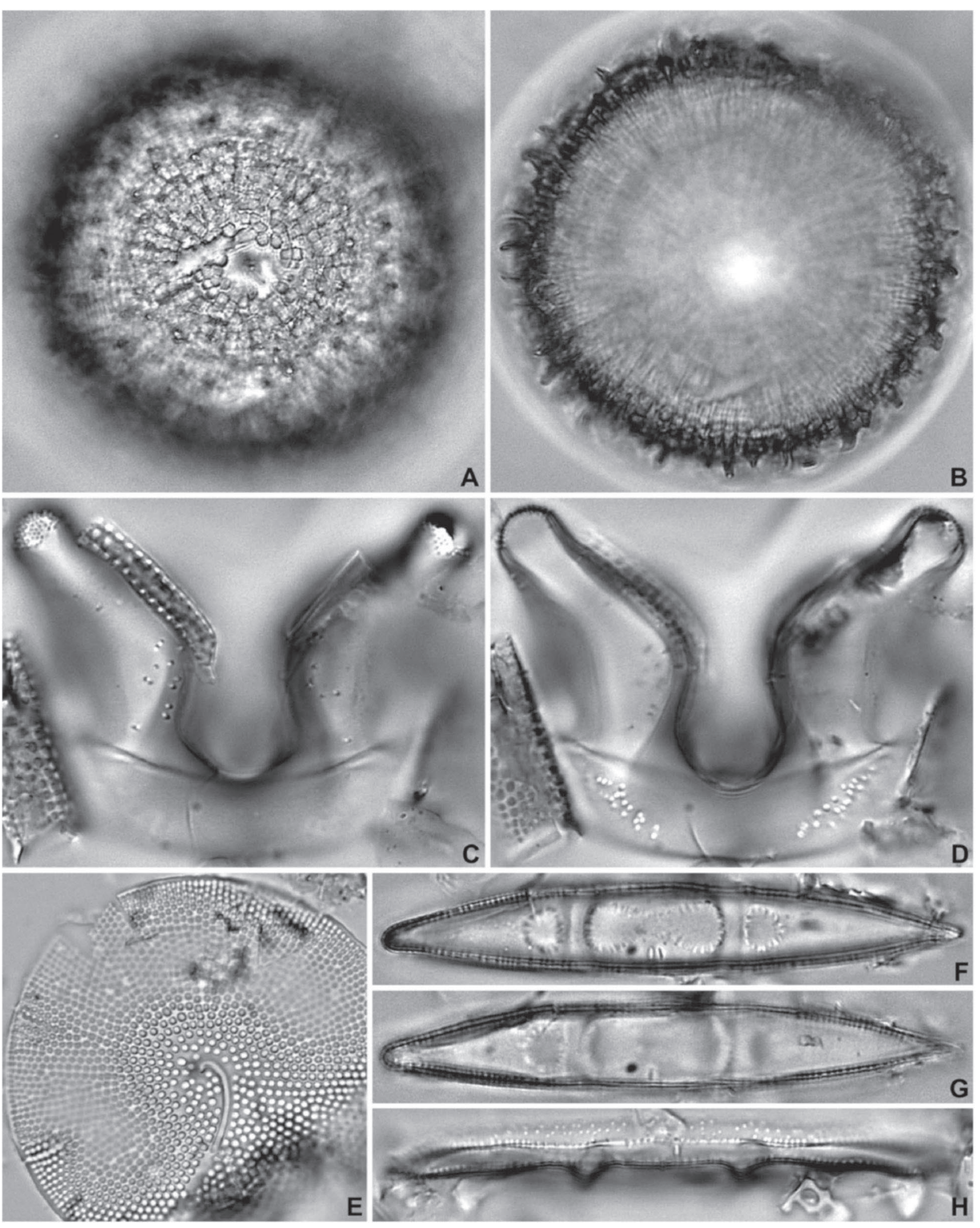

Figure 13. LM photomicrographs of unknown diatom taxa from Devon Island. Magnification $\times 1500$. A and B. Unknown genus and species \#3, sample EF0103. Valve view. High and low focus of the same specimen. C and D. Unknown genus and species \#4, sample EF0103. Girdle view. High and low focus of the same specimen. E. Unknown genus and species \#2, sample EF0402. F-H. Unknown genus and species \#1, sample EF0107. F and G - Valve view, high and low focus of the same specimen. H - Sibling valves, girdle view. 


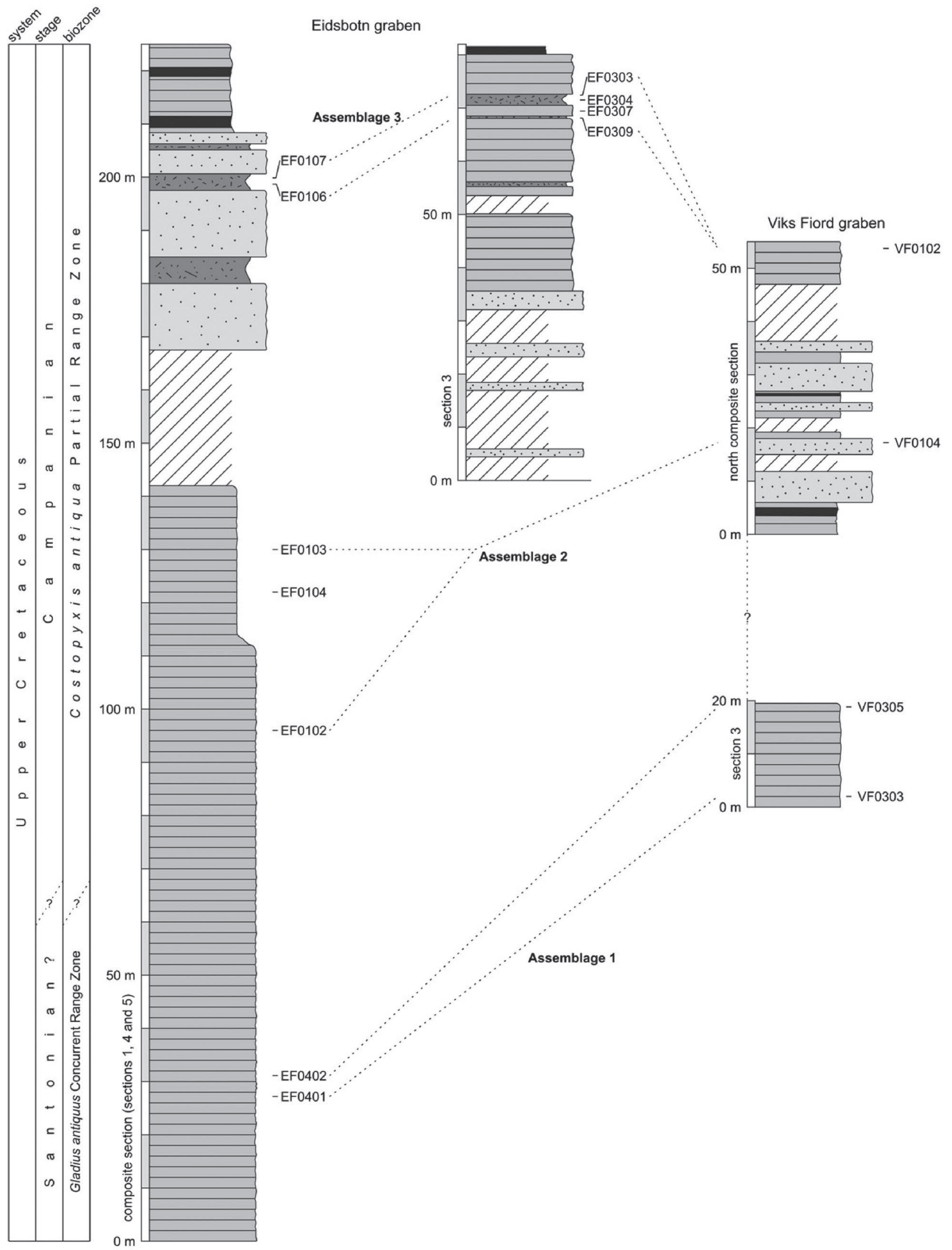

Figure 14. Diatom-based biostratigraphy and correlation of Eidsbotn graben and Viks Fiord graben sections. For lithology explanations see Figure 2. 
depositional conditions, and provide important stratigraphic context for the studied succession.

\subsubsection{Assemblage 1}

Samples EF0401 and EF0402 from the bottom part of the Eidsbotn graben composite section and VF0303 and VF0305 from the Viks Fiord graben section 3 are grouped within assemblage 1 . It includes C. schulzii, P. ornata, P. crenulata, Gladius antiquus (Figure 7Q, R), Archepyrgus sp. aff. A. melosiroides (Figure 6L, M) and Amblypyrgus sp. A (Figure 6N, O).

Samples VF0303 and VF0305 show poor preservation and in many cases allow identification of diatoms only to the generic level. Diatom valves found in both samples are considerably fragmented, and exceptionally high abundances of strongly silicified taxa (C. schulzii accounts for $74 \%$ valves found in sample VF0305) suggest selective dissolution. The number of taxa identified in samples EF0401 and EF0402 is similar, and so are relative abundances of ecological groups (Figure 5). The only significant difference between these Eidsbotn samples concerns the relative abundance of tychoplanktonic taxa; there is a higher proportion of $P$. crenulata and $P$. ornata in sample EF0402. Despite the difference in sediment lithology (sandstone versus mudstone), samples EF0401 and EF0402 occur within $5 \mathrm{~m}$ from each other (which is reflected in their taxonomic similarity) and show moderate to good preservation of siliceous microfossils.

\subsubsection{Assemblage 2}

Assemblage 2 is represented by samples EF0102, EF0104, EF0103 (middle part of the Eidsbotn graben composite section) and VF0104 (lower part of the north composite section in Viks Fiord graben). The most important taxa of this assemblage are: C. rossicus (first morphotype), P. crenulata, $H$. polymorphus var. frigida, C. antiqua, C. schulzii, C. schulzii f. ornata, S. dissonus, S. grunowii and $M$. deciusii. The most abundant species are $C$. schulzii (47.5\% in sample VF0104), and the first morphotype of C. rossicus (37.3\% in sample EF0104).

Samples EF0102, EF0104 and EF0103 were collected from mudstones over an interval of ca. $35 \mathrm{~m}$. The relative abundances of each ecological group within these samples are similar (Figure 5), but the number of taxa identified in EF0103 is higher than in the remaining samples. Sample VF0104 was collected from a mudstone bed in a section of uncertain stratigraphic context, with terrestrial facies interfingering with marine facies, and with three major intervals of indeterminate lithology due to surface layer slumping. Preservation of siliceous microfossils in sample VF0104 is poor. High abundance of C. schulzii (47.5\%) relative to other species in this sample is interpreted as a result of selective dissolution.

\subsubsection{Assemblage 3}

Samples EF0106 and EF0107 (Eidsbotn graben composite section), EF0309, EF0307, EF0304 and EF0303 (Eidsbotn graben section 3), and VF0102 (Viks Fiord graben north composite section) are included in assemblage 3. The most important species in this assemblage are: H. antiquus, C. rossicus (second morphotype), H. asymmetricus, Pseudoaulacodiscus sp. A (Figure 10I; Figure 12N, O), S. steinyi, Trinacria indefinita (Figure $8 \mathrm{I}, \mathrm{J})$, and $D$. dactylethra. Another important taxon present in all of these samples is the unknown genus and species \#1 (Figure 13F-H), accounting for more than $21 \%$ of the valves counted in sample EF0304. Except for mudstone samples EF0307 and VF0102, all samples in this group were collected from bentonite beds. The number of species ranges from 34 (EF0307) to 55 (EF0106). Percentages of each ecological group are similar in all samples within this assemblage (Figure 5). Samples collected near the top of Eidsbotn section 3 are relatively closely spaced and cover a short stratigraphic inter- val (about $10 \mathrm{~m}$ ). Preservation of diatom valves in most of the samples in this assemblage (except for EF0303) is exceptionally good (e.g., Figure 4A; Figure 12H).

\section{Discussion}

\subsection{Biostratigraphy}

Diatoms recovered from Kanguk Formation outcrops on Devon Island occur in sufficient numbers to reconstruct their stratigraphical context relative to other diatom-bearing deposits in the Arctic Ocean region. The irregular sample spacing, however, does not allow establishment of an independent biostratigraphic zonation; most diatom-based biostratigraphic frameworks for Cretaceous sediments have been erected based on continuous successions from both continental outcrops (West Siberian Lowlands: Strelnikova, 1974; Canadian Margin: Tapia and Harwood, 2002) and oceanic drilling (DSDP Site 275: Hajós and Stradner, 1975).

Sediments outcropping in the studied grabens are not precisely dated because of the preservational bias against calcareous fossils and because correlation between the sequences exposed in both grabens is unclear. The only stratigraphic markers beside the diatoms reported herein, are the palynomorphs T. plicatilis, found in the upper part of the Kanguk Formation exposure at Eidsbotn graben and W. edmontoniacola, present in the Expedition Fiord Formation at Viks Fiord graben (Chin et al., 2008). These suggest an equivalence with the Campanian of Alberta and indicate the following time intervals: 73-76 Ma (T. plicatilis) and 72-73.5 Ma (W. edmontoniacola) (Lerbekmo and Braman, 2002; Chin et al., 2008).

The biostratigraphic zonation proposed for the Canadian Arctic by Tapia and Harwood (2002) is based on stratigraphic sections and samples collected by Geological Survey of Canada geologists during surveys of Ellesmere Island, Ellef Ringnes Island, Eglington Island and the Anderson Plains in Northwest Territories, mainland Canada. Four biostratigraphic units for the Cenomanian through the Campanian of the Canadian Arctic area were described (Tapia and Harwood, 2002): (1) the G. antiquus Concurrent Range Zone, defined as the interval between the first occurrence of Basilicostephanus sp. 1 and the last occurrence of G. antiquus; (2) the C. antiqua Partial Range Zone, comprising the interval from the last occurrence of G. antiquus up to the last occurrence of the nominative taxon; (3) the Trinacria indefinita Interval Zone, comprising the interval between the last occurrence of $C$. antiqua and the first occurrence of Stephanopyxis simonseni; and (4) the S. simonseni Partial Range Zone, spanning the stratigraphic interval up to the first occurrence of Azpeitiopsis morenoensis. Application of the Tapia and Harwood (2002) diatom zonation scheme to the sequences on Devon Island suggests that the studied interval of the Kanguk Formation should be placed within the two lowermost zones, tentatively dated for the Santonian (assemblage 1) and the Campanian (assemblages 2 and 3).

Assemblage 1 is correlative with the G. antiquus Concurrent Range Zone, based on the presence of the following taxa: G. antiquus, C. schulzii, C. schulzii f. ornata, G. speciosa, P. ornata (Tapia and Harwood, 2002). Additional taxa known to co-occur with G. antiquus in the Lower Cretaceous are also found in the deposit: Amblypyrgus sp. A and Archepyrgus sp. aff. A. melosiroides (both restricted to assemblage 1), plus D. dactylethra (found in assemblages 2 and 3). Tapia and Harwood (2002) reported the last occurrence of G. antiquus (zonal marker for the top of this biostratigraphic unit) to approximate the SantonianCampanian boundary. G. antiquus is present in all samples included in assemblage 1, but absent from assemblages 2 and 3, suggesting that the Santonian-Campanian boundary occurs in the sediments between samples EF0402 and EF0102. Tapia 


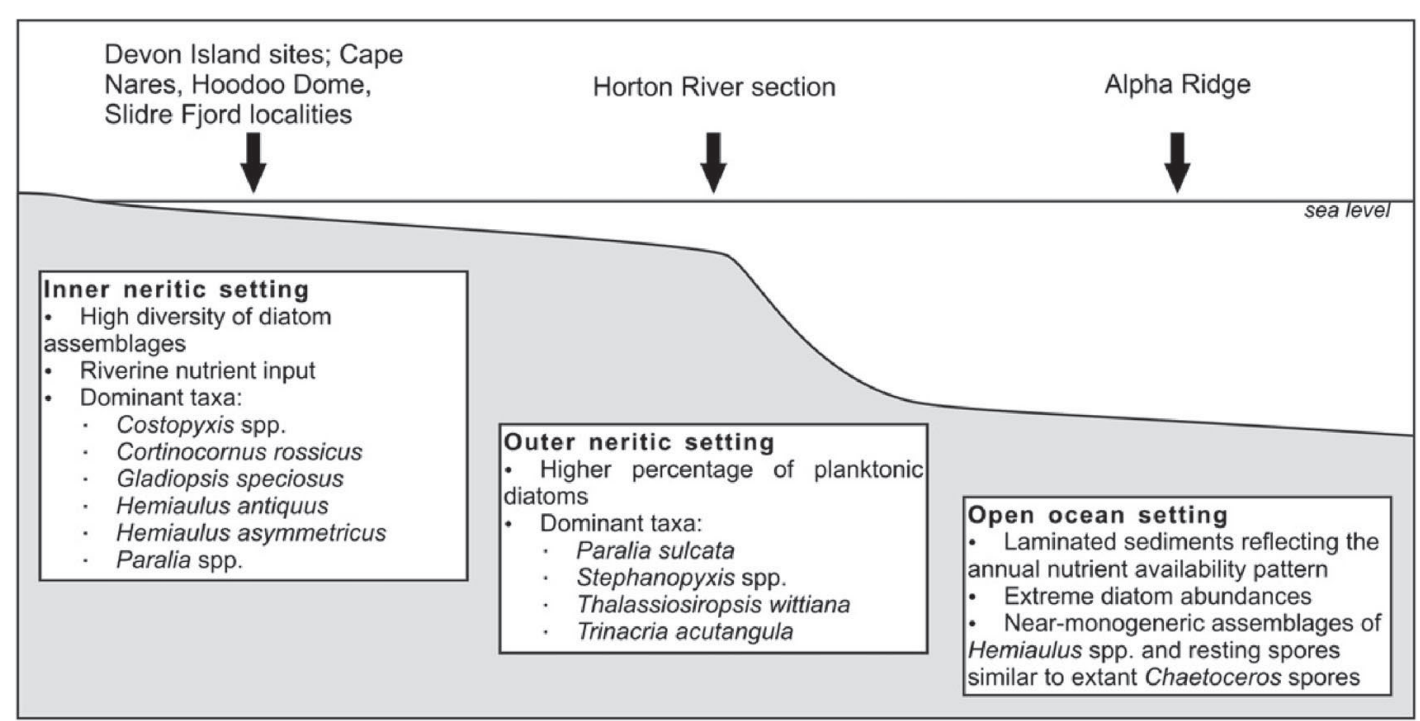

Figure 15. Diagram showing an idealized cross-section along a water-depth transect on the Late Cretaceous shelf of the Arctic Ocean. The inferred position and relative paleodepth of the sites discussed in this paper are indicated. For details concerning localities other than Devon Island field sites please refer to Tapia and Harwood (2002) and Davies et al. (2009).

and Harwood (2002) did not report occurrences of the genera Amblypyrgus and Archepyrgus from the Santonian of the Canadian Arctic, but Gersonde and Harwood (1990) described both genera from the Aptian-Albian deposits of the Weddell Sea, Antarctica. The diatom assemblages recovered from samples EF0401 and EF0402 differ significantly from all other samples collected in the Eidsbotn graben, however, they do not provide any constraints for the age of the bottom part of the studied succession, which may extend down below the Santonian. Thus, from data in this study, it is only possible to conclude that the sediments comprised in assemblage 1 were deposited between the Albian and the end of the Santonian. The presence of G. antiquus in section 3 of Viks Fiord graben provides a means of correlation between sections within this graben, indicating that section 3 underlies the north composite section.

An additional biostratigraphic marker found in samples EF0401 and EF0402, Thalassiosiropsidella simsii, allows correlation with the Cretaceous diatom-bearing sequence of ODP Hole 748C (Nikolaev and Harwood, 2007). To date, this rare taxon has only been reported from one core-section in the upper Campanian of the central Kerguelen Plateau (Shipboard Scientific Party, 1989). Its presence in the inferred Santonian interval of the Kanguk Formation on Devon Island clearly indicates its global distribution and a longer stratigraphic range.

Both assemblages 2 and 3 are correlative with the $C$. antiqua Partial Range Zone of Tapia and Harwood (2002), based on the presence of C. antiqua, Basilicostephanus sp. 1, C. schulzii, C. schulzii f. ornata, L. elegans, P. ornata and M. deciusii. In the Devon Island sections, this zone comprises two quite distinct diatom assemblages. Although T. indefinita, the nominative taxon for the overlying Interval Zone is a part of assemblage 3, the zonal marker for the top of $C$. antiqua Zone is not observed in this study. This suggests that in the future studies, C. antiqua Zone may be subdivided into two or more biostratigraphic units. According to Tapia and Harwood (2002), the C. antiqua Zone correlates roughly with the diatom complex "I" of Strelnikova (1974).

\subsection{Paleogeographic setting and paleoecology}

In the Late Cretaceous, the Arctic Ocean apparently shared only shallow water connections with water bodies to the south (Magavern et al., 1996; Baraboshkin et al., 2003), and the coast was located south of the localities discussed in this pa- per (Núñez-Betelu et al., 1995a; Falcon-Lang et al., 2004). As suggested by the taxonomic composition of fossil diatom flora (Tapia and Harwood, 2002), the Horton River section in the Northwest Territories is inferred to have been located further out on the shelf at the time of deposition, closer to a connection with the Western Interior Seaway (Magavern et al., 1996; Jenkyns et al., 2004; Davies et al., 2009). Other localities investigated by Tapia and Harwood (2002) were located at inner shelf settings, similar to the sections on Devon Island. The present-day Alpha Ridge sediments (Davies et al., 2009) were deposited in a deeper part of the Arctic Ocean basin, farther north (Figures 1 \& 15).

Of the 91 fossil marine diatom taxa encountered in the Kanguk Formation outcrops on Devon Island, 47 are also found in Eurasian high latitude assemblages described by Strelnikova (1974), and 37 are present in Canadian High Arctic assemblages examined by Tapia and Harwood (2002). In addition, taxa reported herein have also been previously identified from oceanic settings, including 28 taxa from the Alpha Ridge in the Arctic Ocean: 16 taxa from the CESAR 6 core (Barron, 1985; Davies, 2006), and 12 taxa from core Fl-437 (Dell'Agnese and Clark, 1994). In terms of paleobiogeographic affiliation, the studied community should be placed in the Boreal province, along with similar assemblages from the Ural Mountains, the Arctic Ocean basin, and the Canadian sector of the Arctic (Strelnikova, 1975).

In the Eidsbotn graben composite section, greensands overlay, or are intercalated with dark, biogenic diatomaceous mudstones. Detrital silt content is minor, but intense bioturbation is reported (Chin et al., 2008). Such sediments can be deposited in upwelling zones, where diatoms occur in great numbers (Dell'Agnese and Clark, 1994; Abrantes, 2000). During upwelling, diatoms bloom in reaction to rapid nutrient uptake, followed by resting stage formation after the nutrients are exhausted (Tappan, 1980; Dell'Agnese and Clark, 1994). This pattern is particularly distinct in the fossil record in such localities as the Alpha Ridge in the Arctic Ocean (Barron, 1985; Davies, 2006; Davies et al., 2009). Although high productivity is evident at the Devon Island localities studied herein, the Late Cretaceous paleogeography of the area appears to have precluded the existence of deep water upwelling in the southeastern portion of the Sverdrup Basin. Riverine input is indicated as a more likely source of nutrients (Chin et al., 2008).

The thickness of biosiliceous mudstones in the lower part of the section at the Eidsbotn graben exceeds $140 \mathrm{~m}$. In sam- 
ples EF0102 and EF0103, planktonic diatoms dominate the assemblage, with a lower abundance of tychoplanktonic forms (mostly P. crenulata and P. ornata). Representatives of the genus Aulacodiscus are indicative of shallow marine conditions (Round et al., 1990), and are present in low concentrations in these samples. This suggests transport and deposition within a short distance from the coast.

The characteristics of the Devon Island sediments support the interpretation of the lower mudstones as more distal sediments, with the greensands as more proximal beds. Sedimentary structures (ripple marks and hummocky cross-stratifications) preserved in all sections confirm deposition on the continental shelf, but it is impossible to estimate paleodepth for particular assemblages.

Rigby et al. (2007) described sponges preserved in the greensands of Eidsbotn graben and suggested a habitat for these organisms within the photic zone, based on their occurrence high in the regressive section, the bioturbation of the sediment, the presence of wood debris and other terrigenous plant material, and thin intercalations of conglomerate. No diatom remains were found in the greensand samples; however, diatom valves are abundant in coprolites occurring in this glaucony facies. Thin sections of coprolites from benthic feeders reveal that glauconite often formed within radiolarian tests (Chin et al., 2008). Furthermore, aggregates of diatom valves and clastic material overgrown by glauconite are frequent in sample EF0307. The absence of diatoms in the greensands may therefore be caused by secondary changes associated with glauconite formation.

Conversely, diatoms encountered in bentonite samples EF0106, EF0107, EF0304 and EF0309 show excellent preservation (Figure 4A; Figure 12H). Percentages of planktonic diatoms are exceptionally high in these samples. This appears to be inconsistent with the sedimentological context that indicates an obvious regressive sequence; high percentages of planktonic diatoms are normally indicative of more oceanic conditions. Bentonite beds represent episodes of rapid deposition of pyroclastic material (Desmares et al., 2007). Catastrophic events like the $1991 \mathrm{Mt}$. Pinatubo eruption are known to cause severe mortality in marine populations (Kuhnt et al., 2005), accompanied by rapid formation of thick layers of silicate-rich sediment. Such input of siliceous pyroclastic material into marine waters normally undersaturated with respect to silica content, is regarded as a major factor contributing to the exceptionally good preservation of diatom valves in the discussed samples. In contrast, it is estimated that under normal oceanic conditions, more than $50 \%$ of biogenic opal produced in the photic zone can be dissolved in the upper $100 \mathrm{~m}$ of the water column (Zielinski and Gersonde, 1997). According to Tappan (1980 and references therein) as little as $0.6-6 \%$ of the actual planktonic diatom population is preserved in a taphocenosis. For these reasons, the taxonomic composition of diatom assemblages recovered from the bentonite samples in this study is considered more representative of original diatom populations at the time of deposition than assemblages from mudstone samples, which should be regarded as timeaveraged. It is also interesting that benthic diatoms are only found in significant abundance in samples EF0106 and EF0107 in Eidsbotn graben, and sample VF0102 in Viks Fiord, but not in the correlative part of Eidsbotn section 3. This discrepancy might have been caused by paleogeographic or paleobathymetric differences.

Observations made during the course of this study allow for comparisons among important Upper Cretaceous diatombearing deposits in the Canadian Arctic, through a paleoenvironmental transect (Figure 15). Although the shallow neritic localities studied by Tapia and Harwood (2002), i.e., Cape Nares, Hoodoo Dome and Slidre Fjord, offer a more continu- ous succession and a higher number of diatom-bearing samples, the material from the Kanguk Formation has generally better preservation on Devon Island. In addition, more information on the paleoecology of the deposit is available (Chin et al., 2008). These assemblages indicate that highly diverse diatom floras composed mostly of planktonic and resting spore taxa appear to be common features of the shallow neritic fossil localities in the Arctic; prevalent genera in these communities include Costopyxis, Cortinocornus, Gladiopsis, Hemiaulus and Paralia. Riverine input is regarded the main source of nutrients supporting the rich diatom communities at the Devon Island sites (Chin et al., 2008). No laminated sediment sequences are reported from any of the near-shore localities, hence no inferences with regard to seasonal deposition can be made. The diversity and abundance of Hemiaulus in all of the shallow neritic deposits demonstrate that this genus was a particularly important primary producer in Late Cretaceous Arctic communities (for a detailed discussion, see Davies et al., 2009).

The assemblage from the Horton River section (Tapia and Harwood, 2002) is inferred to have been deposited in deeper neritic conditions, as indicated by the prevalence of planktonic diatoms, most notably T. wittiana and species of Stephanopyxis and Trinacria. All of these taxa constitute only a minor fraction of the shallow neritic assemblages. Although no distinct laminations are reported for this section, the data of Tapia and Harwood (2002) show resting spore taxa, like Costopyxis spp., to occur in high numbers in some samples. This might be regarded as evidence for a seasonal succession in deposition of resting spores and vegetative valves.

There are significant differences in preservation and diversity between fossil diatoms from the Alpha Ridge and the sites investigated in this study. Davies et al. (2009) reported pristine valves deposited in "grazer-proof" aggregates with negligible fragmentation, whereas some of the diatom communities reported herein suffered from both fragmentation and dissolution. The assemblages reported from the Alpha Ridge are also less diverse (Barron, 1985), reflecting the higher latitude and oceanic setting in which they lived. Quantitative studies, however, revealed that diatom abundances at the Alpha Ridge were comparable to the most productive areas of the modern oceans (Davies et al., 2009). The near-monogeneric laminae dominated by species of Hemiaulus (vegetative cells) and resting spores resembling modern taxa of Chaetoceros, were interpreted to reflect the annual cycle of nutrient availability (Davies et al., 2009). The taxonomic composition of diatom resting spores differs significantly between the neritic and oceanic settings, with Costopyxis flourishing in inner and outer shelf areas, and spores related to the extant Chaetoceros taxa prevailing in the open ocean. It is possible, however, that these apparent differences in diatom communities reflect differences in preservation and/or geological age.

\section{Conclusions}

Upper Cretaceous sediments and fossils on Devon Island offer a truly unique taphonomic window on an ancient polar ecosystem (Chin et al., 2008). Documentation and analyses of the Devon Island diatom flora presented here reveal great diversity and establish a biostratigraphic framework to support a Santonian-Campanian age and placement within the G. antiquus Concurrent Range Zone and the overlying C. antiqua Partial Range Zone (Figure 14). Preservation of diatoms is excellent in some samples, chiefly those associated with a bentonite matrix; in these deposits structural details of diatom valves are exceptionally well-preserved, including the coverings of cribral pores (Figure 12H). The bentonite beds represent rapid sedimentation episodes, and at the same time offered a buffering effect against dissolution that fostered preservation of bio- 
siliceous remains. Thus, the assemblages recovered from bentonites can be considered a close approximation of the actual biocenosis with respect to taxonomic composition.

Diatom assemblages from the Kanguk Formation exposed in Eidsbotn and Viks Fiord grabens are compared to previously published reports, allowing the evaluation of diatom communities along a depth transect from inner neritic settings at Devon Island (this report), Slidre Fjord (Ellesmere Island), Hoodoo Dome (Ellef Ringnes Island) and Cape Nares (Eglington Island) localities (Tapia and Harwood, 2002), through an outer neritic setting at Horton River (Northwest Territories; Tapia and Harwood, 2002), to a deep water oceanic site on the Alpha Ridge in the Central Arctic Ocean (Barron, 1985; Davies et al., 2009) (Figure 15). Analysis of the compositions of these assemblages demonstrates that inner neritic diatom assemblages, dwelling in coastal waters rich in nutrients from riverine discharge, are characterized by high percentages and diversity of planktonic forms and resting spores. High abundances of planktonic diatoms in well-preserved samples from the Horton River section confirm its outer neritic setting inferred from sedimentological premises (Tapia and Harwood, 2002). The open Arctic Ocean setting, as recorded in the Alpha Ridge sediments (Davies et al., 2009), is represented by a sequence of near-monogeneric interbedded laminae of vegetative cells and resting spores different from the community flourishing in the shallow neritic setting.

The fossil record of the Cretaceous Devon Island localities reveals an Arctic marine ecosystem that was shaped and supported by highly diverse and abundant populations of marine diatoms. Many of the diatom species from the Devon Island sites occurred at other places and/or times in the Late Cretaceous Arctic, but this study shows that analyses of the taxa and their sedimentological and paleontological context allow for comparisons of diatom assemblages from inner neritic, outer shelf, and open marine settings. The study also points to different patterns of diatom preservation. These observations shed light on the structure and composition of marine diatom communities in an ancient and more temperate Arctic with no modern counterpart.

\section{Acknowledgments}

We are indebted to John Bloch for helpful discussions and providing material for the study. We also thank Jaelyn Eberle and Steve Cumbaa for their work in recovering the samples and Doug Stenton, Julie Ross, and the Government of Nunavut for allowing us to study the material. Patricia Sims and Nina Strelnikova are thanked for valuable discussions on the taxonomic composition of the studied community. Manfred Ruppel is thanked for SEM examination and photography of the specimens. We also thank Diane Winter, Andrzej Witkowski, Brygida Wawrzyniak-Wydrowska, and Ireneusz Walaszczyk for supporting our work, and two anonymous reviewers for their comments, which greatly improved the manuscript. This paper is a summary of an MSc project accomplished in the Faculty of Geology, University of Warsaw, Poland, advised by Krzysztof Bińka. A portion of this research was funded by NSF Polar Programs Award 0241002. The final draft of this report was completed at the Urbino Summer School in Paleoclimatology in 2009.

\section{References}

Abrantes, 2000 - F. Abrantes, 200000 yr diatom records from Altantic upwelling sites reveal maximum productivity during LGM and a shift in phytoplankton community structure at $185000 \mathrm{yr}$, Earth and Planetary Science Letters 176 (2000), pp. 7-16.

Armbrust, 2009 - E. V. Armbrust, The life of diatoms in the world's oceans, Nature 459 (2009), pp. 185-192.

Baraboshkin et al., 2003 - E. Yu. Baraboshkin, A. S. Alekseev, and L. F. Kopaevich, Cretaceous palaeogeography of the North-Eastern Peri-Tethys, Palaeogeography, Palaeoclimatology, Palaeoecology 196
(2003), pp. 177-208.

Barron, 1985 - J. A. Barron, Diatom biostratigraphy of the CESAR 6 core, Alpha Ridge. In: H. R. Jackson, P. J. Mudie and S. M. Blasco, eds., Initial Geological Report on CESAR. The Canadian Expedition to Study Alpha Ridge, Arctic Ocean, Geological Survey of Canada Paper 84-22 (1985), pp. 137-148.

Bitschene et al., 1992 • P. R. Bitschene, M. A. Holmes, and J. M. Breza, Composition and origin of Cr-rich glauconitic sediments from the Southern Kerguelen Plateau (Site 748). In: S. W. Wise Jr. and R. Schlich et al., eds., Proceedings of the Ocean Drilling Program, Scientific Results vol. 120, Ocean Drilling Program, College Station, TX (1992), pp. 113-134.

Bloch et al., 2004 - J. D. Bloch, K. Chin, A. R. Sweet, J. J. Eberle, and S. L. Cumbaa, S. L., Terminal Late Cretaceous regression on the southeast margin of the Sverdrup Basin: shale and bentonite petrology of the upper Kanguk Formation, Devon Island, Nunavut, Geological Society of America, Abstracts with Programs 36 (2004), p. 461.

Bloch et al., 2007 • J. D. Bloch, M. Spilde, L. L. Heizler, and N. Dunbar, Glass to glaucony: greensand genesis in the Late Cretaceous Kanguk Formation, Devon Island Nunavut. In: 44th Annual Meeting of the Clay Mineral Society, Santa Fe, New Mexico, USA, June 2-7, 2007, p. 56.

Borkowska and Smulikowski, 1973 - M. Borkowska and K. Smulikowski, Minerały Skałotwórcze, Wydawnictwa Geologiczne, Warszawa (1973) (in Polish).

Chafetz, 2007 - H. S. Chafetz, Paragenesis of the Morgan Creek Limestone, Late Cambrian, Central Texas: constraints on the formation of glauconite, Deep Sea Research Part II 54 (2007), pp. 1350-1363.

Chin et al., 2008 • K. Chin, J. D. Bloch, A. R. Sweet, J. S. Tweet, J. J. Eberle, S. L. Cumbaa, J. Witkowski, and D. M. Harwood, Life in a temperate Polar sea: a unique taphonomic window on the structure of a Late Cretaceous Arctic marine ecosystem, Proceedings of the Royal Society B 275 (2008), pp. 2675-2685.

Cleve,1873 - P. T. Cleve, On diatoms from the Arctic Sea, Bihang till Kongliga Svenska Vetenskaps-Akademiens Handlingar 1 (1873), pp. $1-28$.

Crawford and Sims, 2008 - R. M. Crawford and P. A. Sims, Some principles of chain formation as evidenced by the early diatom fossil record, Monographic Series: Nova Hedwigia Beiheft 33 (2008), pp. 171-186.

Davies, 2006 - A. Davies, High resolution palaeoceanography and palaeoclimatology from mid and high latitude Late Cretaceous laminated sediments. Unpublished PhD thesis, University of Southampton, School of Ocean and Earth Science, 2006.

Davies et al., 2009 • A. Davies, A. E. S. Kemp, and J. Pike, Late Cretaceous seasonal ocean variability from the Arctic, Nature 460 (2009), pp. 254-258.

Dell'Agnese and Clark, 1994 • D. J. Dell'Agnese and D. L. Clark, Siliceous microfossils from the warm late Cretaceous and early Cenozoic Arctic Ocean, Journal of Paleontology 68 (1994), pp. 31-47.

Desmares et al., 2007 • D. Desmares, D. Grosheny, B. Beaudoin, S Gardin, and F. Gauthier-Lafaye, High-resolution stratrigraphic record constrained by volcanic ash beds at the CenomanianTuronian boundary in the Western Interior Basin, USA, Cretaceous Research 28 (2007), pp. 561-582.

Dyke, 1999 - A. S. Dyke, Last Glacial Maximum and deglaciation of Devon Island, Arctic Canada: support for an Innuitian ice sheet, Quaternary Science Reviews 18 (1999), pp. 393-420.

Embry, 1991 - A. F. Embry, Mesozoic history of the Arctic Islands. In: H. P. Trettin, ed., Geology of the Innuitian Orogen and Arctic Platform of Canada and Greenland, Geological Survey of Canada, Geology of Canada vol. 3 (1991), pp. 371-433.

Falcon-Lang et al., 2004 • H. J. Falcon-Lang, R. A. MacRae, and A. Z. Csank, Palaeoecology of Late Cretaceous polar vegetation preserved in the Hansen Point Volcanics, NW Ellesmere Island, Canada, Palaeogeography, Palaeoclimatology, Palaeoecology 212 (2004), pp. 45-64.

Forti, 1909 - A. Forti, Studi per una monografia del genere Pyxilla (Diatomeae) e dei generi affini, Nuova Notarisia 20 (1909), 19-34 (in Italian).

Forti and Schulz, 1932 - A. Forti and P. Schulz, Erste Mitteilung über Diatomeen aus dem hannoverschen Gault, Beihefte zum Botanischen Centralblatt 50 (1932), 241-246 (in German).

Fortier et al., 1963 • Y. O. Fortier, R. G. Blackadar, B. F. Glenister, H. R. Greiner, D. J. McLaren, N. J. McMillan, A. W. Norris, E. F. Roots, J. G.,Souther, R. Thorsteinsson, and E. T. Tozer, Geology of the 
North-Central Part of the Arctic Archipelago, Northwest Territories (Operation Franklin). Geological Survey of Canada Memoir, vol. 320 (1963).

French and Hargraves, 1980 • F. W. French and P. E. Hargraves, Physiological characteristics of plankton diatom resting spores, Marine Biology Letters 1 (1980), pp. 185-195.

Friedman et al., 2003 - M. Friedman, J. A. Tarduno, and D. B. Brinkman, Fossil fishes from the Canadian Arctic: Further palaeobiological evidence for extreme climatic warmth during the Late Cretaceous (Turonian-Coniacian), Cretaceous Research 24 (2003), pp. $615-632$.

Gersonde and Harwood, 1990 - R. Gersonde and D. M. Harwood, Lower Cretaceous diatoms from ODP Leg 113 Site 693 (Weddell Sea). Part 1: Vegetative cells. In: P. F. Barker and J. P. Kennett et al., eds., Proceedings of the Ocean Drilling Program, Scientific Results vol. 113, Ocean Drilling Program, College Station, TX (1990), pp. 365-402.

Gleser, 1962 • S. I. Gleser, Species nova generis Poretzkiae Jouse (Bacillariophyta) e depositionibus Palaeoceni declivitatis Orientalis Montium Uralensium, Botanicheskye material'y otdela sporov'ykh rasteniï 15 (1962), pp. 32-34.

Gleser, 1984 - S. I. Gleser, Znachenie issledovanii po sistematike diatomovykh vodoroslei dl'a biostratigrafii i paleogeografii, Ezhegodnik Vsesoyuznogo Paleontologicheskogo Obshchestva 27 (1984), pp. 284-298 (in Russian).

Gleser et al., 1988 - S. I. Gleser, I. V. Makarova, A. I. Moiseeva, and V. A. Nikolaev, Diatoms of the USSR: Fossil and Recent 2 (1988) fasc. 1. Moskva, Nauka (in Russian).

Gleser et al., 1992 • S. I. Gleser, I. V. Makarova, A. I. Moiseeva, and V. A. Nikolaev, Diatoms of the USSR: Fossil and Recent 2 (1992) fasc. 2. Moskva, Nauka (in Russian).

Gombos, 1976 • A. M. Gombos Jr., Paleogene and Neogene diatoms from the Falkland Plateau and Malvinas Outer Basin: Leg 36, Deep Sea Drilling Project. In: P. F. Barker and I. W. D. Dalziel et al., eds., Initial Reports of the Deep Sea Drilling Project vol. 36, U. S. Government Printing Office, Washington (1976), pp. 575-688.

Grunow, 1879 - A. Grunow, Algen und Diatomeen aus dem Kaspischen Meere, New species and varieties of Diatomaceae from the Caspian Sea, translated with additional notes by F. Kitton, Journal of the Royal Microscopical Society 2 (1879), pp. 677-691.

Grunow, 1884 - A. Grunow, Die Diatomeen von Franz-Josefs Land, Denkschriften der mathematisch-naturwissenshaftlichen Classe der Kaiserlichen Akademie der Wissenschaften 48 (1884), pp. 53-112 (in German)

Hajós and Stradner, 1975 - M. Hajós and H. Stradner, Late Cretaceous archaeomonadaceae, diatomaceae and silicoflagellatae from the South Pacific Ocean, Deep Sea Drilling Project, Leg 29, Site 275. In: J. P. Kennett and R. E. Houtz, eds., Initial Reports of the Deep Sea Drilling Project, 29, U. S. Government Printing Office, Washington (1975), pp. 913-1009.

Hanna, 1927 - G. D. Hanna, Cretaceous diatoms from California, Occasional Papers of the California Academy of Sciences 13 (1927), pp. $1-48$.

Hanna, 1934 - G. D. Hanna, Additional notes on diatoms from the Cretaceous of California, Journal of Paleontology 8 (1934), pp. 352-355.

Hargraves, 1986 - P. E. Hargraves, The relationship of some fossil diatom genera to resting spores. In: M. Ricard, ed., Proceedings of the 8th International Diatom Symposium, Paris, 1984, Koeltz Scientific Books, Koenigstein (1986), pp. 67-80.

Harwood, 1988 - D. M. Harwood, Upper Cretaceous and Lower Paleocene diatom and silicoflagellate biostratigraphy of Seymour Island, eastern Antarctic Peninsula. In: R. M. Feldmann and M. O. Woodburne, eds., Geology and Paleontology of Seymour Island, Antarctic Peninsula, Geological Society of America Memoir vol. 169 (1988), pp. 55-129.

Harwood and Gersonde, 1990 - D. M. Harwood and R. Gersonde, Lower Cretaceous diatoms from ODP Leg 113 site 693 (Weddell Sea). Part 2: Resting spores, chrysophycean cysts, and endoskeletal dinoflagellate, and notes on the origin of diatoms. In: P. F. Barker, J. P. Kennett, et al., eds., Proceedings of the Ocean Drilling Program, Scientific Results vol. 113, Ocean Drilling Program, College Station, TX (1990), pp. 403-425.

Harwood and Nikolaev, 1995 - D. M. Harwood and V. A. Nikolaev, Cretaceous diatoms: morphology, taxonomy, biostratigraphy. In: C. D. Blome et al., eds., Siliceous Microfossils, Paleontological Society
Short Courses vol. 8 (1995), pp. 81-106

Harwood et al., 2007 - D. M. Harwood, V. A. Nikolaev and D. M. Winter, Cretaceous records of diatom evolution, radiation, and expansion. In: S. W. Starrat, Editor, Pond Scum to Carbon Sink. Geological and Environmental Applications of the Diatoms, The Paleontological Society Papers vol. 13 (2007), pp. 33-60.

Hasle and Sims, 1986 • G. R. Hasle and P. A. Sims, The diatom genera Stellarima and Symbolophora, with comments on the genus Actinoptychus, British Phycological Journal 21 (1986), pp. 97-114.

Hasle and Syvertsen, 1985 • G. R. Hasle and E. E. Syvertsen, Thalassiosiropsis, a new diatom genus from the fossil record, Micropaleontology 31 (1985), pp. 82-91.

Hay, 2008 - W. W. Hay, Evolving ideas about the Cretaceous climate and ocean circulation, Cretaceous Research 29 (2008), pp. 725-753.

Herman and Spicer, $1996 \cdot$ A. B. Herman and R. A. Spicer, Palaeobotanical evidence for a warm Cretaceous Arctic Ocean, Nature 380 (1996), pp. 330-333.

Herman and Spicer, 1997 - A. B. Herman and R. A. Spicer, New quantitative palaeoclimate data for the Late Cretaceous Arctic: evidence for a warm polar ocean, Palaeogeography, Palaeoclimatology, Palaeoecology 128 (1997), pp. 227-251.

Homann, 1991 - M. Homann, Die Diatomeen der Fur-Formation (Alttertiär) aus dem Limfjord-Gebiet, Nordjütland/Dänemark, Geologisches Jahrbuch Reihe A, Heft 123, Schweizerbart, Stuttgart (1991).

Ioannides, 1986 - N. S. Ioannides, Dinoflagellate cysts from Upper Cretaceous-Lower Tertiary sections, Bylot and Devon Islands, Arctic Archipelago, Geological Survey of Canada Bulletin 371 (1986), pp. 1-99.

Jenkyns et al., 2004 • H. C. Jenkyns, A. Firster, S. Schouten and J. S. Sinninghe Damste, High temperatures in the Late Cretaceous Arctic Ocean, Nature 432 (2004), pp. 888-892.

Jordan and Ito, 2002 - R. W. Jordan and R. Ito, Observations on Proboscia species from Late Cretaceous sediments, and their possible evolution from Kreagra. In: J. John, ed., Proceedings of the 15th International Diatom Symposium. Liechtenstein, A. R. G. Gantner Verlag K. G., Ruggell (2002), pp. 313-329.

Jousé, 1949 - A. P. Jousé, Algae diatomaceae aetatis supernecretaceae ex arenis argillaceis systematis fluminis Bolschoy Aktay in declivitate Orientali Ural Borealis, Botanicheskye material'y otdela sporov'ykh rastenii 6 (1949), pp. 65-78 (in Russian).

Jousé, 1951 - A. P. Jousé, Diatomeae et silicoflagellatae aetatis Cretae Superne e montibus Uralensibus Septentrionalibus, Botanicheskye material'y otdela sporov'ykh rasteniï 7 (1951), pp. 42-65 (in Russian).

Jousé, 1955 - A. P. Jousé, Species novae generis Gladius Schulz in stratura aetatis Cretaceae superioris, Botanicheskye material'y otdela sporov'ykh rasteniï 10 (1955), pp. 72-76 (in Russian).

Kemp et al., 2000 - A. E. S. Kemp, J. Pike, R. B. Pearce, and C. B. Lange, The 'Fall dump' - a new perspective on the role of a 'shade flora' in the annual cycle of diatom production and export flux, Deep-Sea Research II 47 (2000), pp. 2129-2154.

Kidder and Erwin, 2001 - D. L. Kidder and D. H. Erwin, Secular distribution of biogenic silica through the Phanerozoic: comparison of silica-replaced fossils and bedded cherts at the series level, Journal of Geology 109 (2001), pp. 509-522.

Kitchell et al., 1986 • J. A. Kitchell, D. L. Clark, and A. M. Gombos Jr., Biological selectivity of extinction: a link between background and mass extinction, Palaios 1 (1986), pp. 504-511.

Krotov and Schibkova, 1959 - A. I. Krotov and K. G. Schibkova, Species novae diatomacearum e sedimentis Cretae superioris in mintibus Uralensibus, Botanicheskye material'y otdela sporov'yh rasteniï $\mathbf{1 2}$ (1959), pp. 112-129 (in Russian).

Kuhnt et al., 2005 - W. Kuhnt, S. Hess, A. Holbourn, H. Paulsen, and B. Salomon, The impact of the $1991 \mathrm{Mt}$. Pinatubo eruption on deep-sea foraminiferal communities: A model for the CretaceousTertiary boundary?, Palaeogeography, Palaeoclimatology, Palaeoecology 224 (2005), pp. 83-107.

Lerbekmo and Braman, 2002 - J. F. Lerbekmo and D. R. Braman, Magnetostratigraphic and biostratigraphic correlation of late Campanian and Maastrichtian marine and continental strata from the Red Deer Valley to the Cypress Hills, Alberta, Canada, Canadian Journal of Earth Sciences 39 (2002), pp. 539-557.

Littke et al., 1991 - R. Littke, E. Fourtanier, J. Thurow and E. Taylor, Silica diagenesis and its effect on lithification of Broken Ridge deposits, Central Indian Ocean. In: J. Weissel, J. Peirce, E. Taylor, J. Alt, et al., eds., Proceedings of the Ocean Drilling Program, Scientific Results vol. 121, Ocean Drilling Program, College Station, TX 
(1991), pp. 261-272.

Magavern et al., 1996 - S. Magavern, D. L. Clark and S. L. Clark, ${ }^{87 / 86} \mathrm{Sr}$, phytoplankton, and the nature of the Late Cretaceous and Early Cenozoic Arctic Ocean, Marine Geology 133 (1996), pp. 183-192.

Mann, 1999 - D. G. Mann, The species concept in diatoms, Phycologia 38 (1999), pp. 437-495.

Mayr et al., 1998 - U. Mayr, de T. Freitas, B. Beauchamp, and G. Eisbacher, eds., The geology of Devon Island north of $76^{\circ}$, Canadian Arctic Archipelago, Geological Survey of Canada Bulletin vol. 526 (1998), pp. 1-500.

McCartney et al., in press - K. McCartney, J. Witkowski, and D. M. Harwood, Unusual assemblages of Late Cretaceous silicoflagellates from the Canadian Archipelago. Revue de micropaléontologie, in press.

McQuoid and Nordberg, 2003 - M. R. McQuoid and K. Nordberg, The diatom Paralia sulcata as an environmental indicator species in coastal sediments, Estuarine, Coastal and Shelf Science 56 (2003), pp. 339-354.

Miall, 1979 - A. D. Miall, Mesozoic and Tertiary geology of Banks Island, Arctic Canada: The history of an unstable craton margin. Geological Survey of Canada Memoir, vol. 387 (1979), pp. 1-235.

Miall, 1991 - A. D. Miall, Late Cretaceous and Tertiary basin development and sedimentation, Arctic Islands. In: H. P. Trettin, ed., Geology of the Innuitian Orogen and Arctic Platform of Canada and Greenland. Geological Survey of Canada, Geology of Canada vol. 3 (1991), pp. 437-458.

Nikolaev and Harwood, 2007 - V. A. Nikolaev and D. M. Harwood, New taxa of extinct diatoms (Bacillariophyta) from Antarctic, Novosti sistematiki nizshikh rasteniï 41 (2007), pp. 59-69 (in Russian).

Nikolaev et al., $2001 \cdot$ V. A. Nikolaev, J. P. Kociolek, E. Fourtanier, J. A. Barron, and D. M. Harwood, Late Cretaceous diatoms (Bacillariophyceae) from the Marca Shale member of the Moreno Formation, California, Occasional Papers of the California Academy of Sciences 152 (2001), pp. 1-89.

Núñez-Betelu et al., 1995a • L. K. Núñez-Betelu, L. V. Hills, F. F. Krause, and D. J. McIntyre, Upper Cretaceous paleoshorelines of the northeastern Sverdrup Basin, Ellesmere Island, Canadian Arctic Archipelago. In: K. V. Simakov and D. K. Thurston, eds., Proceedings of the 1994 International Conference on Arctic Margins, Magadan, Russia (1995), pp. 43-49.

Núñez-Betelu et al., 1995b • L. K. Núñez-Betelu, L. V. Hills, and R. A. MacRae, Palynostratigraphy and hydrocarbon potential of the Upper Cretaceous Kanguk Formation: an integrated multidisciplinary analysis of the Northeastern Canadian Arctic Archipelago. In: K. V. Simakov and D. K. Thurston, eds., Proceedings of the 1994 International Conference on Arctic Margins, Magadan, Russia (1995), pp. 54-61.

Olshtynskaya, 1990 - A. Olshtynskaya, Morphology of the diatom genus Pseudopodosira. In: H. Simola, Editor, Proceedings of the Tenth International Diatom Symposium, Koeltz Scientific Books, Koenigstein (1990), pp. 93-103.

Pantocsek, 1886 • Pantocsek, J., 1886. Beiträge zur Kenntnis der Fossilen Bacillarien Ungarns. I. Theil: Marine Bacillarien. Platzko, J., Nagy-Tapolcsány (in German).

Pantocsek, 1889 • Pantocsek, J., 1889. Beiträge zur Kenntnis der Fossilen Bacillarien Ungarns. II Theil: Brackwasser Bacillarien. Platzko, J., Nagy-Tapolcsány (in German).

Rao et al., 1995 - V. P. Rao, M. Thamban and M. Lamboy, Verdine and glaucony facies from surficial sediments of the eastern continental margin of India, Marine Geology 127 (1995), pp. 105-113.

Ricketts and Stephenson, 1994 - B. D. Ricketts and R. A. Stephenson, The demise of Sverdrup Basin: Late Cretaceous-Paleogene sequence stratigraphy and forward modeling, Journal of Sedimentary Research B64 (1994), pp. 516-530.

Rigby et al., 2007 - J. K. Rigby, K. Chin, J. D. Bloch, and J. S. Tweet, A new hexactinellid sponge from the Cretaceous of Devon Island, Canadian High Arctic, Canadian Journal of Earth Science 44 (2007), pp. 1235-1242.

Ross et al., 1977 - R. Ross, P. A. Sims, and G. R. Hasle, Observations on some species of the Hemiauloideae. In: R. Simonsen, Editor, Fourth Symposium on Recent and Fossil Diatoms, Nova Hedwigia Beiheft vol. 54 (1977), pp. 179-213.

Ross and Sims, 1985 - R. Ross and P. A. Sims, Some genera of the Biddulphiaceae (diatoms) with interlocking linking spines, Bulletin of the British Museum (Natural History) 13 (1985), pp. 277-381.
Round et al., 1990 • F. E. Round, R. M. Crawford, and D. G. Mann, The Diatoms: Biology and Morphology of the Genera, Cambridge University Press (1990)

Schmidt et al., 1874-1959 • A. Schmidt, M. Schmidt, F. Fricke, H. Heiden, O. Müller, and F. Hustedt, Atlas der Diatomaceen-kunde. Leipzig-Berlin; Reprint 1984, Koeltz Scientific Books, Koenigstein (1874-1959) (in German)

Schrader and Gersonde, 1978 - H. -J. Schrader and R. Gersonde, Diatoms and silicoflagellates. In: W. J. Zachariasse, ed., Micropaleontological Counting Methods and Techniques: An Exercise of an Eight Metres Section of the Lower Pliocene of Cap Rossello, Sicily, Utrecht Micropalaeontological Bulletin 17 (1978), pp. 129-176.

Schulz, 1935 - P. Schulz, Diatomeen aus senon Schwammgesteinen der Danziger Bucht. Zaugleich ein Beitrag zur Entwicklungsgeschichte der Diatomeen, Botanisches Archiv 37 (1935), pp. 383-414 (in German).

Sheshukova-Poretzkaya and Gleser, 1964 • V. S. Sheshukova-Poretzkaya and S. I. Gleser, Diatomeae marinae novae e Paleogeno Ucrainiae, Novosti sistematiki nizshikh rasteniï 1 (1964), pp. 78-92 (in Russian).

Shipboard Scientific Party, 1989 • Shipboard Scientific Party, Site 748 In: R. Schlich, S. W. Wise Jr., et al., eds., Proceedings of the Ocean Drilling Program, Initial Results vol. 120, Ocean Drilling Program, College Station, TX (1989), pp. 157-235.

Sims, 1986 • P. A. Sims, Sphynctolethus Hanna, Ailuretta gen. nov., and evolutionary trends within the Hemiauloideae, Diatom Research $\mathbf{1}$ (1986), pp. 241-269.

Sims, 1998 - P. A. Sims, The early history of the Biddulphiales. I. The genus Medlinia gen. nov, Diatom Research 13 (1998), pp. 337-374.

Sims and Crawford, 2002 • P. A. Sims and R. M. Crawford, The morphology and taxonomy of the marine centric diatom genus Paralia. II. Paralia crenulata, P. fausta and the new species, P. hendeyi, Diatom Research 17 (2002), pp. 363-382.

Sims and Crawford, 2007 • P. A. Sims and R. M. Crawford, The fossil diatom genus Truania Pantocsek and its relationship with Ellerbeckia Crawford, Diatom Research 22 (2007), pp. 195-207.

Sims and Mahood, 1998 - P. A. Sims and A. D. Mahood, Vulcanella hannae Sims and Mahood, gen. et sp. nov., with a discussion of the genera Tumulopsis Hendey, Acanthodiscus Pantocsek, Poretzkia Jousé and Goniothecium Ehrenberg, Diatom Research 13 (1998), pp. 113-131.

Sims et al., 2006 • P. A. Sims, D. G. Mann, and L. K. Medlin, Evolution of the diatoms: Insights from fossil, biological and molecular data, Phycologia 45 (2006), pp. 361-402.

Spicer and Herman, 2010 - R. A. Spicer and A. B. Herman, The Late Cretaceous environment of the Arctic: A quantitative reassessment based on plant fossils, Palaeogeography, Palaeoclimatology, Palaeoecology 295 (2010), 423-442.

Stein, 2008 - R. Stein, Mesozoic to Cenozoic paleoenvironmental records of high northern latitudes. In: R. Stein, ed., Arctic Ocean Sediments: Processes, Proxies, and Paleoenvironments, Elsevier, Amsterdam (2008), pp. 439-496.

Strelnikova, $1966 \cdot$ N. I. Strelnikova, Revisio specierum generum Gladius Schulz et Pyxilla Grev. (Bacillariophyta) e sedimentis Cretae superioris, Novosti sistematiki nizshikh rasteniï (1966), pp. 23-36 (in Russian).

Strelnikova, 1971 - N. I. Strelnikova, Species novae bacillariophytorum e sedimentis Cretae posterioris in declivitate orientali partis polaris ac praepolaris montium Uralensium, Novosti sistematiki nizshikh rastenii 8 (1971), pp. 41-50 (in Russian).

Strelnikova, 1974 - N. I. Strelnikova, Diatomei pozdnego mela, Izdatel'stoo "Nauka", Moskva (1974) (in Russian).

Strelnikova, 1975 - N. I. Strelnikova, Diatoms of the Cretaceous period. In: R. Simonsen, ed., Third Symposium on Recent and Fossil Diatoms, Nova Hedwigia Beiheft vol. 53 (1975), pp. 311-321.

Strelnikova, 1990 - N. I. Strelnikova, Evolution of diatoms during the Cretaceous and Paleogene periods. In: H. Simola, Editor, Proceedings of the 10th International Diatom Symposium, Koeltz Scientific Books, Koenigstein (1990), pp. 195-204.

Suto et al., 2009 - I. Suto, R. W. Jordan, and M. Watanabe, Taxonomy of middle Eocene diatom resting spores and their allied taxa from the central Arctic Basin, Micropaleontology 55 (2009), pp. 259-312.

Tapia and Harwood, 2002 • P. M. Tapia and D. M. Harwood, Upper Cretaceous diatom biostratigraphy of the Arctic archipelago and northern continental margin, Canada, Micropaleontology 48 (2002), pp. 303-342. 
Tappan, $\mathbf{1 9 8 0}$ - H. N. Tappan, Paleobiology of Plant Protists, W. H. Freeman, San Francisco (1980).

Tarduno et al., 1998 - J. A. Tarduno, D. B. Brinkman, P. R. Renne, R. D. Cottrell, H. Scher and P. Castillo, Evidence for extreme climatic warmth from Late Cretaceous arctic vertebrates, Science $\mathbf{2 8 2}$ (1998), pp. 2241-2244.

Thorsteinsson and Mayr, 1987 - R. Thorsteinsson and U. Mayr, The sedimentary rocks of Devon Island, Canadian Arctic Archipelago, Geological Survey of Canada Memoir, vol. 411 (1987).

Tiffany, 2008 - M. Tiffany, Valve development in Aulacodiscus, Diatom Research 23 (2008), pp. 185-212.

Tomsich et al., in press - C. S. Tomsich, P. J. McCarthy, S. J. Fowell, and D. Sunderlin, Paleofloristic and paleoenvironmental information from a Late Cretaceous (Maastrichtian) flora of the lower Cantwell Formation near Sable Mountain, Denali National Park, Alaska, Palaeogeography, Palaeoclimatology, Palaeoecology 295, 389-408.

Tozer, $1961 \cdot$ E. T. Tozer, Summary account of Mesozoic and tertiary stratigraphy, Canadian Arctic Archipelago. In: G. O. Raasch, ed., Geology of the Arctic, Alberta Society of Petroleum Geologists, vol. 1 (1961), pp. 381-402.

Witt, 1886 • O. N. Witt, Ueber den Polierschierfer von ArchangelskKurojedowo im Gouv, Simbirsk. Verhandlungen der Russisch-kaiserlichen mineralogischen Gesselschaft zu St. Petersburg Serie II 22 (1886), pp. 137-177 (in German).

Zielinski and Gersonde, 1997 - U. Zielinski and R. Gersonde, Diatom distribution in Southern Ocean surface sediments (Atlantic sector): Implications for paleoenvironmental reconstructions, Palaeogeography, Palaeoclimatology, Palaeoecology 129 (1997), pp. 213-250.

\section{Appendix}

An alphabetic listing of taxa found in the Devon Island deposit is given below. For synonymy of taxa, and descriptions of the informal taxa used here please refer to the supplementary material.

\section{Alphabetical listing of taxa}

Actinodictyon sp. aff. A. antiquorum Pantocsek, 1889

Actinoptychus simbirskianus Schmidt, 1875

Actinoptychus tenuis Strelnikova, 1974

Amblypyrgus sp. A

Archepyrgus sp. aff. A. melosiroides Gersonde and Harwood, 1990

Aulacodiscus sp. cf. A. insignis Hustedt in Schmidt et al., 1944

Aulacodiscus septus Schmidt, 1876

Basilicostephanus sp. 1 Tapia and Harwood, 2002

Briggera includens (Grunow) Ross and Sims, 1985

Briggera ornitocephala (Greville) Ross and Sims, 1985

Chasea bicornis Hanna, 1934

Cladogramma sp. cf. C. simplex Hajós and Stradner, 1975

Cortinocornus rossicus (Pantocsek) Gleser, 1984

Cortinocornus? sp. A

Coscinodiscus polymorphus Strelnikova, 1974

Costopyxis antiqua (Jousé) Gleser, 1984

Costopyxis schulzii (Steinecke ex Schulz) Gleser, 1984

Costopyxis schulzii (Steinecke ex Schulz) Gleser f. ornata (Schulz) Strelnikova in Gleser et al., 1988

Dasyangea dactylethra Harwood and Gersonde, 1990

Gladiopsis pacifica (Hajós and Stradner) Gersonde and Harwood, 1990

Gladiopsis sp. A

Gladiopsis speciosa (Schulz) Gersonde and Harwood f. aculeolata Strelnikova, 1966

Gladiopsis speciosa (Schulz) Gersonde and Harwood f. porata Strelnikova, 1966

Gladiopsis speciosa (Schulz) Gersonde and Harwood f. speciosa

Gladius antiquus Forti and Schulz, 1932

Goniothecium odontellum Ehrenberg 1844 sensu Strelnikova, 1974

Hemiaulus altus Hajós in Hajós and Stradner, 1975

Hemiaulus antiquus Jousé, 1951

Hemiaulus asymmetricus Jousé, 1951
Hemiaulus curvatulus Strelnikova, 1971

Hemiaulus echinulatus Jousé, 1951

Hemiaulus elegans (Heiberg) Grunow, 1884

Hemiaulus hostilis Heiberg sensu Harwood, 1988

Hemiaulus hostilis Heiberg sensu Strelnikova, 1974

Hemiaulus polymorphus Grunow, 1884

Hemiaulus polymorphus var. frigida Grunow, 1884

Hemiaulus sp. cf. H. inaequilaterus Gombos, 1976

Hemiaulus speciosus Jousé, 1951

Hemiaulus sporalis Strelnikova, 1971

Hemiaulus? sp. A

Hemiaulus? sp. B

Hyalodiscus nobilis Pantocsek, 1889

Hyalodiscus radiatus (O'Meara) Grunow, 1879

Incisoria lanceolata Hajós and Stradner, 1975

Lepidodiscus elegans Witt, 1886

Medlinia deciusii (Hanna) Nikolaev et al., 2001

Medlinia fenestrata (Witt) Sims, 1998

Medlinia weissei (Grunow in Schmidt et al.) Sims, 1998

Odontotropis carinata Grunow, 1884

Odontotropis cristata Grunow, 1884

Paralia crenulata (Grunow) Gleser in Gleser et al. 1992

Paralia fausta (Schmidt) Sims and Crawford, 2002

Paralia ornata (Grunow) Grunow ex van Heurck, 1882

Paralia sulcata (Ehrenberg) Cleve, 1873

Poretzkia sp. cf. P. umbonata Gleser, 1962

Proboscia unicornis Jordan and Ito, 1998

Pseudoaulacodiscus sp. A

Pseudopodosira reticulata Strelnikova, 1974

Pseudopodosira westii (Smith) Sheshukova-Poretzkaya and Gleser, 1964

Pseudopyxilla aculeata Jousé, 1951

Pseudopyxilla americana (Ehrenberg) Forti, 1909

Pseudopyxilla sp. A

Pseudopyxilla sp. B

Pterotheca aculeifera Grunow in Van Heurck, 1880-1885

Pterotheca alata Strelnikova, 1971

Pterotheca clavata Strelnikova, 1974

Pterotheca evermanni Hanna, 1927

Pterotheca simplex Strelnikova, 1971

Pterotheca sp. A

"Pterotheca? sp." Strelnikova, 1974

Pyrgodiscus triangulatus Hajós and Stradner, 1975

Rhizosolenia dubia (Grunow) Homann, 1991

Sceptroneis dimorpha Strelnikova, 1974

Sceptroneis sp. cf. S. gracilis Hajós in Hajós and Stradner, 1975

Sheshukovia excavata (Heiberg) Nikolaev and Harwood in Nikolaev et al., 2001

Sphynctolethus hemiauloides Sims, 1986

Stellarima steinyi (Hanna) Hasle and Sims, 1986

Stephanopyxis barbadensis (Greville) Grunow, 1884

Stephanopyxis dissonus (Schulz) Strelnikova and Nikolaev in

Gleser et al., 1988

Stephanopyxis grunowii Grove and Sturt in Schmidt et al., 1888

Thalassiosiropsidella simsii Nikolaev and Harwood, 2007

Thalassiosiropsis wittiana (Pantocsek) Hasle in Hasle and Syvertsen, 1985

Trinacria indefinita Jousé, 1951

Trochosiropsis polychaeta (Strelnikova) Tapia and Harwood, 2002

Truania archangelskiana Pantocsek, 1886

Unknown genus and species \#1

Unknown genus and species \#2

Unknown genus and species \#3

Unknown genus and species \#4 


\section{Appendix - Supplementary Material}

\section{TAXONOMIC LIST}

Genus Actinodictyon Pantocsek 1889

Actinodictyon sp. aff. A. antiquorum Pantocsek 1889 [Fig. 6C-D]

1889 Actinodictyon antiquorum Pantocsek; Pantocsek, pl. X, fig. 176

1974 Actinodictyon weissflogii Pantocsek; Strelnikova, pro parte, p. 72, pl. XVIII, figs. 2a,b

1997 Actinodictyon antiquorum Pantocsek; Ross \& Sims, p. 327, figs. 10-13

Genus Actinoptychus Ehrenberg 1843

A. simbirskianus Schmidt 1875

1875 Actinoptychus simbirskianus Schmidt; Schmidt et al., pl. 29, fig. 11

1886 Actinoptychus simbirskianus Schmidt; Schmidt et al., pl. 109, figs. 3-8

1889 Actinoptychus simbirskianus Schmidt; Pantocsek, pl. XX, fig. 307

1974 Actinoptychus simbirskianus Schmidt; Strelnikova, p. 68, pl. XV, figs. 1-7b

1985 Actinoptychus simbirskianus Schmidt; Barron, pl. 10.1, fig. 8

1994 Actinoptychus simbirskianus Schmidt; Dell'Agnese and Clark, fig. 3.1

2002 Actinoptychus simbirskianus Schmidt; Tapia and Harwood, p. 318, pl. III, figs. 9-10

A. tenuis Strelnikova 1974 [Fig. 6K] 
1974 Actinoptychus tenuis Strelnikova; Strelnikova, p. 67, pl. XIV, figs. 1-4

1994 Actinoptychus tenuis Strelnikova; Dell'Agnese and Clark, p. 38, fig. 3.2

2002 Actinoptychus tenuis Strelnikova; Tapia and Harwood, p. 318, pl. VII, fig. 1

Genus Amblypyrgus Gersonde et Harwood 1990

Amblypyrgus sp. A [Fig. 6N-O]

Description: Valves cylindrical, small (less than $10 \mu \mathrm{m}$ ). Valve face convex, with linking spines located in the center. Hyaline margin of the mantle.

Genus Archepyrgus Gersonde et Harwood 1990

Archepyrgus sp. aff. A. melosiroides Gersonde et Harwood 1990 [Fig. 6L-M]

1990 Archepyrgus melosiroides Gersonde et Harwood; Gersonde and Harwood, p. 370, pl.

10, figs. $2-6,14,15$; pl. 13 , figs. $13-18$

2001 Archepyrgus melosiroides Gersonde et Harwood; Nikolaev et al., p. 30, pl. XVI, figs. $3-5$

2006 Archepyrgus melosiroides Gersonde et Harwood; Sims et al., fig. 16

2008 Archepyrgus; Crawford and Sims, pl. 1, fig. 2

Genus Aulacodiscus Ehrenberg 1844 
Aulacodiscus sp. cf. A. insignis Hustedt 1944 [Fig. 7A-B; Fig. 11A]

1944 Aulacodiscus insignis Hustedt; Schmidt et al, pl. 458, figs. 4-5

Remarks: Most frequently found only as isolated inflations with tube processes.

A. septus Schmidt 1876

1876 Aulacodiscus septus Schmidt; Schmidt et al., pl. 36, figs. 19-21

1974 Aulacodiscus septus f. septus (Schmidt) Strelnikova; Strelnikova, p. 77, pl. XIX, figs. $1-6 a, b$

2002 Aulacodiscus septus f. septus (Schmidt) Strelnikova; Tapia and Harwood, p. 319, pl. VII, fig. 3

2004 Aulacodiscus septus Schmidt; Strelnikova et al., p. 288, figs. 9-14, 84, 85

Genus Basilicostephanus Gersonde et Harwood 1990

Basilicostephanus sp. 1 Tapia et Harwood 2002

2002 Basilicostephanus sp. 1 Tapia et Harwood; Tapia and Harwood, p. 319, pl. I, figs. 7-8, pl. II, figs. 2-4

Genus Briggera Ross et Sims 1985

B. includens (Grunow) Ross et Sims 1985 [Fig. 9A] 
1974 Hemiaulus includens (Ehrenberg) Grunow: Strelnikova, p. 101 pl. XLVIII, figs. 1-6, 1985 Briggera includens (Grunow) Ross et Sims: Ross and Sims, p. 294. pl. 1, figs. 1-9

B. ornitocephala (Greville) Ross et Sims 1985

1865 Hemiaulus ornitocephalus Greville; Greville, XV, p. 32, pl. III, fig. 16

1888 Hemiaulus ornitocephalus Greville; Schmidt et al., pl. 142, figs. 34, 36, 37

1985 Briggera ornitocephala (Greville) Ross et Sims; Ross and Sims, p. 309, pl. 10-12

Genus Chasea Hanna 1934

C. bicornis Hanna 1934 [Fig. 10J]

1934 Chasea bicornis Hanna; Hanna, p. 354, pl. 48, figs. 12-16

1975 Chasea bicornis Hanna; Hajós and Stradner, p. 928, pl. 5, figs. 1-3

1988 Chasea bicornis Hanna; Harwood, p. 80, figs. 10.1-10.2

Genus Cladogramma Ehrenberg 1854

Cladogramma sp. cf. C. simplex Hajós et Stradner 1975

1975 Cladogramma simplex Hajós et Stradner; Hajós and Stradner, p. 928, pl. 4, fig. 7-8 
C. rossicus (Pantocsek) Gleser 1984

- first morphotype [Fig. 8A-B, H, R-S; Fig. 12A-B]

1884 Hemiaulus polycystinorum var. simbirskianus Grunow; Grunow, pl. II(B), figs. 44, 45

1886 Hemiaulus antarcticus Weisse; Witt, pl. VI, figs. 1-2

1888 Hemiaulus antarcticus Weisse; Schmidt et al., pl. 144, figs. 30-35

1974 Hemiaulus rossicus Pantocsek; Strelnikova, pl. XLIII, figs. 1-10

1974 Hemiaulus rossicus Pantocsek; Gleser et al., pl. XI, fig. 6

1977 Hemiaulus rossicus Pantocsek; Ross, Sims and Hasle, p. 195, pl. 8, figs. 48-50

1984 Cortinocornus rossicus (Pantocsek) Gleser; Gleser, p. 290

2002 Cortinocornus rossicus (Pantocsek) Gleser; Tapia and Harwood, p. 390, pl. III, figs. 58

2002 Hemiaulus sp. A: Tapia and Harwood, pl. III, figs. 1-2

not 2006 Hemiaulus rossicus Pantocsek; Davies, p. 238, pl. 8, fig. 5-6

Remarks: Specimens having relatively high elevations and a rimoportule associated with an external tube were identified as first morphotype. Cortinocornus appears to be one of the most common diatoms of the Late Cretaceous. A revision of the genus is necessary because of considerable taxonomic confusion.

- second morhotype [Fig. 8C-E; Fig. 12C-D]

1951 Hemiaulus polycystinorum var. brevicornis Jousé; Jousé, p. 54, pl. IV, figs. 1a-d

1988 Hemiaulus rossicus Pantocsek; Harwood, p. 83, figs. 14.18, 14.21 
Remarks: Valves having low, or no discernible elevations, and an external slit associated with the rimoportule were identified as second morphotype.

Cortinocornus? sp. A [Fig. 8F, M-N; Fig. 12E]

Description: Frustules homovalvate. Valves elongate, $15-40 \mu \mathrm{m}$ long, flat, broader in the center than in the apical parts, with a deep $(12 \mu \mathrm{m})$ mantle, perpendicular to the valve face. Mantle margin serrated. Ca. 7-9 poroid areolae in $10 \mu \mathrm{m}$, arranged in more or less vertical rows on the mantle, perforations of the valve face sparser and smaller. Two internal pseudosepta, dividing the valve into 'chambers'.

Remarks: No means of sibling valve attachment observed, no processes found. For this reason the generic affiliation is tentative.

Genus Coscinodiscus Ehrenberg 1839

C. polymorphus Strelnikova 1974

1974 Coscinodiscus polymorphus Strelnikova; Strelnikova, p. 65, pl. III, figs. 8-17

Genus Costopyxis Gleser 1984

C. antiqua (Jousé) Gleser 1984 [Fig. 7G; Fig. 11L]

1951 Stephanopyxis antiquus Jousé; Jousé, p. 46, pl. I, figs. 3 a,b 
1951 Stephanopyxis cancellatus Jousé; Jousé, p. 46, pl. I, figs. 4 a,b

1974 Stephanopyxis antiqua Jousé; Strelnikova, p. 56, pl. III, figs. 18-20

1985 Stephanopyxis antiqua Jousé; Fenner, p. 768, fig. 14.13;

1988 Costopyxis antiqua (Jousé) Gleser; Gleser et al., pl. 31, figs. 1-3,6

2002 Costopyxis antiqua (Jousé) Gleser; Tapia and Harwood, 319, pl. II, figs. 10-11, 14-15

C. schulzii (Steinecke ex Schulz) Gleser 1984 [Fig. 7E-F, M-N; Fig. 11K]

1949 Stephanopyxis schulzii Steinecke ex Schulz; Jousé, p. 65, pl. I, figs. 2-3

1974 Stephanopyxis schulzii Steinecke ex Schulz f. schulzii Strelnikova; Strelnikova, p. 55, pl. IV, figs. $1-3,8$

1974 Stephanopyxis schulzii Steinecke ex Schulz f. nuda Strelnikova; Strelnikova, p. 55, pl. IV, figs. 10-12

2002 Costopyxis schulzii (Steinecke) Gleser; Tapia and Harwood, p. 324, pl. II, figs. 6-7

C. schulzii (Steinecke ex Schulz) Gleser f. ornata (Schulz) Strelnikova 1988 [Fig. $11 \mathrm{~J}]$

1974 Stephanopyxis ornata Schulz; Strelnikova, p. 56, pl. IV, figs. 4-7, 9 a,b

1985 Stephanopyxis ornata Schulz; Fenner, p. 738, fig. 14.7

1988 Costopyxis schulzii (Steinecke) Gleser f. ornata (Schulz) Strelnikova; Gleser et al., pl. 32, figs. 9-16

2002 Costopyxis ornata (Schulz) Strelnikova: Tapia and Harwood, 319, pl. I, figs. 15-16

Remarks: Tapia and Harwood (2002) list this variety as a separate species. 
Genus Dasyangea Harwood et Gersonde 1990

D. dactylethra Harwood et Gersonde 1990 [Fig. 10K, Y-Z]

1990 Dasyangea dactylethra Harwood et Gersonde; Harwood and Gersonde, p. 409, pl. 2, figs. $1-7$

Remarks: This study is the first record of D. dactylethra in the Upper Cretaceous.

Genus Gladiopsis Gersonde et Harwood 1990

G. pacifica (Hajós et Stradner) Gersonde et Harwood 1990

1975 Gladius pacificus Hajós et Stradner; Hajós and Stradner, p. 933, pl. 11, fig. 13

1985 Gladius pacificus Hajós et Stradner; Barron, p. 141, pl. 10.2, fig. 15

1994 Gladiopsis pacificus (Hajós); Dell’Agnese and Clark, fig. 3.7

Gladiopsis sp. A [Fig. 10H]

Description: Valves cylindrical, long, curved. Areolae arranged spirally about the long axis. Tube process of unknown nature at the apex of the valve.

Remarks: Only broken valves up to ca. $140 \mu \mathrm{m}$ seen. Possibly a teratoid form of G. speciosa (Schulz) Gersonde et Harwood f. poratus Strelnikova. 
G. speciosa (Schulz) Gersonde et Harwood f. aculeolata Strelnikova 1966

1966 Pyxilla speciosa (Schulz) Strelnikova f. aculeolata Strelnikova; Strelnikova, p. 35, pl. IV, figs. 3,4,11

1974 Gladius speciosus Schulz f. aculeolatus Strelnikova; Strelnikova, p. 105, pl. LI, figs. $5,6,7-10$

2002 Gladopsis speciosus f. aculeolatus Strelnikova; Tapia and Harwood, p. 324, pl. III, figs. 3,4

G. speciosa (Schulz) Gersonde et Harwood f. porata Strelnikova 1966 [Fig. 7S; Fig. $11 \mathrm{C}]$

1966 Pyxilla speciosa (Schulz) Strelnikova f. porata Strelnikova; Strelnikova, p. 35, pl. IV, figs. $5,6,12$

1974 Gladius speciosus Schulz f. poratus Strelnikova; Strelnikova, p. 106, pl. XLIX, fig. 22, pl. LI, figs 11-12

2002 Gladiopsis speciosus f. poratus Strelnikova; Tapia and Harwood, p. 324, pl. II, fig.1, pl. V, figs. 1-4

G. speciosa (Schulz) Gersonde et Harwood f. speciosa

1935 Gladius speciosus Schulz; Schulz, p. 391, pl. II, figs. 6-8

1955 Gladius speciosus Schulz; Jousé, p. 76, fig. 4

1966 Pyxilla speciosa (Schulz) Strelnikova f. speciosa; Strelnikova, pp. 33-34, pl. I, II, pl. III, figs. 5-9, pl. IV, figs. 1-2, 10 
1974 Gladius speciosus Schulz f. speciosus; Strelnikova, p. 104, pl. L, figs. 1-19

1985 Gladius speciosus Schulz f. speciosus; Barron, p. 141, pl. 10.2, fig. 14

1988 Gladius speciosus Schulz f. speciosus; Gleser et al., pl. 36, figs. 1-3,6,7,10

1990 Gladiopsis speciosa (Schulz) Gersonde et Harwood; Gersonde and Harwood, p. 372

1994 Gladiopsis speciosa (Schulz) Gersonde et Harwood; Sims, figs. 43-48

2001 Gladiopsis speciosa (Schulz) Gersonde et Harwood; Nikolaev et al., p. 12, pl. 2, fig. 7

2002 Gladiopsis speciosus f. speciosus (Schulz) Strelnikova; Tapia and Harwood, p. 324, pl. II, fig. 1

Remarks: Strelnikova (1966 and 1974) used the names 'Pyxilla speciosa Schulz f. speciosa' and 'Gladius speciosus Schulz f. speciosus' respectively, not mentioning the creator of the discussed form to indicate the variety originally described by Schulz (1935). Gersonde and Harwood (1990) kept the form speciosa (feminine) as the specific epithet, instead of the original masculine speciosus. Hendey (1993), Sims (1994) and the Catalogue of Diatom Names (Fourtanier and Kociolek 2007) indicated Gladiopsis speciosa as the valid name for the species, while Tapia and Harwood (2002) retained the masculine specific epithet.

Genus Gladius Forti et Schulz 1932

G. antiquus Forti et Schulz 1932 [Fig. 7Q-R]

1932 Gladius antiquus Forti et Schulz; Forti and Schulz, p. 242, text-fig. 3, pl. III, fig. 6

1990 Gladius antiquus Forti et Schulz; Gersonde and Harwood, p. 373, pl. 7, figs. 1-2, pl. 8, figs. $1,2,5,6$, pl. 15 , figs. $6-7$, pl. 17, fig. 12 
2001 Gladius antiquus Forti et Schulz; Nikolaev et al., p. 22, pl. IX, figs. 1-5

2002 Gladius antiquus Forti et Schulz; Tapia and Harwood, p. 324, pl. I, fig. 2

2006 Gladius antiquus Forti et Schulz; Sims et al., figs. 11-12

2008 Gladius; Crawford and Sims, pl. 1, fig. 4

Genus Goniothecium Ehrenberg 1843

G.odontellum Ehrenberg 1844 sensu Strelnikova 1974 [Fig. 12P]

1951 Goniothecium odontella Ehrenberg; Jousé, p. 60, pl. V, figs. 1-7

1974 Goniothecium odontellum Ehrenberg; Strelnikova, p. 116, pl. LV, fig. 1-3,5-10

1975 Goniothecium odontella Ehrenberg; Hajós and Stradner, p. 935, pl. 10, figs. 11-12

1985 Goniothecium odontella Ehrenberg; Barron, pl. 10.2, fig. 13

1988 Goniothecium odontella Ehrenberg; Harwood, p. 82, figs. 10.21-22

1994 Goniothecium odontella Ehrenberg; Dell'Agnese and Clark, p. 38, fig. 3.8

1998 Goniothecium odontellum Ehrenberg sensu Strelnikova; Sims and Mahood, figs. 26-31

2006 Goniothecium odontella Ehrenberg; Davies, p. 52, pl. 17, fig. 7-8.

Genus Hemiaulus Ehrenberg 1844

H. altus Hajós 1975

1975 Hemiaulus altus Hajós; Hajós and Stradner, p. 931, pl. 5, figs. 17-19

1985 Hemiaulus altus Hajós; Fenner, p. 137, pl. 4, fig. 3

2006 Hemiaulus altus Hajós; Davies, p. 238, pl. 5, figs. 5-6 
H. antiquus Jousé 1951 [Fig. 8O-P; Fig. 12H-I]

1951 Hemiaulus antiquus Jousé; Jousé, p. 52, pl. III, figs. 1 a,b

1974 Hemiaulus antiquus Jousé; Strelnikova, p. 101, pl. XLVI, figs. 1-14

1994 Hemiaulus antiquus Jousé; Dell'Agnese and Clark, fig. 3.9

Remarks: Davies (2006) illustrated valves and frustules with a prominent rim developed around the mantle margin, not indicated by type illustrations (Jousé 1951) nor by photographs of Strelnikova (1974).

H. asymmetricus Jousé 1951 [Fig. 8K-L]

1951 Hemiaulus asymmetricus Jousé; Jousé, p. 52, pl. III, fig. 2

1974 Hemiaulus asymmetricus Jousé; Strelnikova, p. 97, pl. XLVII, figs. 1-3

H. curvatulus Strelnikova 1971

1971 Hemiaulus curvatulus Strelnikova; Strelnikova, p. 49, pl. I, figs. 12-13

1974 Hemiaulus curvatulus Strelnikova; Strelnikova, p. 96, pl. XLVII, figs. 14-16

1975 Hemiaulus curvatulus Strelnikova; Hajós and Stradner, p. 931, pl. 6, fig. 8

1988 Hemiaulus curvatulus Strelnikova; Harwood, p. 82, fig. 13.12.

H. echinulatus Jousé 1951 [Fig. 8Q] 
1951 Hemiaulus echinulatus Jousé; Jousé, p. 53, pl. III, figs. 3a-c

1974 Hemiaulus echinulatus Jousé; Strelnikova, p. 100, pl. XLVI, figs. 18-23

1985 Hemiaulus echinulatus Jousé; Fenner, p. 731, fig. 14.10

2002 Hemiaulus echinulatus Jousé; Tapia and Harwood, pl. VII, figs. 7-8

H. elegans (Heiberg) Grunow 1884

1888 Corinna elegans Heiberg; Schmidt et al., pl. 144, figs. 54-55

1974 Hemiaulus elegans (Heiberg) Grunow; Strelnikova, p. 98, pl. XLIV, figs. 11,12, 15

1977 Hemiaulus elegans (Heiberg) Grunow; Ross, Sims and Hasle, p. 186, pl. 7, figs. 45-47

H. hostilis Heiberg sensu Harwood 1988

1988 Hemiaulus hostilis Heiberg; Harwood, p. 82, figs. 14.1-14.5

H. hostilis Heiberg sensu Strelnikova 1974

1974 Hemiaulus hostilis Heiberg; Strelnikova, p. 99, pl. XLVII, figs. 10-13

2006 Hemiaulus hostilis Heiberg; Davies, p. 238, pl. 7, figs. 5-6

H. polymorphus Grunow 1884 [Fig. 9L-M]

1888 Hemiaulus polymorphus Grunow; Schmidt et al., pl. 143, figs. 11-13, 30-34

1977 Hemiaulus polymorphus Grunow; Ross, Sims and Hasle, p. 184, pl. II, figs. 10-12

1991 Hemiaulus polymorphus Grunow; Homann, pl. 24, figs. 1-19 
H. polymorphus var. frigida Grunow 1884

1888 Hemiaulus polymorphus var. frigida Grunow; Schmidt et al., pl. 143, figs. 35-36

1974 Hemiaulus polymorphus var. frigida Grunow; Strelnikova, p. 103, pl. XLV, figs. 1-19

1988 Hemiaulus polymorphus var. frigida Grunow; Harwood, p. 83, fig. 14.7

2001 Hemiaulus polymorphus var. frigida Grunow; Nikolaev et al., p. 20, pl. 24, fig. 6, pl. 25, figs. $1-3$

2002 Hemiaulus polymorphus var. frigida Grunow; Tapia and Harwod, p. 326, pl. V, fig. 8

Hemiaulus sp. cf. H. inaequilaterus Gombos 1976

Description: Typical 'hemiauloid' valves with two transverse folds, two polar elevations, each with three massive linking spines, and a marginal ridge. Conspicuous asymmetry of the valve projections.

Remarks: The valve structure is in part similar to Hemiaulus inaequilaterus Gombos 1976. H. inaequilaterus, besides having an assymetrical valve, exhibits also polar elevations of unequal length. The species reported herein has much more robust cells. Finally, $H$. inaequilaterus is found in sediments of Late Paleocene age (Gombos, 1976), while the discussed species occurs only toward the base of the section (probably Santonian).

H. speciosus Jousé 1951 [Fig. 8G]

1951 Hemiaulus speciosus Jousé; Jousé, p. 55, pl. III, fig. 5

1991 Hemiaulus speciosus Jousé; Fenner, p. 138, pl. 8, figs. 1-3 
H. sporalis Strelnikova 1971 [Fig. 9B-C; Fig. 12K - vegetative cells with semiendogenous resting spores; Fig. 10E - resting spore]

1971 Hemiaulus sporalis Strelnikova; Strelnikova, p. 48, pl. III, figs. 1-10

1974 Hemiaulus sporalis Strelnikova; Strelnikova, p. 95, pl. XLII, figs. 1-11

1988 Hemiaulus sporalis Strelnikova; Harwood, p. 84, figs. 15.7-10

2002 Hemiaulus sporalis Strelnikova; Tapia and Harwood, p. 326, pl. V, fig. 7

Hemiaulus? sp. A [Fig. 9D-E]

Description: Cells heterovalvar, with one 'hemiauloid' valve and one valve resemblant of the genus Anaulus Ehrenberg, that is possessing no polar elevations and two prominent pseudosepta. In both valves the pseudosepta reach only to ca. half of the mantle height. Also in both types of valves, the pseudosepta are associated with a shallow transverse fold on the valve face and in the upper part of the valve mantle, resulting in a pronounced 'chamber'. The 'hemiauloid' valve does not have a marginal ridge, which distinguishes it from the genus Hemiaulus. The nature of terminations of the elevations is unknown. Only single cells observed.

Hemiaulus? sp. B [Fig. 9K]

Description: Valve ca. $35 \mu \mathrm{m}$ long, with flat-terminated elevations (ca. $40 \mu \mathrm{m}$ ) at apices. Central part of the valve slightly elevated. Hyaline marginal ridge. Mantle shallow. The 
nature of the terminations of horns unknown, linking spines not observed or strongly reduced. Only valves seen.

Remarks: Because of the inferred lack of linking spines, the placement in the genus Hemiaulus is tentative.

Genus Hyalodiscus Ehrenberg 1845

H. nobilis Pantocsek 1889 [Fig. 7C-D]

1889 Hyalodiscus nobilis Pantocsek; Pantocsek, pl. XXVI, fig. 374

1974 Hyalodiscus nobilis Pantocsek; Strelnikova, p. 51, pl. II, figs. 3-5

2002 Hyalodiscus nobilis Pantocsek; Makarova et al., p. 19, pl. 13, fig. 7

H. radiatus (O’Meara) Grunow 1879

1974 Hyalodiscus radiatus (O’Meara) Grunow; Gleser et al., pl. XXII, fig. 6

Genus Incisoria Hajós 1975

I. lanceolata Hajós et Stradner 1975 [Fig. 10S-T]

1971 Incisoria lanceolata Hajós et Stradner; Hajós and Stradner, p. 937, pl. 13, figs. 22,25, pl. 36, fig. 6

1988 Incisoria lanceolata Hajós et Stradner; Harwood, p. 84, figs. 12.18, 12.19, 17.4 
Genus Lepidodiscus Witt 1886

L. elegans Witt 1886 [Fig. 6A-B; Fig. 11F]

1886 Lepidodiscus elegans Witt; Witt, p. 28, pl. VII, fig. 6

1886 Lepidodiscus elegans Witt; Schmidt et al., pl. 103, fig. 5

1974 Lepidodiscus elegans Witt; Gleser et al., pl. 8, fig. 4

1974 Lepidodiscus elegans Witt; Ross and Sims, pl. 4, figs. 25-27

1974 Lepidodiscus elegans Witt; Strelnikova, p. 70, pl. XVI, figs. 1-6

1995 Lepidodiscus elegans Witt; Strelnikova, p. 439, figs. 37-40

2008 Lepidodiscus elegans Witt; Strelnikova and Tsoy, p. 73, pl. 90, figs. 1-7, pl. 91, figs.

$1-8$

Genus Medlinia Sims 1998

M. deciusii (Hanna) Nikolaev et Kociolek 2001 [Fig. 9F-H; Fig. 12G]

1927 Trinacria deciusii Hanna; Hanna, p. 36, pl. 5, figs. 3-5

1991 Trinacria deciusii Hanna; Fenner, p. 141, pl. 9, figs. 11-16

2001 Medlinia deciusii (Hanna) Nikolaev et Kociolek; Nikolaev et al., p. 22, pl. 27, figs. 4-6

2002 Triceratium schulzii Jousé; Tapia and Harwood, p. 330, pl. II, figs. 5, 12-13

2006 Medlinia deciusii (Hanna) Nikolaev et Kociolek; Davies, p. 37, pl. 11, figs. 7-8

Remarks: The species is probably confused in the literature with $T$. schulzii Jousé. Tapia and Harwood (2002) illustrated a form which appears to be a certain life stage of M. deciusii, having less internal costae than the form illustrated by Hanna (1927) and in the present paper. 
Fenner (1991) distinguishes T. schulzii from M. deciusii, however the two species need a detailed morphological study to resolve this problem.

M. fenestrata (Witt) Sims 1998 [Fig. 9I]

1886 Triceratium fenestratum Witt; Witt, p. 33, pl. X, fig. 10

1886 Triceratium fenestratum Witt; Schmidt et al., pl. 95, fig. 21, pl. 112, figs. 5-6

1886 Triceratium curvato-vittatum Schmidt; Schmidt et al., pl. 95, figs. 22-26

1889 Triceratium vittatum Pantocsek; Pantocsek, pl. XXI, fig. 318

1935 Triceratium fenestratum Witt; Schulz, pl. I, fig. 7

1974 Triceratium fenestratum Witt; Gleser et al., pl. XV, fig. 1, pl. XVII, fig. 6

1974 Triceratium fenestratum Witt; Strelnikova, pl. XXIX, figs. 18-19

1998 Medlinia fenestrata (Witt) Sims; Sims, p. 356, figs. 45-50, 58, 59

M. weissei (Grunow in Schmidt et al.) Sims 1998 [Fig. 9J]

1984 Sheshukovia weissei (Grunow ex A. Schmidt) Gleser; Gleser, p. 295

1998 Medlinia weissei (Grunow in A. Schmidt) Sims; Sims, pp. 344-347, figs. 15-20, 34-35, $43-44$

Genus Odontotropis Grunow 1884

O. carinata Grunow 1884

1884 Odontotropis carinata Grunow; Grunow, p. 59, pl. V, fig. 58 
1935 Odontotropis carinata Grunow; Schulz, p. 326, pl. II, fig. 10

1959 Odontotropis carinata Grunow; Krotov and Schibkova, p. 121, pl. 4, figs. 1-2

1974 Odontotropis carinata Grunow; Strelnikova, p. 94, pl. XL, figs. 3-7

Remarks: Most frequently present only as isolated spines.

O. cristata Grunow 1884

1884 Odontotropis cristata Grunow; Grunow, p. 59, pl. II, fig. 23

1935 Odontotropis cristata Grunow; Schulz, p. 393, fig. 4

1974 Odontotropis cristata Grunow; Strelnikova, p. 94, pl. XL, figs. 1-2

1994 Odontotropis cristata Grunow; Dell'Agnese and Clark, p. 43, fig. 9.9

Remarks: see $O$. carinata.

Genus Paralia Heiberg 1863

P. crenulata (Grunow) Gleser 1992 [Fig. 7H-I, O-P; Fig. 11E]

1892 Melosira sulcata var. crenulata Grunow; Schmidt et al., pl. 177, figs. 23-26,28

1927 Melosira fausta Schmidt; Hanna, p. 25, pl. 3, fig. 14

1955 Melosira sulcata var. crenulata Grunow; Jousé, p. 83, pl. I, fig. 6

1979 Melosira sulcata f. coronata; Kaczmarska and Kilarski, pl. I, fig. 4

2001 Paralia crenulata (Grunow) Gleser; Nikolaev et al., p. 15, pl. 8, figs. 1-8

2002 Paralia crenulata (Grunow) Gleser; Tapia and Harwood, pl. IV, figs. 14-15 
P. fausta (Schmidt) Sims et Crawford 2002 [Fig. 6G]

1892 Melosira fausta Schmidt; Schmidt et al., pl. 177, figs. 3-10

1974 Melosira fausta Schmidt; Gleser et al., pl. XXXI, fig. 4, pl. XLIV, figs. 10-11

2002 Paralia fausta (Schmidt) Sims et Crawford; Sims and Crawford, p. 368, figs. 18-37

P. ornata (Grunow) Grunow ex van Heurck 1882 [Fig. 6E; Fig. 11D]

1884 Melosira ornata Grunow; Grunow, p. 95, pl. V, figs. 39-40

1892 Melosira ornata Grunow; Schmidt et al., pl. 178, figs. 41,43,45,49

1974 Melosira ornata Grunow; Strelnikova, p. 47, pl. I, figs. 5,6

1991 Paralia ornata Grunow; Homann, pl. 30, figs. 1-6

2002 Paralia ornata Grunow; Tapia and Harwood, pl. I, figs. 3,4

P. sulcata (Ehrenberg) Cleve 1873 [Fig. 6H]

1892 Paralia sulcata (Ehrenberg) Cleve; Schmidt et al., pl. 176, figs. 24-28, 46

1974 Melosira sulcata (Ehrenberg) Kützing var. sulcata; Gleser et al., pl. XII, fig. 1, pl.

XIII, fig. 1

1974 Melosira sulcata (Ehrenberg) Kützing var. sulcata; Strelnikova, p. 49, pl. I, figs. 9-14

1979 Paralia sulcata (Ehrenberg) Cleve; Crawford, pp. 200-209, figs. 1-17

1988 Paralia sulcata (Ehrenberg) Cleve; Harwood, p. 85, figs. 16.8-9

2002 Paralia sulcata (Ehrenberg) Cleve; Tapia and Harwood, p. 328, pl. IX, fig. 13 
Genus Poretzkia Jousé 1949

Poretzkia sp. cf. P. umbonata Gleser 1962 [Fig. 12J]

1974 Poretzkia umbonata Gleser; Gleser et al., pl. XVII, fig. 10

1998 Poretzkia umbonata Gleser; Sims and Mahood, p. 116, figs. 20-25

Genus Proboscia Sundström 1986

P. unicornis Jordan et Ito 1998 [Fig. 10L; Fig. 12F]

1998 Proboscia unicornis Jordan et Ito; Jordan and Ito, p. 316, figs. 29-40

Genus Pseudoaulacodiscus Vekschina 1961

Pseudoaulacodiscus sp. A [Fig. 10I; Fig. 12N-O]

Description: Cells heterovalvar, valves circular, beaked at the poles, epivalve with low polar elevations. Arolae in a central circular patch.

Genus Pseudopodosira Jousé 1949

P. reticulata Strelnikova 1974 [Fig. 6I-J, P]

1974 Pseudopodosira reticulata Strelnikova; Strelnikova, p. 53, pl. III, figs. 2a,b 
P. westii (Smith) Sheshukova-Poretzkaya et Gleser 1964

1990 Pseudopodosira westii (Smith) Sheshukova-Poretzkaya et Gleser; Olshtynskaya, p. 96, pl. 3, figs. $13-15$

Remarks: Harwood (1988) considered $P$. westii from Seymour Island a resting spore. Species of Pseudopodosira are regarded as vegetative cells herein.

Genus Pseudopyxilla Forti 1909

P. aculeata Jousé 1951

1951 Pseudopyxilla aculeata Jousé; Jousé, p. 60, pl. IV, fig. 7

P. americana (Ehrenberg) Forti 1909

1974 Pseudopyxilla americana (Ehrenberg) Forti; Strelnikova, p. 112, pl. LIV, figs. 1-15

Pseudopyxilla sp. A

Description: Cells large, 50-60 $\mu \mathrm{m}$, with a perforate epivalve completely overlapping hyaline hypovalve. No ornamentation.

Pseudopyxilla sp. B 
Description: Cells large, with an ornamented, perforate epivalve completely overlapping and reaching far behind hypovalve. A significant increase in the thickness of the cell wall is observed by mid-height of the cell.

Genus Pterotheca Grunow 1909

P. aculeifera Grunow in Van Heurck 1880-1885 [Fig. 10F-G]

1927 Pterotheca crucifera Hanna; Hanna, p. 30, pl. 4, fig. 5

1988 Pterotheca crucifera Hanna; Harwood, p. 86, fig. 18.5

2001 Pterotheca crucifera Hanna; Nikolaev et al., p. 26, pl. 39, figs. 8-9

2006 Pterotheca crucifera Hanna; Davies, p. 241, pl. 15, fig. 5

2009 Pterotheca aculeifera Grunow; Suto et al., pp. 282-286, pl. 9, figs. 1-47

Remarks: Suto et al. (2009) have evidenced that $P$. crucifera Hanna is a synonym of $P$. aculeifera Grunow.

P. alata Strelnikova 1971 [Fig. 12L]

1971 Pterotheca alata Strelnikova; Strelnikova, p. 49, pl. II, figs. 5-7

1974 Pterotheca alata Strelnikova; Strelnikova, p. 113, pl. LVI, figs. 16-17

1991 Pterotheca alata Strelnikova; Homann, p. 136, pl. 53, figs. 24,25, 30-32

P. clavata Strelnikova 1974 [Fig. 10X] 
1974 Pterotheca clavata Strelnikova; Strelnikova, p. 115, pl. LVII, fig. 35

P. evermanni Hanna 1927 [Fig. 10A-B]

1927 Pterotheca evermanni Hanna; Hanna, p. 31, pl. 4, fig. 6

1974 Pterotheca evermanni Hanna; Gleser et al., pl. XII, fig. 4

1974 Pterotheca evermanni Hanna; Strelnikova, p. 112, pl. LVI, figs. 12-15

1988 Pterotheca evermanni Hanna; Harwood, p. 86, figs. 18.13-14

1991 Pterotheca evermanni Hanna; Fenner, p. 139, pl. 2, fig. 13

1991 Pterotheca evermanni Hanna; Homann, p. 137, pl. 53, figs. 21-23

P. simplex Strelnikova 1971

1971 Pterotheca simplex Strelnikova; Strelnikova, p. 50, pl. I, fig. 17-18

1974 Pterotheca simplex Strelnikova; Strelnikova, p. 115, pl. LVII, figs. 31-32

Pterotheca sp. A [Fig. 10V-W]

Description: Only cylindrical, hyaline epivalves to $15 \mu \mathrm{m}$ seen, with a small rim surrounding the valve face.

'Pterotheca? sp.' Strelnikova 1974 [Fig. 10C-D; Fig. 12M]

1974 Pterotheca? sp. Strelnikova; Strelnikova, p. 116, pl. LVII, figs. 33-34 
1985 Pterotheca? sp. Strelnikova; Barron, p. 139, pl. 10.2, fig. 11

2006 Pterotheca? sp. Strelnikova; Davies, p. 241, pl. 15, fig. 6

Genus Pyrgodiscus Kitton 1885

P. triangulatus Hajós et Stradner 1975 [Fig. 7L]

1975 Pyrgodiscus triangulatus Hajós et Stradner; Hajós and Stradner, p. 928, figs. 11a,b, pl. 18, figs. 5,6

1988 Pyrgodiscus triangulatus Hajós et Stradner; Harwood, p. 87, figs. 19.6-7

Remarks: Sims (1988) listed P. triangulatus as a possible synonym of Sceletonema polychaetum of Strelnikova (1974), subsequently transferred to the genus Trochosira (Sims 1988) and Trochosiropsis (Tapia and Harwood 2002). Harwood (1988) considered the discussed species a resting spore. The status of $P$. triangulatus as a distinct species is confirmed herein.

Genus Rhizosolenia Brightwell

R. dubia (Grunow) Homann 1991

1991 Rhizosolenia dubia (Grunow) Homann; Homann, p. 69, pl. 35, fig. 8

Genus Sceptroneis Ehrenberg 1844 
S. dimorpha Strelnikova 1974 [Fig. 10O-R]

1974 Sceptroneis dimorpha Strelnikova; Strelnikova, p. 110, pl. LIV, figs. 18-30

2006 'Sceptroneis dimorpha' Strelnikova; Sims et al., p. 383, figs. 61-65

Sceptroneis sp. cf. S. gracilis Hajós 1975 [Fig. 10M-N]

1975 Sceptroneis gracilis Hajós; Hajós and Stradner, p. 936, fig. 19

Remarks: No intact valves seen.

Genus Sheshukovia Gleser 1984

S. excavata (Heiberg) Nikolaev et Harwood 2001 [Fig. 9N]

1886 Trinacria excavata Heiberg; Schmidt et al., pl. 96, figs. 6-8, pl. 97, figs. 6-10

1974 Triceratium excavatum (Heiberg) Strelnikova; Strelnikova, p. 82, pl. XXXI, figs. 8-14

1975 Trinacria excavata Heiberg; Hajós and Stradner, p. 932, pl. 10, fig. 1

1977 Trinacria excavata Heiberg; Ross, Sims and Hasle, p. 195, pl. 8, figs. 53-54

1988 Trinacria excavata Heiberg; Harwood, p. 89, figs. 21.15-16

1991 Trinacria excavata Heiberg; Homann, p. 119, pl. 46, figs. 1-8, pl. 47, figs. 1-6

2001 Sheshukovia excavata (Heiberg) Nikolaev et Harwood; Nikolaev et al., p. 21, pl. 29, figs. $1-5$ 
S. hemiauloides Sims 1986

1986 Sphynctolethus hemiauloides Sims; Sims, p. 246, figs. 16-22, 64-65

1991 Sphynctolethus hemiauloides Sims; Fenner, p. 140, pl. 4, figs. 2,4

Genus Stellarima Hasle et Sims 1986

S. steinyi (Hanna) Hasle et Sims 1987 [Fig. 10U]

1927 Coscinodiscus steinyi Hanna; Hanna, p. 19, pl. 2, fig. 5-6

1974 Coscinodiscus symbolophorus Grunow; Strelnikova, p. 63, pl. XII, figs. 1-7

1987 Stellarima steinyi (Hanna) Hasle et Sims; Sims and Hasle, p. 230, figs. 8-18, 29-31

1988 Stellarima steinyi (Hanna) Hasle et Sims; Harwood, p. 88, figs. 20.3-4

2001 Stellarima steinyi (Hanna) Hasle et Sims; Nikolaev et al., p. 18, pl. 20, figs. 1-6

2002 Stellarima steinyi (Hanna) Hasle et Sims; Tapia and Harwood, p. 328, pl. VII, fig. 2

2006 Stellarima steinyi (Hanna) Hasle et Sims; Davies, p. 26, pl. 4, figs. 7-8

Genus Stephanopyxis (Ehrenberg) Ehrenberg 1845

S. barbadensis (Greville) Grunow 1884

1865 Crasswelia barbadensis Greville; Greville, XIV, p. 3, pl. I, fig. 11

1888 Stephanopyxis barbadensis (Greville) Grunow; Schmidt et al., pl. 130, figs. 6-10

1974 Stephanopyxis barbadensis (Greville) Grunow; Strelnikova, p. 58, pl. VI, figs. 1-8 
1994 Stephanopyxis barbadensis (Greville) Grunow; Dell'Agnese and Clark, p. 43, figs. $10.7-8$

S. dissonus (Schulz) Strelnikova et Nikolaev 1988 [Fig. 11G]

1949 Coscinodiscus dissonus Schulz; Jousé, p. 72, pl. II, fig. 1

1974 Coscinodiscus dissonus Schulz; Strelnikova, p. 61, pl. VIII, figs. 14-15

1988 Pyxidicula dissona (Schulz) Strelnikova et Nikolaev; Gleser et al., p. 41, pl. 22, figs.

$1-8$

2002 Stephanopyxis dissonus (Schulz) Strelnikova et Nikolaev; Tapia and Harwood, p. 328, pl. VI, figs. 1-3

S. grunowii Grove et Sturt 1888 [Fig. 11H]

1888 Stephanopyxis grunowii Grove et Sturt; Schmidt et al., pl. 130, figs. 1-5

1927 Stephanopyxis grunowii Grove et Sturt; Hanna, pp. 33-34, pl. 4, fig. 12

1955 Stephanopyxis grunowii Grove et Sturt; Jousé, p. 85, pl. II, figs. 1-4

2001 Stephanopyxis grunowii Grove et Sturt; Nikolaev et al., p. 14, pl. 7, figs. 1-4

2002 Stephanopyxis grunowii Grove et Sturt; Tapia and Harwood, p. 328, pl. VII, fig. 5

Genus Thalassiosiropsidella Nikolaev et Harwood 2007

T. simsii Nikolaev et Harwood 2007 
2007 Thalassiosiropsidella simsii Nikolaev et Harwood; Nikolaev and Harwood, pp. 65-67, pl. 3, figs. 1-5

Genus Thalassiosiropsis Hasle 1985

T. wittiana (Pantocsek) Hasle 1985 [Fig. 11B]

1985 Thalassiosiropsis wittiana (Pantocsek) Hasle; Hasle and Syvertsen, pp. 82-91, figs. 141

1988 Thalassiosiropsis wittiana (Pantocsek) Hasle; Gleser et al., pl. XXXIII, figs. 1-9

1988 Thalassiosiropsis wittiana (Pantocsek) Hasle; Harwood, p. 89, fig. 20.6

1991 Thalassiosiropsis wittiana (Pantocsek) Hasle; Homann, pl. 37, figs. 8-10

1994 Thalassiosiropsis wittiana (Pantocsek) Hasle; Dell'Agnese and Clark, pl. 10, fig. 9

2001 Thalassiosiropsis wittiana (Pantocsek) Hasle; Nikolaev et al., p. 12, pl. I, figs. 1-4

2002 Thalassiosiropsis wittiana (Pantocsek) Hasle; Tapia and Harwood, pl. IV, fig. 13

2006 Thalassiosiropsis wittiana (Pantocsek) Hasle; Davies, p. 16, pl. 1, figs. 1-2

Genus Trinacria Heiberg 1863

T. indefinita Jousé 1951 [Fig. 8I-J]

1951 Trinacria indefinita Jousé; Jousé, p. 50, pl. II, figs. 5 a-c

1974 Triceratium indefinitum (Jousé) Strelnikova; Gleser et al., pl. XI, fig. 5

1974 Triceratium indefinitum (Jousé) Strelnikova; Strelnikova, p. 82, pl. XXX, figs. 1-17

1988 Trinacria indefinita Jousé; Sims and Ross, pl. 7, fig. 49 
2002 Trinacria indefinita Jousé; Tapia and Harwood, p. 330, pl. IV, figs. 1-2,5-6

Genus Trochosiropsis Gleser 1984

T. polychaeta (Strelnikova) Tapia 2002 [Fig. 7J-K]

1971 Sceletonema polychaeta Strelnikova; Strelnikova, p. 42, pl. I, figs. 3-5

1974 Skeletonema polychaetum Strelnikova; Strelnikova, p. 54, pl. III, figs. 3-7

1985 Skeletonema polychaetum Strelnikova; Barron, p. 141, pl. 10.1, figs. 2-4

1988 Skeletonema polychaetum Strelnikova; Harwood, p. 88, figs.16.14-15

1988 Trochosira polychaeta (Strelnikova) Sims; Sims, p. 251, figs. 15-21, 29-34

1994 Skeletonema polychaetum Strelnikova; Dell'Agnese and Clark, p. 38, pl. 4, fig. 7

2002 Trochosiropsis polychaeta (Strelnikova) Tapia; Tapia and Harwood, p. 330, pl. VIII, figs. 3-4

2006 Trochosiropsis polychaeta (Strelnikova) Tapia; Davies, p. 22, fig. 3.2, pl. 3, figs. 7-8

Remarks: See discussion on Pyrgodiscus triangulatus Hajós et Stradner.

Genus Truania Pantocsek 1886

T. archangelskiana Pantocsek 1886 [Fig. 6F; Fig. 11I]

1892 Melosira asiatica Brun; Schmidt et al., pl. 179, fig. 6

1886 Truania archangelskiana Pantocsek; Pantocsek, pl. XX, fig. 178

1892 Truania archangelskiana Pantocsek; Schmidt et al., pl. 173, fig. 6 
1974 Truania archangelskiana Pantocsek; Strelnikova, p. 50, pl. I, figs. 1-2

2007 Truania archangelskiana Pantocsek; Sims and Crawford, pp. 197-207, figs. 1-24

2008 Truania; Crawford and Sims, pl. 3, fig. 15

Remarks: The present study is the second record of $T$. archangelskiana outside Russia (Sims and Crawford 2007).

Unknown genus and species \#1 [Fig. 13F-H]

Decription: Frustules connected in ribbon-like chains. Elongate, bipolar lanceolate valves with a low oval to elliptical elevation in the center and two long projections. Valve face undulate. A single rimoportule next to the valve center. 3-7 rings of wedge-shaped bosses on the valve face.

Remarks: A few morphotypes of this species were found, differing with respect to the arrangement of areolae on the valve face.

Unknown genus and species \#2 [Fig. 13E]

Description: Valves circular, flat or weakly domed, with a central rimoportule associated with a curved hyaline ray extending from the valve center to near the margin.

Unknown genus and species \#3 [Fig. 13A-B]

Description: Valves large, circular, highly domed, with a large central rimoportule. Areolae in radial rows interrupted by numerous solid spines. 
Unknown genus and species \#4 [Fig. 13C-D]

Description: Valves oval to elliptical, mostly hyaline, with prominent polar elevations terminated in pseudocelli.

\section{References}

Crawford, R.M., 1979. Taxonomy and frustular structure of the marine centric diatom Paralia sulcata. Journal of Phycology 15, 200-210.

Davies, A., 2006. High resolution palaeoceanography and palaeoclimatology from mid and high latitude Late Cretaceous laminated sediments. Unpublished PhD thesis, University of Southampton, School of Ocean and Earth Science.

Dell'Agnese, D.J., Clark, D.L., 1994. Siliceous microfossils from the warm late Cretaceous and early Cenozoic Arctic Ocean. Journal of Paleontology 68, 31-47.

Fenner, J.M., 1985. Late Cretaceous to Oligocene planktic diatoms, in: Bolli, H.M., Saunders, J.B., Perch-Nielsen, K. (Eds.), Plankton stratigraphy, vol. 2. Cambridge, pp. $713-762$.

Fenner, J.M., 1991. Taxonomy, stratigraphy, and paleoceanographic implications of Paleocene diatoms, in: Ciesielski, P.F., Kristoffersen, Y. et al. (Eds.), Proceedings of the Ocean Drilling Program, Scientific Results, 114. College Station, TX (Ocean Drilling Program), pp. 123-154.

Forti, A., Schulz, P., 1932. Erste Mitteilung über Diatomeen aus dem hannoverschen Gault. Beihefte zum Botanischen Centralblatt 50, 241-246 (in German).

Fourtanier, E., Kociolek, J.P., 2007-2010. Catalogue of Diatom Names. California Academy of Sciences (http://researcharchive.calacademy.org/research/diatoms/names/ as of June 2010). 
Gersonde, R., Harwood, D.M., 1990. Lower Cretaceous diatoms from ODP Leg 113 Site 693

(Weddell Sea). Part 1: Vegetative cells, in: Barker, P.F., Kennett, J.P. et al.

(Eds.), Proceedings of the Ocean Drilling Program, Scientific Results, 113.

College Station, TX (Ocean Drilling Program), pp. 365-402.

Gleser, S.I., 1984. Significance of research on the systematics of diatoms for biostratigraphy and paleogeography. In: Ezhegodnik Vsyesoyuznogo Paleontologicheskogo Obshchestva 27, 284-298 (in Russian).

Gleser, S.I., Jouse, A.P., Makarova, I.B., Proshkina-Lavrenko, A.I., Sheshukova- Poretzkaya, V.S., 1974. Diatoms of the USSR: Fossil and Recent, vol. 1. Nauka, Moskva (in Russian).

Gleser, S.I., Makarova, I.V., Moiseeva, A.I., Nikolaev, V.A., 1988. Diatoms of the USSR:

Fossil and Recent, vol. 2, fasc. 1. Nauka, Moskva (in Russian).

Gombos, A. M., Jr., 1976. Paleogene and Neogene diatoms from the Falkland Plateau and Malvinas Outer Basin: Leg 36, Deep Sea Drilling Project, in: Barker, P.F., Dalziel, I.W.D. et al. (Eds.), Initial Reports of the Deep Sea Drilling Project, 36. U.S. Government Printing Office, Washington, pp. 575-688.

Greville, R.K., 1865. Descriptions of new and rare diatoms. Series XIV. Transactions of the Microscopic Society of London. New Series 13, 1-10.

Greville, R.K. 1865. Descriptions of new and rare diatoms. Series XV. Transactions of the Microscopic Society of London. New Series 13, 24-37.

Grunow, A., 1884. Die Diatomeen von Franz-Josefs Land. Denkschriften der mathematischnaturwissenshaftlichen Classe der Kaiserlichen Akademie der Wissenschaften, 48, 53-112 (in German).

Harwood, D.M., Gersonde, R., 1990. Lower Cretaceous diatoms from ODP Leg 113 site 693 (Weddell Sea). Part 2: Resting spores, chrysophycean cysts, and endoskeletal 
dinoflagellate, and notes on the origin of diatoms, in: Barker, P.F., Kennett, J.P. et al. (Eds.), Proceedings of the Ocean Drilling Program, Scientific Results, 113. College Station, TX (Ocean Drilling Program), pp. 403-425

Hasle, G.R., Sims, P.A., 1986. The diatom genera Stellarima and Symbolophora, with comments on the genus Actinoptychus. British Phycological Journal 21, 97114.

Hasle, G.R., Syvertsen, E.E., 1985. Thalassiosiropsis, a new diatom genus from the fossil record. Micropaleontology 31, 82-91.

Hendey, N.I., 1993. Observations on Gladiopsis from the Moreno Shale, California. Nova Hedwigia Beiheft 106, 269-273.

Homann, M., 1991. Die Diatomeen der Fur-Formation (Alttertiär) aus dem Limfjord-Gebiet, Nordjütland/Dänemark. Geologisches Jahrbuch Reihe A, Heft 123, Schweizerbart, Stuttgart.

Jordan, R.W., Ito, R., 2002. Observations on Proboscia species from Late Cretaceous sediments, and their possible evolution from Kreagra, in: John, J. (Ed.), Proceedings of the 15th International Diatom Symposium. A.R.G. Gantner Verlag K.G., Ruggell / Liechtenstein, pp. 313-329.

Jousé, A.P., 1949. Algae diatomaceae aetatis supernecretaceae ex arenis argillaceis systematis fluminis Bolschoy Aktay in declivitate Orientali Ural Borealis. Botanicheskye material'y otdela sporov'ykh rasteniï 6, 65-78 (in Russian).

Jousé, A.P., 1951. Diatomeae et silicoflagellatae aetatis Cretae Superne e montibus Uralensibus Septentrionalibus. Botanicheskye material'y otdela sporov'ykh rasteniï 7, 42-65 (in Russian). 
Jousé, A.P., 1955. Species novae generis Gladius Schulz in stratura aetatis Cretaceae superioris. Botanicheskye material'y otdela sporov'ykh rasteniï10, $72-76$ (in Russian).

Kaczmarska, I., Kilarski, W., 1979. Budowa pancerzyków Melosira sulcata (Ehr.) Kutz. var. sulcata z dolnooligoceńskich diatomitów z Futomy (Karpaty, Polska). Rocznik Polskiego Towarzystwa Geologicznego 49, 185-194 (in Polish).

Krotov, A.I., Schibkova K.G., 1959. Species novae diatomacearum e sedimentis Cretae superioris in mintibus Uralensibus. Botanicheskye material'y otdela sporov'yh rasteniï12, 112-129 (in Russian).

Makarova, I.V., Strelnikova, N.I., Kozirenko, T.F., 2002. The diatoms of Russia and adjacent countries. Fossil and recent, vol. II, fasc. 3. St. Petersburg University Press, St. Petersburg (in Russian).

Nikolaev, V.A., Harwood, D.M., 2007. New taxa of extinct diatoms (Bacillariophyta) from Antarctic. Novosti sistematiki nizshikh rasteniï 41, 59-69 (in Russian).

Nikolaev, V.A., Harwood, D.M., Samsonov, N.I., 2001. Early Cretaceous diatoms. Nauka, St. Petersburg (in Russian).

Nikolaev, V.A., Kociolek, J.P., Fourtanier, E., Barron, J.A., Harwood, D.M., 2001. Late Cretaceous diatoms (Bacillariophyceae) from the Marca Shale member of the Moreno Formation, California. Occasional Papers of the California Academy of Sciences 152, 1-89.

Olshtynskaya, A., 1990. Morphology of the diatom genus Pseudopodosira, in: Simola, H. (Ed.), Proceedings of the Tenth International Diatom Symposium. Koeltz Scientific Books, Koenigstein, pp. 93-103.

Pantocsek, J., 1886. Beiträge zur Kenntnis der Fossilen Bacillarien Ungarns. I. Theil: Marine Bacillarien. Platzko, J., Nagy-Tapolcsány (in German). 
Pantocsek, J., 1889. Beiträge zur Kenntnis der Fossilen Bacillarien Ungarns. II Theil:

Brackwasser Bacillarien. Platzko, J., Nagy-Tapolcsány (in German).

Ross, R., Sims, P.A., 1974. Observations on family and generic limits in the Centrales, in:

Simonsen, R. (Ed.), Second Symposium on Recent and Fossil Diatoms. Nova Hedwigia Beiheft 45, pp. 97-121.

Ross, R., Sims, P.A., 1985. Some genera of the Biddulphiaceae (diatoms) with interlocking linking spines. Bulletin of the British Museum (Natural History), Botany Series $13,277-381$.

Ross, R., Sims, P.A., Hasle, G.R., 1977. Observations on some species of the Hemiauloideae, in: Simonsen, R. (Ed.), Fourth Symposium on Recent and Fossil Diatoms. Nova Hedwigia Beiheft 54, 179-213.

Schmidt, A., Schmidt, M., Fricke, F., Heiden, H., Müller, O., Hustedt, F., 1874-1959. Atlas der Diatomaceen-kunde. Leipzig-Berling. Reprint 1984, Koeltz Scientific Books, Koenigstein (in German).

Schulz, P., 1935. Diatomeen aus senon Schwammgesteinen der Danziger Bucht. Zaugleich ein Beitrag zur Entwicklungsgeschichte der Diatomeen. Botanisches Archiv 37, 383-414 (in German).

Sims, P.A., 1986. Sphynctolethus Hanna, Ailuretta gen. nov., and evolutionary trends within the Hemiauloideae. Diatom Research 1, 241-269.

Sims, P.A., 1988. The fossil genus Trochosira, its morphology, taxonomy and systematics.

Diatom Research 3, 245-257.

Sims, P.A., 1994. Benetorus, Gladiopsis and related genera from the Cretaceous. Diatom Research 9, 165-187.

Sims, P.A., 1998. The early history of the Biddulphiales. I. The genus Medlinia gen. nov. Diatom Research 13, 337-374. 
Sims, P.A., Crawford, R.M., 2002. The morphology and taxonomy of the marine centric diatom genus Paralia. II. Paralia crenulata, $P$. fausta and the new species, $P$. hendeyi. Diatom Research 17, 363-382.

Sims, P.A., Crawford, R.M., 2007. The fossil diatom genus Truania Pantocsek and its relationship with Ellerbeckia Crawford. Diatom Research 22, 195-207.

Sims, P.A., Hasle, G.R., 1987. Two Cretaceous Stellarima species: S. steinyi and S. distincta; their morphology, palaeogeography and phylogeny. Diatom Research 2, 229240.

Sims, P.A., Mahood, A.D., 1998. Vulcanella hannae Sims and Mahood, gen. et sp. nov., with a discussion of the genera Tumulopsis Hendey, Acanthodiscus Pantocsek, Poretzkia Jousé and Goniothecium Ehrenberg. Diatom Research 13, 113-131.

Sims, P.A., Ross, R., 1988. Some Cretaceous and Palaeogene Trinacria (diatom) species. Bulletin of the British Museum (Natural History), Botany series 18, 275-322.

Sims, P.A., Mann, D.G., Medlin, L.K., 2006. Evolution of the diatoms: insights from fossil, biological and molecular data. Phycologia 45, 361-402.

Strelnikova, N.I., 1966. Revisio specierum generum Gladius Schulz et Pyxilla Grev. (Bacillariophyta) e sedimentis Cretae superioris. Novosti sistematiki nizshikh rastenii, 23-36 (in Russian).

Strelnikova, N.I., 1971. Species novae bacillariophytorum e sedimentis Cretae posterioris in declivitate orientali partis polaris ac praepolaris montium Uralensium. Novosti sistematiki nizshikh rasteniï 8, 41-50 (in Russian).

Strelnikova, N.I., 1974. Diatomei pozdnego mela. Nauka, Moskva (in Russian).

Strelnikova, N.I., 1995. Actinoptychus Ehrenberg and kindred genera in Cretaceous and Paleogene deposits, in: Marino, D., Montresor, M. (Eds.), Proceedings of the Thirteenth International Diatom Symposium. Biopress Ltd, Bristol, pp. 431-442. 
Strelnikova, N.I., Fourtanier, E., Kociolek, J.P., 2004. Morphological studies of Aulacodiscus species from the "Russian Collecion" of the California Academy of Sciences. Diatom Research 19, 283-310.

Strelnikova, N.I., Tsoy, I.B., 2008. The diatoms of Russia and adjacent countries, fossil and recent, vol. II, fasc. 5. St. Peterburg University Press, St. Petersburg (in Russian).

Suto, I., Jordan, R.W., Watanabe, M., 2009. Taxonomy of middle Eocene diatom resting spores and their allied taxa from the central Arctic Basin. Micropaleontology $55,259-312$.

Tapia, P.M., Harwood, D.M., 2002. Upper Cretaceous diatom biostratigraphy of the Arctic archipelago and northern continental margin, Canada. Micropaleontology 48, $303-342$.

Witt, O. N., 1886. Ueber den Polierschierfer von Archangelsk-Kurojedowo im Gouv. Simbirsk. Verhandlungen der Russisch-kaiserlichen mineralogischen Gesselschaft zu St. Petersburg. Serie II, 22, 137-177 (in German). 